\title{
Understanding Boko Haram
}

Daniel Flynn

DePaul University, FLYNN.D7@GMAIL.coM

Follow this and additional works at: https://via.library.depaul.edu/etd

\section{Recommended Citation}

Flynn, Daniel, "Understanding Boko Haram" (2017). College of Liberal Arts \& Social Sciences Theses and Dissertations. 223.

https://via.library.depaul.edu/etd/223

This Thesis is brought to you for free and open access by the College of Liberal Arts and Social Sciences at Digital Commons@DePaul. It has been accepted for inclusion in College of Liberal Arts \& Social Sciences Theses and Dissertations by an authorized administrator of Digital Commons@DePaul. For more information, please contact digitalservices@depaul.edu. 


\title{
UNDERSTANDING BOKO HARAM
}

\author{
A Thesis \\ Presented in \\ Partial Fulfillment of the \\ Requirements for the Degree of \\ Master of Arts
}

March 2017

BY

Daniel Flynn

Department of International Studies

College of Liberal Arts and Social Sciences

DePaul University

Chicago, Illinois 


\section{Acknowledgements}

I would never have been able to complete this project on my own. Thanks go to more people than there is space to name. But there are a few who deserve special recognition. Thank you:

To my advisor, Dr. Heidi Nast, for helping to shape the project, providing countless edits and revisions, and providing two years worth of guidance and support, and to my committee members, Dr. Clement Adibe and Dr. Kalyani Menon.

To my parents, Patrick and Kathleen, and to Ryan, Emily, Caitlin, and Shane (and Finley), for continuing to believe in and be proud of me, no matter how long it took to get this done.

And to Kristin, for, well, everything. 


\section{Contents:}

Introduction -4

Chapter 1

Framing Boko Haram in the scholarly literature -12

Chapter 2

The foundations of an ideology -28

Chapter 3

The explosive contours of Boko Haram - 58

Chapter 4

State failure and the geographic, political, socioeconomic, and transnational factors involved in the insurgency -98

Conclusion

The fight for the future -131

Appendix A

Timeline of major events of the Boko Haram insurgency - 136

Bibliography - 141 


\section{Introduction}

In March 2014, the looming fear of Boko Haram forced the Nigerian government, with the safety of students in mind, to close all schools in Borno State in the country's northeastern corner (Topol 2014). Shortly after the closure, however, the Government Secondary School in Chibok — a small town in Borno, unusual in that a majority of its population was Christian in the Muslimdominant northern region (Nossiter 2014) — reopened for seniors who needed to complete their exams in order to be eligible to continue on to university. More than 300 girls returned to the school, studying during the day and boarding in the dormitories at night, living through each sweltering moment terrified of the militants that had been waging a violent insurgency across the region since 2009. On the night of April 14-15, their fears were realized.

Shortly before midnight, trucks rumbled out of the darkness and dozens of men in the uniforms of the Nigerian military swept into the campus. It quickly became clear that these were not government soldiers. Firing rifles into the air, they began rounding up the girls, telling them "If you want to die, sit here. We will kill you. If you don't want to die, you will enter the trucks" (Nossiter 2014). Some of the girls managed to disappear into the bush while others leapt from the trucks as they drove away. Although 53 of the girls were able to avoid capture that night, more than 260 were kidnapped. The incident was widely reported by media outlets around the world, and the story spread quickly via a Twitter campaign raising awareness through the hashtag "Bring Back Our Girls.” It was not until this incident that Boko Haram and its insurgency gained significant international notoriety and infamy. But the awareness that was raised eventually dissipated and the outcry, unsurprisingly, went unheard by the members of Boko Haram.

In the media coverage that followed the Chibok kidnapping, many of the attempts to explain Boko Haram, to understand why they would kidnap more than 260 girls and wage war against government forces and civilians alike, focused on the etymology of its name - translated as "Western 
education is forbidden" — and their so-called Islamic extremism. But there is far more to Boko Haram and the motivations behind its insurgency than religious zealotry and hatred for Western education. Even just encapsulated within the kidnapping in Chibok are a number factors that must be evaluated and which make the situation far more complicated than just an ideological attack on the propagation of Western education.

That the girls were receiving a Western education certainly played a role in prompting the raid. Likewise the fact that Chibok is a Christian-majority village, a rarity in the region, presented an opportunity for Boko Haram to force its ideology upon Christians. There is the fact that with families who were able to afford to put their daughters through to the end of secondary school, many of the girls were likely from a different socioeconomic class than the average member of Boko Haram. There is also the obvious gender component: it is likely that Boko Haram targeted the school because it presented the opportunity to kidnap young women en masse and, thus, the opportunity to provide "brides" to its soldiers. There is the geographic factor of Boko Haram being able to carry out this raid, kidnap scores of young women, and disappear into the bush. And there is the reality of the state's failure, first in declaring that it was too dangerous for schools to remain open but failing to offer any sort of protection, and second, in the fact that state forces knew of the impending raid at least four hours before it took place but failed to deploy enough troops to stop it, possibly because of a lack of resources and soldiers who were too unequipped - and, as a result, afraid - to repel the attack (Amnesty International 2014). All of these factors must be considered if one is to understand what happened in Chibok. And all of these factors - evident in varying degrees in every aspect of the crisis - must be examined on a much larger scale if one is to understand Boko Haram and its insurgency.

The foundations of the crisis can and should be traced back over centuries. The factors that helped create the ideological, psychological, and physical space that allowed for the existence of 
Boko Haram include the religious but, equally importantly, include the historical, political, geographical, and socioeconomic as well. To place the primary focus for the group's motivations on radical Islam is to limit one's understanding of the crisis and of the members of Boko Haram. It is to argue that because they are acting in the name of their religious beliefs, they are outside the realm of logic, impossible to be reasoned with, and directly opposed to anyone who believes in the liberal democratic state and its ideas of secular modernity. But Boko Haram did not begin as a violent insurgency; it was not originally founded to wage war.

Thus, the hypothesis of this project is that viewing Boko Haram primarily through the lens of Islamic extremism overemphasizes the present religious reality of the group while downplaying the complicated historical religious contexts that allowed such an ideology to gain relevance and authority, and ignoring the critical geographical, political, and socioeconomic factors that have been no less important in creating the space in which Boko Haram could exist and succeed. It is equally critical to recognize the Nigerian state's responsibility for creating and exacerbating the crisis by acting with impunity, avoiding meaningful action intended to rectify the issues at the root of the crisis, and enacting and justifying its own brand of violence. Part of the purpose of this project is to demonstrate that some measure of blame lies with the Nigerian state, as it does with the colonial authorities. And part of the purpose of this project is to provide documentation of Boko Haram's attacks, raids, and kidnappings even as they seem to have ceased commanding the level of international attention they did after the events of April 2014. In seeking to demonstrate this hypothesis and fulfill this purpose, two main questions must be answered: Why has Boko Haram transitioned from a localized, grassroots organization into the wide-ranging militant organization it is today? And how did Boko Haram come to be afforded the ideological and physical space in which it could carry out such an insurgency? This project will demonstrate the hypothesis and answer these questions over the course of four chapters, outlined below. 
Chapter 1, entitled "Framing Boko Haram in the scholarly literature," provides an overview of the field of study and the ways in which some of the scholars in the field have sought to explain the crisis in northern Nigeria. There are two modes of understanding and explanation that are primarily used, often separately but at times in conjunction. First is, as mentioned previously, to frame Boko Haram and its insurgency in terms of religious extremism and radical Islam. These studies focus largely on the ideological motivators behind the insurgency, examining the religious fundamentalism of the members and leaders of the group and finding as a foundational component of the insurgency the idea of religious violence. This section discusses definitions of fundamentalism and extremism and examines the concepts of jihad and terrorism. Ultimately, this section details the problematic effect of framing conflicts like that with Boko Haram in terms of religious violence, specifically that it otherizes the combatants and distinguishes their violence as a different, and worse, type of violence than that enacted by the state.

Second are the concomitant theories of relative deprivation and frustration-aggression. Both of these theories focus more on the socioeconomic motivators behind the insurgency, finding its root causes in economic inequality (whether real or only perceived), which fosters a sense of frustration that subsequently leads to violence. That there is economic imbalance that exists along a number of different dividing lines in Nigeria is a fact, demonstrated by some of the statistics provided in this section. But again, this approach is problematic in what it elides, specifically that Boko Haram would have come to exist solely as a result of socioeconomic deprivation and the resultant sense of frustration. Finally, this chapter will explain where this project seeks to exist within the presently constituted field of study, namely as an examination of all the factors - religious, socioeconomic, psychological, geographical, historical, and political — precipitating the rise to Boko Haram that provides a more thorough and holistic understand of the group than those which currently exist. 
Chapter 2 — "The foundations of an ideology" — begins the task of constructing such an understanding. This chapter focuses on the religious contexts into which Boko Haram came to exist. Beginning with the introduction of Islam into the region that would become northern Nigeria in the 11 th century and the foundation of the Sokoto Caliphate, the structure of authority that would be used by the British as a means of indirect rule after its conquest, the chapter then moves forward into more modern times. Examining the geographical specificity of Islam and Christianity during the colonial period, along with a deepening attachment among all Nigerians to a religious identity rather than a tribal or ethnic one, gives a sense of how religion, and these two in particular, has come to be so fundamentally important to Nigerians and to the historical trajectory and geographical fault lines of the state. The importance of religion and religious identity is critical to understanding how Boko Haram could amass such a following, and the differences in the nature of religion and tolerance between Nigeria's northern and southern regions is critical to understanding why Boko Haram came to exist where it did.

There are also historical patterns and expressions of dissent and discourse among Muslims of northern Nigeria that must be incorporated into an analysis of Boko Haram because their echoes can be heard throughout the development of the present insurgency. Finally, political Islam has been important to the development of the ideology of Boko Haram. Heavily influenced by the medieval scholar Ibn Taymiyya, political Islam comes into effect in its ability to provide a total way of life for its adherents, a moral, spiritual, and political guidebook. For the leaders of Boko Haram, this meant an alternative to the secular state and a rationale behind their stated goal of establishing an Islamic one. Although there is a significant amount of discussion and debate surrounding political Islam, some of which is described in Chapter 2, it remains critical to understanding Boko Haram and the ideology behind the insurgency. 
The third chapter, "The explosive contours of Boko Haram," details how the group developed under Muhammed Yusuf and Abubakar Shekau. After outlining the geographical range of the insurgency and hotspots within the conflict, this chapter examines a number of similarly-minded antecedent groups with which Muhammed Yusuf, the founder and original leader of Boko Haram, may have been associated. In examining his possible connections with these groups, the more recent foundations of Boko Haram's original ideologies can be seen. Yusuf gained influence through his work and affiliation with some of these other groups and became well-known enough that his followers began to be referred to as the Yusufiyyah, or the followers of Yusuf. This group would later become Boko Haram. Before Yusuf's death and the transformation into Boko Haram, the group provided social services that the state did not, engendering a sense of popular support among many people in the northern region. The insurgency only began in earnest when Abubakar Shekau arose as the next leader of Boko Haram.

After documenting the developments of Boko Haram under each of its two principal leaders (though now it could be argued that there have been three as the group seems to have fractured in recent months, a development detailed further in this chapter), I discuss the recruits and members of Boko Haram. These are primarily the almajiri, boys and young men from rural villages sent to Maiduguri and other northern cities for Islamic education, among other reasons. I also discuss some of the politicians and elites who have supported Boko Haram financially as well as international connections between Boko Haram and other similar groups. Finally, this chapter analyzes Boko Haram's attacks and confrontations with state forces, outlining the developments in the tactics used to advance its insurgency. In the process, I document how state military and police forces used violence in ways almost as brutal and as wanton as that of Boko Haram.

The state's failures continue to be documented in Chapter 4: "State failure and the geographic, political, socioeconomic, and transnational factors involved in the insurgency." These failures do 
not end with the violence enacted upon its citizens, but include corruption, the political manipulation of religious identities, and a failure to provide educational and health services, along with services that would help assuage the economic despair of many Nigerians, especially in the northern region. This is only part of the answer to the question posed in the title of the chapter, however. In providing a fuller answer, there is an examination of the continuing effects of the colonial policy of indirect rule on the development of and disparities between Nigeria's northern and southern regions. Since independence, not only have those effects been continually reinforced, but there has also become a deepening relationship between religion, politics, and power.

This relationship, combined with the state's failures and its corrupt leaders (seen as "unIslamic" by Boko Haram), creates a vacuum of trustworthy, righteous authority with the best interest of the people in mind. Muhammed Yusuf and, to an extent, Abubakar Shekau were able to take advantage of this vacuum, inserting themselves into the void as authority figures willing to stand up to an un-Islamic state and fight for the best interests of Muslims around the country. The final part of the answer to why Boko Haram has come to exist when and where it does has to expand the discussion into the global arena. There are larger international forces at work that have affected the development of the insurgency and which, on the surface, would appear to have little to do with Boko Haram or northern Nigeria including technological advances and broader economic factors particularly with regard to the oil industry. It is these forces though, these transnational connections economic, political, technological — that make Boko Haram not just a Nigerian problem but a global one, if not necessarily in effect than certainly in causation.

By examining the common framing of Boko Haram and its insurgency, the historicalgeographical foundations of its ideology, the development of the group and its attacks and tactics, and the political, geographical, and socioeconomic factors surrounding the crisis, I show that there is no single factor that explains Boko Haram apart from the others. All of these issues are connected 
and should be analyzed as such. In the concluding section of this project — "The fight for the future" - a number of proposals are outlined which, if implemented, could help secure the future of Nigeria and of the millions of people affected by Boko Haram. It should be noted, however, that this conclusion is written with the full knowledge that it is far easier to outline proposals and steps to take than it is to implement them, and that the ultimate purpose of this project is not to provide solutions but to foster an understanding that goes beyond surface-level claims of extremism and radicalism and that can be used to underpin solutions that may be more effective, more thorough, and more humane. 


\section{Chapter 1 Framing Boko Haram in scholarly literature}

The scholarly literature on Boko Haram is constituted into a number of different focal areas and there are a wide variety of approaches to understanding the group's genealogy, its motivations, ideology, goals, and actions, and the causal factors that precipitated the crisis in Northern Nigeria. Despite this variety, two modes of understanding are most commonly employed. The first focuses on the Islamic fundamentalism and so-called religious extremism of Boko Haram, arguing that the insurgency can be explained through generalized analyses of religious violence and terrorism (Adegbulu 2013; Agbiboa 2014; Agbiboa and Maiangwa 2013; Babalola 2013; Ikerionwu 2014; Onuoha 2012; Sampson 2013;). The second utilizes theories about relative deprivation and frustrationaggression to argue that socioeconomic conditions in the areas in which Boko Haram operates act as the primary motivation for the insurgency (Agbiboa 2013; Onuoha 2012; Adegbulu 2013). Though less common, other studies of the causal factors behind the violent insurgency of Boko Haram focus variously on rational choice theory (Hansen and Musa 2013); on a deep-seated will to power of the leaders of Boko Haram (Umar 2012); on religious tensions in Nigeria as a whole (Agbiboa and Maiangwa 2013); and on the complicity of the state, either through its actions or its ambivalence (Adegbulu 2013; Agbiboa 2014; Babalola 2013).

The field of study seems to lack an overarching and authoritative examination that incorporates all of these modes of understanding, however. Each of these lenses has a measure of validity and helps to explain certain aspects of the historical precedents and current state of the crisis in northern Nigeria, but are incomplete when used individually. This project seeks to fill that gap. The primary scholarly viewpoints — those that emphasize its Islamist extremism and religious violence, and those based on the socioeconomic and psychological theories of relative-deprivation and frus- 
tration-aggression — are examined in this chapter in order to determine the valid and useful aspects of each, as well as the gaps in the level of understanding they provide.

\section{1 - Religious Fundamentalism, Religious Extremism, Religious Violence}

An examination of religious violence - especially when religious violence is seen as a fundamental aspect of an insurgency — must deconstruct ideas of fundamentalism, extremism, and terrorism, each of which is a tacit part of religious violence as the term is commonly used. Fundamentalism, whether Islamic, Christian, or otherwise, is "a religious movement that promotes the literal interpretation of, and strict adherence to religious doctrine, especially as a return to orthodox scriptural prescriptions and doctrinal originality" (Sampson 2013, 115). Within this conception of fundamentalism, Adegbulu (2013) and Onuoha (2012) refer to Boko Haram as a unique sect within Islam, with emphasis placed on the group's stated goal of destroying the Nigerian state and replacing it with a "traditional Islamic state" (Adegbulu 2013, 266). Hansen and Musa (2013, 282) note that Boko Haram is described in language that consistently evokes extreme fundamentalist ideology: it is "traditionalist, exclusivist, millenarian and fanatically theocratic," and "its conception of the future ideal society is a return to an entirely imagined, 7th century (CE) desert, Arab theocracy." Agbiboa $(2014,54)$, among others, focuses heavily on the etymology of the name Boko Haram — a combination of the Hausa word boko, which directly translates to "book" though it more broadly applies to "Western education" and carries attendant undertones of falseness and duplicity, and the Arabic $b a$ ram, meaning "forbidden" — as evidence of their strict orthodoxy and fundamentalist motivations.

Describing Boko Haram as a fundamentalist group is not inherently problematic. Indeed, as described by Umar (2012), its leaders and members do promote and adhere to a strict, doctrinal ideology which will be examined in greater detailed in the following chapters. The problem comes from viewing the fundamentalism of Boko Haram as the primary antecedent to an inevitably violent ex- 
tremism as in Ikerionwu (2014) and Babalola (2013). Sampson (2013, 115) provides a useful definition of religious extremists, arguing that they are in fact religious fundamentalists, but that they "take religious conservatism and intolerance to an unreasonable extent, by manifesting violence against those who hold contrary religious views." In following this logic, one can be a religious fundamentalist without resorting to violence against those with differing or opposing viewpoints, but the religious extremist always takes up arms against anyone who does not share in their ideology. Violence is the primary course of action, the first resort, for the religious extremist — and for Boko Haram in the viewpoint of scholars who confine their focus too strictly to the religious aspect of the insurgency. The violence of an extremist is not a means of protection or defense but of destruction and control, a manifestation of the most profound intolerance.

Though dependent on particular interpretations of religious doctrine and the context of particular situations, religious fundamentalism is not an inevitable precursor to extremism nor does it inherently promote the necessity of violence. Umar (2012) provides the most thorough evidence of this fact, especially as it relates to Boko Haram, in his examination of the debates between the prominent Salafi preacher Ja'far Adam and Muhammad Yusuf, who was once one of Adam's favorite students before splitting off and beginning the formation of Boko Haram. While Yusuf denounced Muslims seeking Western education and working for the government and military, Adam provided "intellectual and moral counter-arguments" in which he viewed the participation of well-educated Muslims in politics and civil service as a necessary part of ensuring the best interests of Muslims throughout Nigeria (ibid, 132-134).

Rather than calling on Muslims to attempt to end their perceived oppression by the government through force, and urging a willingness to die as martyrs in the struggle for an Islamic government, as Yusuf would eventually do before his death, Adam opposed confrontation with state forces. Instead, he advocated "the non-radical path of tactical acceptance of the necessity of working 
with the non-Islamic government in order to achieve incremental improvement pending the establishment of an Islamic government” (Umar 2012, 137-139). According to Mustafa (2014, 11), Adam's beliefs have directed those of "the main Salafist movement, Iqala, [which] explicitly supports the Nigerian constitution, especially Article 25 which forbids the state from adopting a state religion and guarantees the freedom of belief, conscience and worship, individually or collectively." Furthermore, Wakili $(2009,1)$ notes that upon Nigeria's turn toward democracy in 1999, numerous Muslim leaders in the northern states instructed their followers "to vote for the most credible candidates regardless of political affiliation and perhaps even religious disposition. Political and religious affiliations, and even the implementation of Sharia, were secondary, while the emphasis was placed on the candidates' character and personality." It is both acceptable and common for Muslims who adhere to a fundamentalist understanding of their religion to eschew extremism and work with and within the liberal democratic state.

As important as the separation of fundamentalism and extremism is a critical engagement with the concept of jihad, a concept often attached to the fundamentalism/extremism of Boko Haram. Jihad was and is not always or necessarily the violent individual religious duty that is often invoked by militant groups and those seeking to understand them today. Instead, the concept of jihad has evolved over time based on "an elaborate political-theological vocabulary in which jurists, men of religious learning, and modernist reformers debated and polemicized in response to varying circumstances" (Asad 2007, 12). Islamic fundamentalism does not inherently involve a violent form of jihad. To imply that this is the case is as inaccurate as the homogenization of any religion into a monolithic entity and the assumption that any religious sect or group of people who share an ideology always acts in a certain way.

Both Agbiboa (2013) and Forest (2012) provide further evidence of this in describing at least three separate factions that exist under the larger Boko Haram umbrella. One of these remains mod- 
erate and opposed to the violence of the faction which is most often referred to when discussing Boko Haram. The second is welcoming of a cease-fire and amnesty agreement with the government, while the third remains steadfast in its refusal to negotiate or back down. Each of these factions shares an equally fundamentalist understanding of Islam. The disagreement they share over how to interact with the state and its forces demonstrates the misunderstanding at the root of the focus on fundamentalist ideology as a motivating factor in the turn towards violence. Thus, Umar $(2012,136)$ rightly concludes that fundamentalism may lead to violence but not necessarily and certainly not in all cases. The mediating variables preventing or slowing a turn towards violence often include economic opportunity, the ability of the state to provide for its citizens, and the ways the state responds to dissidence. The following chapters will provide greater detail regarding these mediating variables, along with the different factions of Boko Haram, including more recent fracturing that has taken place in the latter half of 2016.

The attachment of ideology to acts of violent extremism is arguably the most critical element of the common understanding of Boko Haram as the perpetrator of violence of a radically different type — and of a far deeper evil — than violence enacted by the state or by other non-religious militants. In placing the causal motivations of Boko Haram within the realm of the ideological, the violence that is perceived as arising from their religious fundamentalism is instead "raised above a simple label to a set of descriptive characteristics and substantive claims which appear to delineate it as a specific 'type' of political violence, fundamentally different to previous or other forms of terrorism" (Agbiboa 2013, 69). The belief that the violence of a militant religious group is somehow worse or more evil than the violence of state forces or non-religious militants is a particularly problematic outgrowth of having too narrow a focus on the ideological aspect of any particular conflict. Furthermore, the state often appears to believe it alone has a right to violence and it is because the state asserts its sovereignty through this right that its challengers are so often violent in response. Rather 
than promoting an understanding of the context within which an insurgency develops, this viewpoint only hardens a belief in fundamentalism as antithetical to modern global society and promotes the idea of a "clash of civilizations" between Islam and the West (Huntington 1993).

The primary goal of religious extremists is, unlike the political or economic motivations of secular militant groups, incompatible with the liberal democratic state within this understanding. Additionally, their end goal is incompatible with modernity as a whole because their motivation lies in the desire to return society to an ancient, idealized past. As an extremist religious group, this approach labels Boko Haram as "absolutist, inflexible, unrealistic, devoid of political pragmatism and hostile to negotiation" (Agbiboa 2013, 70). There is little room for analysis of the myriad geopolitical and socioeconomic conditions that affect any conflict around the world when one views conflicts involving religious extremist groups as conflicts between modernity and an ancient, unchanging past leaves. Regarding northern Nigeria, the crisis gets reduced to a continuation of a monolithic, transhistorical movement.

It is critical to understand historical precedents and the ways in which the region's and country's past have allowed its present to develop as it has. But one cannot simply argue, for example, that Boko Haram's origins in Borno state "should come as no surprise because unlike the other northern Muslim-dominated states, Borno state was once part of the medieval Kanuri Empire of Bornu, and is home to the Kanuri people who prior to the attainment of independence in Nigeria, were known to have led an anti-colonial struggle led by the pan-Kanuri nationalist movement" (Agbiboa and Maiangwa 2013, 387). There are far too many other factors to consider beyond a medieval empire and an anti-colonial struggle to say that location of Boko Haram's origins should come as no surprise simply for those reasons. Boko Haram is, in this view, only the present-day manifestation of the ideologies and grievances of centuries ago. This lens obscures the importance of historical and 
political contexts and movements and, in doing so, erroneously reduces political violence to an outgrowth of culture and religion.

Furthermore, distinguishing between religious and secular violence implies that extremist violence is especially savage because it is religiously motivated, rooted in a sense of divine duty or in response to a theological demand (Agbiboa 2013, 70). Boko Haram is seemingly unconstrained by modern morality, aiming for maximum devastation and continually increasing body counts. Additionally, "in contrast to the supposedly more measured attitudes of secular groups," religious extremist groups are capable of inspiring complete and utter devotion from their members (ibid 71). Adegbulu $(2013,269)$ also operates within this context, arguing that Boko Haram can be understood within "the commonality in all cases among Muslim terrorists [that] is the fatalistic indoctrination which teaches the need to fight and die in the course of defending Islam so as to earn the status of martyrs." Sampson (2013) and Ikerionwu (2014) draw similar parallels between Boko Haram and current and historical conflicts involving Muslims around the world. Religion and religiously motivated anger are thus cited as "the center of most violent conflicts around the world" in the past two decades (Sampson 2013, 104) as "fundamentalist movements arose, committed to the militant purifications of religious doctrines" (Ikerionwu 2014, 45).

This understanding of Boko Haram inevitably renders the group incomprehensible within the worldview of secular modernity. This results in an otherization of Islamic fundamentalists as a whole, the core issue with this mode of understanding. The members of Boko Haram are acting in the name of their religious beliefs, which means they are outside the realm of logical action, impossible to be reasoned with, and directly opposed to anyone who believes in the liberal-democratic state and its ideas of secular modernity. They are not considered members of the state or even of the modern world. They exist entirely outside of modern conceptions of morality and logic, and their 
worldview is antithetical to secular, liberal-democratic values. Their militant operations, cloaked in fundamentalist language, impose archaic, pre-modern animosities onto the modern world.

When defined solely or primarily in terms of religious fundamentalism, religious extremism, and religious violence, the members of Boko Haram are being defined "as morally underdeveloped — and therefore premodern — when compared with peoples whose civilized status is partly indicated by their secular politics and their private religion and whose violence is therefore in principle disciplined, reasonable, and just" (Asad 2007, 45). Ultimately this mode of understanding fails to grasp what Boko Haram's form of militancy really is: an insurgency that, while influenced by its historical context — as well as its geographic, political, and socioeconomic contexts — is as modern in nature as a secular one. As Mamdani $(2005,57)$ argues, “Contemporary 'fundamentalism' is a modern political project, not a traditional cultural leftover." The idea of a clash of civilizations falls apart in light of the fact that there has never been a self-contained civilization that has persisted throughout time with a static system of values untouched by outside influences and free of the pressure of historical context.

\section{2 - The Socioeconomic and Political Motivation of Boko Haram}

Relative deprivation theory and frustration-aggression theory make up the second most common mode of understanding Boko Haram. The scholars who use these theories do so in order to contextualize the group's motivations and actions outside the realm of religious fundamentalism, extremism, and violence. The socioeconomic and political marginalization of the Nigerian people, especially those in the northern region, forms the basis of both of these theories.

Relative deprivation theory, as demonstrated in Adegbulu (2013), Agbiboa (2013), Gurr (1970), and Onuoha (2012), is based on the disparity, whether real or perceived, between the way

people believe things should be and the way things actually are, or between the way people see 
things to be for a competing group and the way they see things as being for themselves. Agbiboa $(2013,75-76)$, for instance, notes that there is "a discrepancy between the 'ought' and the 'is' of collective value satisfaction," or a "difference between expectations and gratifications." As the disparity (or the perception of it) intensifies so does frustration. Thus relative deprivation theory — arguing the existence of a positive correlation between socioeconomic disparity and a tendency for violence — is informed by frustration-aggression theory. Violence is precipitated by specific underlying and unmet frustrations, and the ought-is discrepancy precipitates violent uprising against those responsible for creating and perpetuating that discrepancy. Indeed, there is evidence to support the argument that Boko Haram's violence is partially a manifestation of deep-seated frustration with socioeconomic deprivation and discrepancies and a corrupt and inefficient government.

Corruption and political malfeasance are endemic across the country. But poverty, income inequality, and scores on human development indicators are even worse in the northern regions home to Boko Haram than the already dire circumstances across the rest of Nigeria. The economic reality of the vast majority of Nigerians is profoundly harsh. Unemployment was at an estimated $23.9 \%$ in 2011, up from around $12 \%$ in 2004-2005, and Aigbokan $(2008,14)$ "estimates that an annual average of about 2.8 million graduates enter the labour market, with only about 10 percent of them securing employment." The high unemployment rate, especially among the young, educated population has contributed to a per capita GDP of $\$ 2,102$ in 2012 that has Nigeria ranked 180th in the world (World DataBank 2014). As a result, 61\% of the population was living on less than $\$ 1$ per day in 2010, and the total number of people living in absolute poverty has risen from 68.7 million in 2004 to 112.5 million in 2010 according to the most recent data from the Nigerian National Bureau of Statistics (NBS 2012). In comparison to previous decades, there has been "a quantum leap in the number of the poor from about 19 million in 1970 to a staggering 90 million [out of a total population of 123 million] in 2000" (Agbiboa 2012, 336). 
Nigeria was ranked number 158 on the United Nations’ Human Development Index (HDI) in 2005, worse than every other nation in its entire peer group (Oshikoya 2008, 41). It was ranked number 153 out of 187 countries, with a score of 0.471 , in the latest report from 2013 (UNDP 2013). Its literacy rate is still woefully low at 61\% in 2010 (World DataBank 2013) and its life expectancy at birth, at 52.3 years, is nearly seven years lower than the average of the other Low HDI countries (UNDP 2013). This is no doubt at least partially due to attacks on civilians by Boko Haram and state forces alike, and is likely also in large part due to the fact that government health expenditures have remained at a stagnant level of 6-8\% of total government expenditures since 2004 (World DataBank 2013). Perhaps an even better indicator of the massive inequality in Nigeria is the Inequality-adjusted Human Development Index (IHDI).

Because HDI "masks inequality in the distribution of human development across the population at the country level," the United Nations introduced IHDI in 2010, "which takes into account inequality in all three dimensions of the HDI by 'discounting' each dimension's average value according to its level of inequality" (UNDP 2013). IHDI portrays a much more specific measure of actual development compared to the potential development measured by HDI. Nigeria's overall HDI is 0.471 , but when adjusted for inequality it falls to 0.276 , "a loss of 41.4 percent due to inequality in the distribution of the dimension indices" (ibid). Removing the wealthy elites from the equation leaves Nigeria's human development indicators at 58.6 percent of what they were, evidence that the vast majority of Nigerians are much worse off when income inequality is taken into account.

The comparison of the socioeconomic realities between the northern and southern regions of Nigeria may be even more illuminating, however. In looking at the six geopolitical zones of Nigeria — south-south, south-east, south-west, north-central, north-east, and north-west — there is a stark contrast between the north-east home of Boko Haram, with an HDI of 0.332, and the southsouth, which has the highest HDI of the six regions at 0.537 (UNDP 2013). Table 1 shows the HDI 
levels of each of the six geographical zones, based on the most recent data available.

\section{Table 1: Human Development Index by Geopolitical Zone 2009} (Source: UNDP 2013)

\begin{tabular}{|l|c|c|c|c|c|c|}
\hline Zone & South-South & South-East & South-West & North-Central & North-East & North-West \\
\hline HDI & 0.537 & 0.471 & 0.523 & 0.490 & 0.332 & 0.420 \\
\hline
\end{tabular}

The poorest five states are all in the northern region as well. The north-east and north-west zones had the highest poverty rates in the country in 2010, at 64.8 and 61.2 percent respectively, compared to the south-east zone which had the lowest poverty rate at 31.2 percent (Agbiboa 2013, 76). These statistics are only a small sample of the evidence often cited in studies using relative deprivation and frustration-aggression theories as an explanatory mode of understanding Boko Haram and its turn toward violence.

For the scholars using this lens, the corruption deeply entrenched in Nigeria's political and economic systems is equally as important as the rising levels of poverty and inequality. The statistics demonstrating this endemic corruption are numerous and varied. An estimated $\$ 500$ billion was stolen by Nigerian officials between independence in 1960 and the turn of the century (Agbiboa 2012, 335). An additional $\$ 400$ billion of oil wealth alone was stolen by officials between 2003 and 2013 (Sharma 2013, 212). In 2011, a number of Nigerian companies - many of which were likely only briefcase organizations set up specifically for the misappropriation of funds - were paid hundreds of millions of dollars for fuel that was never delivered (BBC 2012). Financial graft and misappropriation of funds are but two examples of only one form of corruption common among Nigerian officials, but the list goes on.

The effects of corruption on the quality of life for the general population are devastating. Agbiboa (2012, 336) notes that "poverty in Nigeria is often tied to corruption because resources earmarked for social development and job creation programs are often frequently diverted into pri- 
vate bank accounts," a practice that has "turned politics into a lucrative business venture in the society because anything spent to secure a political office is regarded as an investment that matures immediately one assumes office." The reappropriation of funds dedicated to improving Nigeria's performance on social indicators has contributed significantly to the country's low HDI and IHDI scores. And for proponents of the relative deprivation and frustration-aggression theories, it provides ample explanation for Boko Haram's violence.

Relative deprivation and frustration-aggression theories explain Boko Haram’s turn towards violence to an extent, just as does emphasis on religious fundamentalism and extremism. Ultimately however, these studies fail to fully acknowledge the complexity of the crisis and its antecedent conditions. Socioeconomic disparities certainly exist generally between the northern and southern halves of the country, and are subsequently perceived as between Muslims and Christians. Chapter four further examines these disparities and their role in Boko Haram's development. But deep divisions of income inequality persist throughout Nigeria not only between geographical zones but between the political and economic elites and the impoverished majority of the population. Most of the country is not besieged by violent insurgency, however. Boko Haram's activities have been largely concentrated in the north-east and north-central zones. The frustration of the majority of impoverished people in the southern zones — who, in fact, may have more direct experience with inequality as most of Nigeria's wealth is concentrated in the south — cannot be assumed to be so much lower than the frustration of the members of Boko Haram that this would provide a sufficient explanation for the rise of a northern insurgency with no true southern equivalent.

Militant insurgency did wreak havoc across the Niger Delta in the southeastern region. But those groups never achieved the success, notoriety, geographical range, or longevity of Boko Haram, nor did the Nigerian government fail quite so utterly in resolving the crisis (Aghedo and Osumah 2014; Hill 2012). And even so, the crisis in northern Nigeria is not one where members of the gen- 
eral population are taking up arms against a corrupt and oppressive government. The insurgency in the Niger Delta was a response to government corruption with regard to the area's oil wealth, and the militants chose their targets more specifically as a result. Boko Haram of late has no apparent scruples about targeting anyone and everyone, military or civilian, Christian or Muslim. Even as they provide a partial understanding of why Boko Haram took up arms in the first place, relative deprivation and frustration-aggression theories, based on the socioeconomic realities of a given situation, have no answer as to why Boko Haram has carried out its insurgency in such a wanton manner. Being based almost entirely on the socioeconomic realities of a given situation, these theories do little to explain why violence erupts in certain areas and among certain groups of people and not others. Likewise, they fail to explain how an insurgency begun in frustration over socioeconomic frustration could turn to a full-on assault with no specific human or governmental targets in mind. Their explanation for the crisis ends up only as partial as that given by studies focusing primarily on religious fundamentalism and extremism.

While the statistical data does indeed show that there is a disparity between both the elites and the majority of the population as well as along geographical lines, this is not a fully formed analysis of the crisis. Instead, Boko Haram is removed from its unique historical and cultural context by invoking this broad psychological construct that aggression is preempted and precipitated by frustration caused by real or imagined disparities. The motivational and causal factors of Boko Haram's insurgency are subsequently aligned with those of current and historical militant groups around the world. That not all impoverished and marginalized people, neither in Nigeria nor in the rest of the world, resort to wanton violence is ignored in the same way that focusing on religious extremism ignores the fact that not all Muslims, not all Nigerian Muslims, nor even all members of Boko Haram are led by their religious fundamentalism to violence. 


\section{3 - Conclusion}

The common approaches to understanding Boko Haram and the lenses through which the crisis in northern Nigeria is viewed, rather than being incorrect, are simply incomplete as they are generally used. When scholars focus on Boko Haram's fundamentalist ideology, the zealotry and religious extremism of its leaders and members, it is often to situate the insurgency within the broader global context of conflicts involving Islamic groups around the world. Because of the nature of these conflicts - the fact that violent Islamic groups (or branches or members of a broader Islamic group) exist in Africa and Asia, Europe, the Middle East, and the United States; the perception of these conflicts perpetuated by Western governments and the media which sketch them in broad strokes of an overarching Islam intent on bringing down Western civilization — focusing too narrowly on religious fundamentalism and extremism means losing sight of the specific contexts within which each group or individual operates.

The context of Boko Haram is not the context of al-Qaeda-linked militants in the Philippines is not the context of the operatives of the Islamic State carrying out attacks in France and Belgium and Germany. Decontextualizing an individual conflict renders it all but intractable, leaving little information on which to base any strategy beyond outright warfare that might bring an end to an insurgency. And in effect, it renders all Muslims, in the eyes of many in the West, as the other, outside of "our" conceptions of civilization and modernity and decency. It perpetuates an attitude of "us versus them," and absolves Western powers — both current and colonial — and liberal democratic governments around the world of any responsibility in instigating, perpetuating, or exacerbating these conflicts.

The use of relative deprivation and frustration-aggression theories to explain these conflicts is admirable in that scholars arguably use these theories precisely because of the flaws inherent in the focus on religious fundamentalism and extremism. There is indeed a measure of relative deprivation 
at work in northern Nigeria that has played a significant role in the development of Boko Haram, as will be addressed in more detail in the following chapters. And certainly it is true that in many cases relative deprivation leads to a frustration that is acted upon aggressively and violently. There have been conflicts throughout history that can be largely and appropriately explained using these theories. But many scholars who use these theories to explain Boko Haram's violent insurgency do so to the detriment of an understanding of the undeniable religious factors and motivations at work, in regards to both the nature of religion in Nigeria as a whole and the specific religious ideology and worldview of the leaders and members of Boko Haram. The relative deprivation of people in northern Nigeria is inherently linked to the history of religion in the region and across the country. The development of Boko Haram's religious ideology is likewise inextricably connected to the socioeconomic deprivation, relative or otherwise, that many Nigerians have faced for decades.

The relative deprivation/frustration-aggression and the religious extremism modes of understanding both attempt to situate Boko Haram within something transhistorical or transcultural, whether religious or ideological or psychological, that can be applied to myriad complex situations sharing a similar basic structure. There are many militant groups around the world who identify themselves primarily in religious terms, thus their conflicts can be explained as extensions of religious fundamentalism and extremism. Most violent conflicts today take place in areas of socioeconomic deprivation and inequality, thus the aggression of these actors can be explained as an extension of their frustration at the situation and relative place in the world. The problem is not that these commons modes of understanding are completely lacking in validity or that the motivational factors they identify for many of the world's violent insurgencies have no place in the discussion. This is true in general, and it is true for Boko Haram specifically. It is impossible to understand Boko Haram without examining their religion and ideology just as it is impossible to do so without studying the socioeconomic inequality that exists in Nigeria. 
The problem, then, is that nothing is transhistorical or transcultural. Nothing exists in the same way across time and space, as a fixed set of values that maintain doctrinal orthodoxy or a static set of psychological adaptations that translate frustration into aggression. Context is everything and the tendency to privilege one of these theories over the other, or to use one at the expense of the other entirely, leaves much of the scholarly work on Boko Haram and its insurgency incomplete. The result is that much that constitutes the field of study is based on one circumscribed viewpoint or the other, each with a limited scope that prevents the inclusion of complexity and nuance that is critical to a deeper understanding of the crisis in northern Nigeria. This project uses aspects of both of these modes of understanding in seeking to provide a more nuanced examination of Boko Haram and, it must be noted, has a significant debt of gratitude to many of the scholars listed above and cited below, regardless of which approach they have taken in their study of the situation. 


\section{Chapter 2 The foundations of an ideology}

There is a complex and interrelated web of reasons why Boko Haram came into existence in northern Nigeria. A full understanding of the insurgency must necessarily touch on each node of that web, each point at which any number of strands come together and intertwine and spread back outwards in connection to other points. In doing so, it may be most productive to begin by looking at the foundational aspects of the thing that the leaders and members of Boko Haram seem to hold in the highest esteem, that which they appear to hold onto as the core of their sense of self: their religious ideology. An examination of Boko Haram must include a discussion of its particular form of Islamic fundamentalism even as it must also avoid making that the primary lens through which it is viewed. Divided up into six sections, this chapter develops an understanding of the ideology and the particular form of Islam unique to Boko Haram.

The first section begins with the introduction of Islam into the area that would become the northern region of Nigeria, as Islamic scholars, traveling along trade routes with merchant caravans, brought the religion to the area's original inhabitants. Subsequently, this section looks at what is variously known as the Fulani War, the Fulani Jihad, or the Jihad of Usman Dan Fodio, a foundational event in the history of Islam in Nigeria that resulted in the establishment of one of the preeminent empires of nineteenth century Africa in the Sokoto Caliphate. In the second section is an overview of the importance of religion in Nigeria, including the introduction of Christianity into the southern region of the Nigerian colony and the relatively rapid spread of both Islam and Christianity among the people of both pre- and post-colonial Nigeria.

Around this time, religious identity began to take precedence over tribal or ethnic identity as much of the population began to place more weight on their identification as Muslim or Christian than as Hausa, Fulani, Igbo, or any of the other tribes and ethnic groups that were cobbled together 
into a single colonial entity, a trend appears to have continued to the present day. Differences in the nature of religion between the northern and southern halves of the country will also be analyzed. In this vein, section five looks at historical patterns and expressions of dissent and tolerance among Muslims in northern Nigeria, including a comparison to those of both Muslims and Christians in the south. Finally, this overview connects to the present day through a discussion of the ways in which the history of religion in Nigeria as a whole and of Islam in the north in particular, along with the methods of expressing dissent among northern Muslims, established a precedent for Boko Haram and paved the way for the development of its ideology.

\section{1 - The introduction of Islam into what is now northern Nigeria and the foundation of the Sokoto Caliphate}

Boko Haram has increased its power and capacity and expanded its reach primarily in the years since Muhammad Yusuf's extrajudicial death at the hands of police forces in 2009, but some of its roots can be traced back even beyond the 20th century and the establishment of the Nigerian colony. The first contact between Islam and the original inhabitants of what would become the northern states of present-day Nigeria took place in the 11th century. As trade routes extended outward from the Middle East and North Africa, merchants involved in the trans-Saharan gold trade began moving through the region. The Islamic scholars traveling with these caravans introduced the religion to the regional tribes and the kingdoms and city-states of the Hausa for the first time (Lubeck, Lipschutz, and Weeks 2003, 14). Islam gradually solidified its position in the region over the next few hundred years.

As local rulers began to convert to Islam, "Muslim scholars institutionalized Muslim law, literature and Muslim institutions as part of a strategy to construct a centralized, urban, bureaucratic state apparatus over the lineage-based societies in the countryside" (ibid). The transition to Islamic structures of governance was neither smooth nor linear, however. While a number of manuscripts 
recorded by Muslim authors at the time describe "periods of Muslim reform followed by periods of regression to traditional and syncretic practices," eventually the "discursive power of Islam and the institutions of a Muslim mercantile economy gradually became embedded in the cultural practices of the diverse societies" living in what would become the northeastern Nigerian states (ibid, 14-15).

The most important period of Islamic development in the region began in the late 1700s. Lubeck, Lipschutz, and Weeks (2003, 14-15) provide an excellent description of the changes underway at this time period. This began with the increasing influence of Usman Dan Fodio, "a charismatic Muslim scholar influenced by the Islamic revival centered in Mecca and Medina" who preached "against the 'backsliding' rulers of the Hausa-speaking city states accusing them of injustices, corruption, illegal taxation, tolerating un-Islamic practices and repression of ... 'Sharia-minded' Muslims." Beginning with the Jihad of Usman Dan Fodio, which took place from 1804 to 1808, and stretching across the following half-century, Fodio, along with his brother Abdullah and his son Mohammed Bello, "constructed a geographically vast and multi-ethnic Muslim empire — the Sokoto Caliphate - extending across northern Nigeria, Niger, and Cameroon and even into the Yorubaspeaking regions of Illorin.” Through its military strength and the centralized authority of its Islamic institutions, the caliphate became "one of the largest and most complex pre-colonial African states, one that was recognized in the wider Muslim world."

The authority and influence of the caliphate ushered in a period of a sort of Pax Sokoto that allowed Islamic scholars to extend their intellectual reach along expanded trade routes, a combination of networks referred to as the ulama. As a result, "Islamic law provided the cultural cohesion that enabled the rulers and ulama to administer one of Africa's most extensive and complexly organized agrarian bureaucratic empires," one that consisted of an "urban, highly commercialized, people by free and slave-origin peasantry and administered by literate bureaucrats" and that "unified 
tens of Muslim emirates under Sharia, a population numbering a million or more people from Niger to Cameroon."

Despite some sectarian divisions and attempts by some of the emirates to rebel, the Sokoto Caliphate retained its territorial, economic, and cultural authority until the British conquered it in 1903. Much of the structure of Islamic authority was allowed to remain intact even after the colonial conquest, however. Facing pressure from the British government at home to keep costs down, the colonial administration was left without sufficient personnel to effectively govern the vast territory and large population they had cobbled together as the Nigerian colony. As a result, they instituted a policy of indirect rule, governing through preexisting local institutions as much as possible, particularly in the northern half of the colony (Campbell 2013, 1-3; Aghedo and Osumah 2014, 2).

The traditional centralized authority that had been the strength of the former Sokoto Caliphate provided the foundation for the indirect rule of the northern half of the colony. The British allowed Muslim leaders to keep their traditional institutions of power in exchange for implementing certain policies and keeping the peace (Campbell 2013, 2-4; Rufai 2011, 170). This agreement, a sort of indirect rule by way of power-sharing between the British authorities and the Muslim elites, meant that "slave raiding and trading were abolished but not slavery; higher taxes, forced labor and other forms of domination by the ruling class over the commoners were buttressed by the technical power of the British empire; Muslim district heads were placed over non-Muslim subjects and Christian missionaries banned from proselytizing in Muslim areas; traditional checks on autocratic power were eroded; and most importantly, Islamic law was institutionalized and rationalized throughout the Protectorate of Northern Nigeria" (Lubeck, Lipschutz, and Weeks 2003, 15).

In practice, this institutionalization and rationalization of Islamic law meant that punishments such as stoning and amputation were banned, but the "Sharia-based civil and criminal code and a court system under the authoritarian rule of emirs and their clients" was allowed to remain 
(Lubeck, Lipschutz, and Weeks 2003, 15). In addition to allowing the institutionalization of Islamic law, the colonial administration began to intentionally entrench a religious divide between the northern and southern halves of the colony by nurturing among northern Muslim leaders a "fear that Christianity would provide Western education to the people of the North which was capable of stimulating their political consciousness against the traditional institutions" (Onapajo 2012, 46). Unable to predict the repercussions, the colonists had begun the creation of a space in northern Nigeria in which the leaders of Boko Haram could logically develop their own opposition to Western education nearly a century later. In short, reverberations from the British method of ruling the Nigerian colony are still being felt today and have directly contributed to Boko Haram's establishment in the north. The institutionalization of Islamic law and the colonialists' indirect rule through Islamic institutions may be some of the earliest indicators that religion would come to take a profoundly important place in the lives of the Nigerian people and within the state as a whole.

\section{2 - The importance of religion in Nigeria and the spread of Christianity and Islam throughout the population}

Estimates for 2014 put the Nigerian population at roughly 177 million, and many of those people "note proudly that they live in the "world's most religious country" (Campbell 2013, 43). Religion seems to seep into nearly all aspects of life throughout the country. Prayer is routinely used to open and close public events. Divine intervention is often praised or blamed for things that happen in the public sector and in individual lives. And many Muslims and Christians alike reject the idea of a separation between church and state (ibid, 45). Nigeria is also home to both the largest Muslim population in Africa as well as the largest Roman Catholic seminary in the world, a juxtaposition that provides evidence of the country's stark religious divide (Rufai 2011, 168; Campbell 2013, 51).

Between 46 and 52 percent of Nigerians identify as Muslim, and between 40 and 46 percent identify as Christian (Campbell 2013, 52; CIA 2017). The two major religions have expanded signifi- 
cantly over the last century. In 1900, 26 percent of the population identified as Muslim while just one percent identified as Christian. By 1963, these numbers had risen to 47 percent Muslim and 35 percent Christian (Campbell 2013, 53; Ibrahim 1991, 116). From there the rapid spread of Christianity continued, leading some to believe that Christians have in fact become the majority, a possibility which, "for Muslims, who long regarded West Africa as their own neighborhood ... is disquieting," at least according to Campbell $(2013,53)$.

These numbers raise the question of why these two religions, and Christianity in particular, were able to spread so rapidly and so thoroughly subsume previously existing local religions. A compelling response can be made by drawing from Smith (1978) and Douglas (2002), each of whom has argued that both religion and culture are means by which an individual comes to find or understand his or her place in the world. Navigating the world requires the use of cognitive maps, systems of order which help locate oneself in relation to other people, events, ideas, practices, and so on, and which, ultimately, give one a sense of meaning. Religion is one such map, one way through which to navigate the world. As such, it is "the quest, within the bounds of the human, historical condition, for the power to manipulate and negotiate one's 'situation' so as to have 'space' in which to meaningfully dwell” (Smith 1978, 291).

Cognitive maps — religion in this case — provide a way to deal with ambiguity and anomalous events in order to solidify one's position in the world. Rather than being mentally and psychologically overwhelmed by "a chaos of shifting impressions, each of us constructs a stable world in which objects have recognizable shapes, are located in depth, and have permanence" (Douglas 2002, 45). Religion is a means of understanding the world, of negotiating between a confluence of experiences and events, in order to find meaning, stability, and place. Boko Haram's members and recruits — young people who often find themselves unmoored, separated from their families, their lives un- 
structured by either employment or formal education — need the guidance of cognitive maps as much as anyone, which is likely a large part of the group's appeal.

In this light, the relatively rapid spread of Islam and Christianity makes sense. The 20 th century was a time of profound change for Nigeria and for Nigerians. As the country transitioned from colonization to independence, and then from military to democratic rule, the people were presented not only with new political systems and institutions, but with new forms of religion, education, technology, and so on. With these changes, it became necessary to reshape cognitive maps in order to navigate through and find stability within what must have seemed, in Douglas's words, a chaos of shifting impressions. Adapting to the religion of those in authority would have been a logical way of doing so, especially in the face of aggressive proselytization.

In this way, conversion to Islam or Christianity was for many Nigerians "a tactical move to reappropriate and domesticate a new spirit, [and] was also a ruse to wiggle through the new configuration of political forces” (Ibrahim 1991, 119). This was religion as an instrument of political negotiation and accommodation. Many new converts still maintained important aspects of their own religious systems even after taking on the mantle of one of these new religions. As a result, most Nigerians in the early 1900s found nothing problematic in moving from one deity or ideology or ritual to another and back again even as they continued to identify as Muslim or Christian (ibid, 117). By the turn of the century however, religious identity had surpassed ethnic identity in importance in many areas (Rufai 2011, 169).

As Islam and Christianity spread across the country and over the course of the century, what initially seemed, or for many in fact was, only a nominal form of conversion transitioned to a deeply important religious identity. Just as many individuals found conversion to be a tactical, stabilizing move, the government found that its citizens' adherence to one of two major religions was useful for its purposes as well and the state began to use religion as a political tool. 


\section{3 - The deepening attachment to religious identity over tribal or ethnic identity}

Nigeria's colonial and independent political leaders alike have consistently encouraged and manipulated its population into identifying as either Muslim or Christian. This began as the colonial administration sought to delegitimize local religions already in place. Local religions were reduced to paganism and, it has been argued, "systematically exterminated in the religio-cultural life of the Nigerian peoples" in what the colonial administration referred to as its "civilizing mission" (Onapajo 2012, 44). At the same time, colonial authorities castigated "all 'sects' [within Islam and Christianity] that exhibited any signs of non-orthodoxy, usually defined as resistance to existing political authority" (Ibrahim 1991, 116). Since Nigeria gained its independence in 1960, the state has continued ac-

tively working to create and entrench two specific, circumscribed and normative religious identities among the Nigerian people, to homogenize them into a strict dichotomy of Islam and Christianity. Ostensibly, this was and continues to be an attempt if not to fully unify the country than to align the population into two camps at least, instead of dozens or more. In reality it is simply a means of domination (Ibrahim 1991, 117).

The creation of these identities by the state is an especially effective form of power because it is cloaked in the sense of personal agency involved in the use of cognitive maps to understand one's place in the world. In this way, "the subject is constituted through an exclusion and differentiation, perhaps a repression, that is subsequently concealed, covered over, by the effect of autonomy" (Butler 1992, 12). The personal agency and autonomy enacted through conversion to Islam or Christianity in order to reconstitute cognitive maps or reappropriate new forms of belief is, in reality, one of the methods through which the state can repress and control both individual persons and the circumscribed identity groups to which they belong. It is in this way that "in the very struggle toward enfranchisement and democratization, we might adopt the very models of domination by which we were oppressed" (ibid, 14). 
The agency through which individuals apparently come to embody these identities may appear to be a form of individual power or a means by which one can limit repression by the state or escape it entirely. As will be further explored in later sections, Islam in particular has become "an alternative to the perceived failure of secular ideologies" perpetuated by the state (Rufai 2011, 168). But this agency may only be on the surface. The belief that these identities are an effective form of opposition to the state may only be solidifying state power. By engendering this sense of normativity cloaked in individual agency, the state is acting "precisely to safeguard and reproduce a position of hegemonic power" (Butler 1992, 8).

Thus the Nigerian state has worked to create and solidify identities among its population in an attempt to repress and control them, to make them malleable and willing subjects who conform nicely to specific identities. Certainly it cannot be said that it has succeeded in every case. But there is no denying the importance of these identities, of perceiving oneself as Muslim or Christian first rather than Nigerian, in some cases rather than Igbo or Yoruba or any one of the 250 ethnic groups within the country (Aghedo and Osumah 2014, 2), although it should be noted that the primary selfidentifier one uses is often dependent on the context of the situation and the importance of ethnic, tribal, or religious identity can fluctuate accordingly. And subsequently there is no denying the usefulness of these identities to those who would manipulate them and use them as a means through which to gain and retain power.

At the same time that the state worked to authorize its power by creating subjects of domination through the construction of normative identities, it did so also through the construction of particular conceptions of religion useful for advancing its agenda and upon which those identities would be based. For Boko Haram, religious identity is particularly important and the idea of an Islamic community - and the threat of those who have betrayed that community through religious innovations, or bid'a - is a major motivator behind the insurgency. 
It is helpful here to return briefly to the argument that religion is not a naturally occurring thing that exists in the world (Smith 1978). Because religion is not a naturally occurring thing, it changes in form and content and impact across cultures, time, and space. In this same way, there is likewise no transhistorical and transcultural thing as secularism (Cavanaugh 2009, 9). Instead, "religion is not simply found, but invented ... [It] is not simply an objective descriptor of certain kinds of practices that show up in every time and place. It is a term that constructs and is constructed by different kinds of political configurations" — and the same is true of secularism (ibid, 58).

Rather than simply existing throughout time as the separation church and state, secularism is, in reality, "the rearticulation of religion in a manner that is commensurate with modern sensibilities and modes of governance" (Mahmood 2009, 65). Because religion is a force that has the power to legitimize or delegitimize political regimes, the secular state would logically attempt to rearticulate it to serve its own needs. It would work to instill a certain conception of religion(s) or religious identity within its citizens that would suit its particular needs or desires (Onapajo 2012, 45). And thus not only would the Nigerian state seek to authorize its power by getting its citizens to identify themselves as Muslim or Christian, but it would actively be creating the very conceptions of Islam and Christianity to which they would adhere.

The crux of this argument is that the state invents and manipulates constructs of religion that serve its agenda, authorize certain forms of power, and justify both domestic and, especially, foreign policies (Cavanaugh 2009). In this the state also finds justification for its marginalization of and violence - both physical and non-physical — towards adherents of other religions. This is especially true when those other religions are comprised of dogmas and ideologies perceived, at least within the state's invented construct of religion, as primitive or backward or inherently violent. The invention and manipulation of self-serving constructs of religion is especially true in looking at instances of colonization or Western domination over non-Western peoples. In fact, the political ma- 
nipulation of religion "is little different from previous forms of Western imperialism that claimed the inferiority of non-Western others and subjected them to Western power in hopes of making them more like us" (Cavanaugh 2009, 14). The colonial regime began the political manipulation and Westernization of religion in Nigeria. Since independence the Nigerian government, seeking to establish itself within the global economy as a secular liberal-democratic state, has continued to perpetuate the relationship between religion, politics, and power.

\section{4 - Differences in the nature of religion and tolerance between the northern and southern regions}

As the colonial and independent authorities worked to entrench two circumscribed religious identities within the Nigerian people, certain distinct geographic and ethnic divisions also began developing between the northern and southern regions of Nigeria. Certain elements of the approach to religion still vary along geographic and ethnic lines despite the state's effots to corral Nigerians into its own conceptions of Christianity and Islam and the increasing importance of religious identity. These dividing lines also seem to affect the ways in which the people of the northern and southern regions approach religious tolerance and conversion.

For many of the ethnic groups in the southern region and particularly for the Yoruba, there remain the relatively cavalier attitudes towards religious conversion that were a distinct characteristic of the initial spread of Islam and Christianity throughout Nigeria. Today, just as it was during the first half of the twentieth century, converting "from one religion to another (and back again) is done with ease, and is relatively common" such that "religious membership is a matter of strictly personal choice, and conversion can be a career move" (Last 2012, 23-24). It is not uncommon for individuals in the southern region, especially in urban areas, to convert from Islam to Christianity or vice versa for any number of reasons: as a "career move," but also for marriage, family reasons, or a simple change in personal beliefs. 
Because of this (along with the fact that the Yoruba nation has a political and economic agenda that is independent of religion), a group like Boko Haram that preaches intolerance and views conversion from Islam to Christianity as a form of treason would be unable to gain traction and amass a following in Yorubaland — or, it would seem, anywhere else in the southern region — as it has in the north. Furthermore, as will be explored in greater depth in the following section, Islam places a far greater emphasis on the importance of the religious community, the umma, than does Christianity. For Muslims in the southern region, having routine daily interactions with Christians and with those who have converted from Islam to Christianity or the reverse, the religious community likely loses at least some of its importance, and the strict adherence and subjugation to, and possibly violent enforcement of, an orthodox ideology likely becomes less attractive.

Likely the only way a group like Boko Haram could even exist in the south would be if it took the form of a sort of underground, secret society — which is, in fact, what some Yoruba perceive Boko Haram to be (Last 2012, 24). It would be all but impossible for such a secret society to exist in Hausa society on the other hand, especially in a crowded city ward in Maiduguri, because of the lack of tolerance for dissent; thus the aforementioned tendency to push the dissenters into the rural areas. If Boko Haram or a similar group tried to plant its roots in the southern region, it would have been entirely more difficult to gain the amount of support and recruit the number members that it did in and around Maiduguri. The regularity with which Muslims and Christians in Yorubaland interact with each other, as neighbors or family members or even husband and wife, would likely prevent such levels of support, as would the regularity with which people convert (and are often publicly known to have converted) in one direction or the other usually with little judgment or loss of social standing.

The differing levels of tolerance that align significantly with the geographic division between peoples of the northern and southern regions also manifests itself in a divide between northern and 
southern Muslims. The levels of support for a push to implement Sharia law that took place in the early 2000s provide evidence of this: 66 percent of northern Muslims supported the movement to codify the tenets of Sharia law in the public domain as compared to only 38 percent of Muslims in the southern regions. Southern Muslims were far less likely to want (or to admit to wanting) the codes of conduct and behavior prescribed by their religion to be demanded of non-Muslims because of attitudes toward conversion, because of their regular and routine interactions with Christians as friends, family members, and neighbors. Once again, this demonstrates a common attitude of tolerance that would have made it far more difficult for Boko Haram to establish itself in the south. In the north, historically speaking, rather than a pattern or common attitude of tolerance, there is a lengthy history of dissent enacted by northern Muslims since the late nineteenth century.

\section{5 - Political Islam and the historical patterns of dissent and discourse among Muslims in northern Nigeria}

It is important to understand historical patterns and expressions of dissent among Muslims in northern Nigeria in order to understand how and which of these are reflected in the dissent of Boko Haram. Additionally, this understanding helps explain how historical patterns and expressions of dissent helped paved the way for Boko Haram's foundation by establishing a culture where dissent is permissible, if not outright tolerated or encouraged, even if at times the expression of that dissent may turn violent.

Some of the first historical parallels seen between the expressions of dissent by northern Muslims and those of Boko Haram can be found in returning again to the Jihad of Usman Dan Fodio in the early nineteenth century. With the events that led to the establishment of the Sokoto Caliphate, there was initiated a "pattern that is common to movements of dissent in Muslim northern Nigeria," according to Last $(2013,7)$. This follows four main stages, the whole of which has re-

peated itself numerous times over the last two centuries. "Stage 1 sees an Islamic scholar 'on the 
make' attracting a small following; the local ruler supports him in order to win his political backing. Some sons of the local elite join and protect the nascent community. In stage 2 the scholar's following grows so large that the local ruler and his officials get seriously alarmed and try to limit the scholar's following. Stage 3 sees subordinates from the ruler's polity get involved in a major violent fracas with subordinates from the scholar's community; the confrontation (often involving the release of prisoners) is too big to be ignored. In stage 4 all-out war is formally declared between the local ruler's state and the scholar's community, resulting in (usually) the scholar losing out, but on at least one famous occasion the scholar's community eventually won after a four-year 'jihad' and set up a new state (the Sokoto Caliphate). The leader then, Shaikh [Usman Dan Fodio], was of course a scholar of far greater calibre than any of today's 'dissidents' such as Mohammed Yusuf of Boko Haram, but the government's response was strikingly similar." As it was with Usman Dan Fodio and his followers, so it was with the Maitatsine, with the Yusufiyyah — as the followers of Mohammed Yusuf were initially commonly known — and Boko Haram.

Unlike the communities of lesser known scholars whose influence ended in the fourth stage of this pattern, however, in these later instances "the dissidence did not die with its leader: the 'violence' over the years that followed got much worse, occurring in quite distant towns- the dissenters were dispersed, not destroyed. The government's use of overwhelming force seemed to legitimate counter-force, converting a relatively non-violent but open dissent into a covert dissidence that used violence to make its new, vengeful anger clear" (Last 2012, 7). This is precisely the trajectory of Boko Haram. Muhammed Yusuf was killed in police custody and his followers - the dissidents, in this case - dispersed, but when they reemerged later it was as a far more threatening presence, establishing their own system of violence to emphasize their anger.

In later years, even as the northern elites began working the colonial authorities and within the structures of indirect British rule, many common northern Muslims embraced colonial rule with 
much less enthusiasm. But while the colonial authorities were able to prevent major displays of overt dissidence through the establishment and formalization of police forces, courts, and prisons, the conquest of the caliphate by the British remained "reason enough for Muslims to seek opportunities to resist alien non-Muslim rule or at least to express their distancing from any association with that rule" (Last 2012, 17). For some, this distancing meant an increased piety associated with tariqa membership and adherence to Sufi doctrine, in part through the standardization of Qur'anic education. Others came together in millenarian groups that occasionally tried to oust the British Christians and the Muslim elites who worked with them outright. Although 'overt armed 'rebellion' among Muslims was rare," there were a number of relatively minor uprisings in the early 20th century that were violently put down by colonial forces (ibid 22). By the 1930s however, most of these "radically Islamic groups" had distanced themselves from mainstream society, migrating to the outer rural edges of the Sokoto region.

The primary pattern of the expression of dissent over the last two centuries, then, is related to this form of outright dissidence transformed into a more covert form of expression. Northern Muslim dissidents have continually used the sparsely populated rural areas to distance themselves physically from the oversight and oppression, real or perceived, of the Islamic authorities and the colonial government alike. According to Last (2013, 30), "the most decisive act of Muslim dissidence was (and still is) to remove your discrete community beyond the immediate surveillance of the authorities in the city — out to a site where you could not be known.” Even after there were major movements of farmers and their families from more densely populated areas into deeper rural areas in the 1920s, the rural areas still "remained suitable for 'radical' dissent communities too." As a result, "radical Muslim communities therefore chose these sites to escape centralized control (in a Nigerian version of bilad al-siba) and live out the Islamically 'pure' lives that they preached." 
This desire or need to move beyond the boundaries of control of the mainstream Islamic and colonial authorities grew at least in part from to the fact that, particularly in northern cities, dissenters could not count on tolerance "whether covert or overt" from those against whom they were dissenting and, as a result, "the best policy, then, was to get the dissenters out of town into the deep countryside where tolerance was practical and possible" (ibid, 23-24). In other words, the movement of dissenters into the deep rural areas initially played out as something of a joint decision between those radical communities and the authorities.

The dissenting groups could practice as they chose away from the intolerance of the mainstream sections of society, and the authorities could rid the urban areas of pockets of dissent and prevent those attitudes from spreading to greater proportions of society. There may, however, have been unintended consequences to the movement of dissent, especially the movement of so-called radical Muslim communities, from urban to rural areas. As the dissenting communities established themselves in the deep rural areas, their presence and the tolerance (or solitude) with which they were met may have worked to normalize more rigidly pious and orthodox forms of Islam in the countryside. As a result, it is possible that many of the boys and young men recruited into Boko Haram in recent years - the majority of whom come from these rural northern areas into Maiduguri - may have grown up in contact with the idea of an "Islamically "pure" approach to life preached by the dissenting communities and their descendants.

When the boys and young men moved from rural areas to urban centers, Maiduguri in particular, the ideology of the leaders of Boko Haram would not have seemed abnormally strict or overly pious. Along with the poverty and lack of economic opportunity they would face in the city as well as the rural areas, the unstructured nature of their lives and the lack of education often needed to help think critically about an ideology, the familiarity with these sorts of fundamentalist ideologies 
would helping to facilitate the transition of boys and young men from almajiri to recruits, members, and foot soldiers of Boko Haram.

In addition to the somewhat self-imposed exclusion of religious dissidents, the historical expression of dissent among northern Muslims — as with practically any form of dissent against a centralized authority, whether that authority is religious or governmental in nature - has taken on a political tone as much as a religious one. The political veneer that makes up a significant part of the dissidence of Islamic groups in northern Nigeria again has historical precedent in early 1800 s. Those years were characterized by "a period of aggressive expansion and 'civil war' in Kebbi, Katsina, Kano, Zaria when a kind of 'franchise jihad' (1806-9) was instituted” by the Shehu, Usman Dan Fodio, and the Sokoto Caliphate (Last 2012, 11). This "franchise jihad" involved recruiting mujahidin forces from across the region and was a critical part of the development of the political nature of Islamic dissent. As a result, "their status (for others) as Muslim reformers [was] replaced by an ethnic identity" (ibid 12), marking the beginning of the transformation of the nature of the dissent that had sparked the conflicts in the first place from religious to political.

Years later, after Nigeria gained its independence and began developing its oil industry, the boom-and-bust cycles of the global oil economies sowed uncertainty into the centerpiece of the $\mathrm{Ni}$ gerian economy, further laying the groundwork for Boko Haram. Meanwhile a series of attempted and successful coups and crises shook the military and democratic governments. A number "Islamists took advantage of the political opportunities offered" by these crises and uncertainties in order to assert their own influence and agendas throughout the north (Lubeck 1999, 14). While the recruitment of mujahidin forces from across the region can be seen as the beginning of the transformation into a political form of dissent, certain strains of Islam — and Islamism in particular, briefly defined as a form of fundamentalism focusing on "religionized politics" (Tibi 2012, 22) — already 
had within them a political focus that has a central role in the expression of dissent and in the development of the ideology of the leaders and members of Boko Haram.

In developing an understanding of the ideology of Boko Haram, it is most useful to define ideology itself as "a set of ideas by which men explain and justify the ends and means of organized social action, with the aim of preserving or reconstructing a given reality" (Barkindo 2013, 31). In relation to insurgency, "ideologies are powerful tools for the mobilization of the masses as well as sources of legitimacy_-sources of the sense of mission of a leader or a ruling group" (ibid). The ideology preached by Yusuf and Shekau provided the framework for the establishment of Boko Haram and helped solidify their places as leaders — for Yusuf, as a leader within the Islamic community of Maiduguri, and for Shekau, as the leader of Boko Haram after Yusuf's death — largely because it was derived from Islamism and its focus on the political aspects of Islam, a perfect antidote to a failed secular state.

The development of Mohammed Yusuf's ideology, the founding ideology of Boko Haram, would be best understood within the historical context of Islam in northern Nigeria, and in particular within the context of Islamism's political focus. Indeed, it could be argued that the main ideological tenet motivating the insurgency is centered around the Islamic conception of political authority. In this vein, Yusuf preached against "socialism, capitalism, military dictatorship, western education and modern statecraft," arguing that the failures of these systems arise from the exclusion of God and that "the solution therefore was to return to the noble, honorable, moral and perfect principles of the rule of Islamic religion, which is infinitely more accomplished, more pure, more glorious, and more complete than all that have been discovered earlier by political and social theorists" (Barkindo 2013, 37). Muslims in northern Nigeria would be able to achieve social justice and economic growth only by reforming Islam and establishing Islamic law as the guiding code of conduct. 
In line with this, the end goal of Boko Haram's insurgency today is "not only to fight a modern state but to ensure that Islamic law is the basis of political organization and civil life in Nigeria, especially Northern Nigeria" (Barkindo 2013, 40). Mohammed Yusuf and his followers started out with a non-violent approach to implementing their ideology, focusing on preaching against the state while working to implement Sharia law within the existing governing structures and providing social and economic services to the community. Much of the change in the Boko Haram movement, its development into the ultra-violent insurgency that it is today, came about after the death of Mohammed Yusuf and the ascension by Abubakar Shekau to the position of leadership and authority he holds today. Shekau's ideology and personality frame all of Boko Haram's actions since Yusufs death, a reality which makes sense in light of the argument that "it is as if every community needs to be renewed and not just carried on (especially through inheritance?), as these religious communities are personal 'inventions', not institutionalized structures” (Last 2012, 15). The idea that these religious communities are personal inventions of their founders and leaders also helps understand the historical individuals whose personal ideologies can still be seen in the ideology that motivates Boko Haram, in particular that of the medieval scholar Ibn Taymiyya.

Ibn Taymiyya was more influential for the development of political Islam than any Islamic scholar before or since. Islamists, including Mohammed Yusuf and Abubakar Shekau, have echoed his sermons and ideologies throughout the years and around the world. Ibn Taymiyya's legacy remains in the existence of an ideology that "is constructed on the concept that a legitimate political authority must be based on the Quran and Sunna (acts) of the Prophet" (Barkindo 2013, 30). All Muslims are duty-bound to work towards the implementation of Islamic law in society as a result, and to question "the validity of secular political authority" as well as "the authority of Muslim but secular political leaders who have failed both in their personal and political lives to uphold correct Islamic ideals" (ibid). 
In developing his ideology of political Islam, Ibn Taymiyya addressed questions about "the exclusion and the non-recognition of other forms of governance" by arguing that all manner of authority — political, religious, or moral — needed a basis in Islamic law and that this foundation was a requirement for the legitimacy of any governing structure or system (ibid 32). Ultimately, for Ibn Taymiyya, "the application of the law of Allah therefore was the only prerequisite for legitimate political authority and the valid means of defending and reforming all societies” (ibid 33).

Boko Haram's insurgency and its attempts to establish an Islamic rule in northern Nigeria, Mohammed Yusuf's earlier work on the implementation of Shariah law, and uprisings by other Islamic communities like the Maitatsine or the so-called Nigerian Taliban all speak to the lasting influence of Ibn Taymiyya's ideology of political Islam. The idea that the members of Boko Haram are acting upon their duty as Muslims to fight for the implementation of Islamic political authority is one of the primary motivating factors behind the insurgency. Indeed, there are audiotapes still circulating around northern Nigeria with recorded sermons in which Mohammed Yusuf quotes Ibn Taymiyya directly; in calling for his followers to stand against the secular Nigerian state, Yusuf compared the nation's political leaders “to the Mongol invaders of Ibn Taymiyya's time” (Barkindo 2013, 36-37). For Yusuf and Shekau, for Boko Haram and those who subscribe to Islamist ideas of political authority and legitimacy, Islam becomes not simply a personal belief system, more than simply a religious community, but an overarching religious, social, moral, and political system of authority.

It is this all-encompassing nature of political Islam that seems to put it at odds with secular, liberal democratic values and governments, and which prompts the idea that Islamic thought and Western thought are in a so-called clash of civilizations. In Western secular liberal democracies, religion is generally (theoretically) expected to be personal and largely practiced in private or within the confines of a church or temple or mosque. For many Muslims, however, particularly within the strains of political Islam and Islamism that have been exerting themselves throughout North Africa 
and the Middle East in recent decades, Islam extends far beyond this limited Western conception of religion. There is not only individual faith, the personal subscription to a theological doctrine, the private moments of prayer and the communal, rituals of worship among likeminded believers. Islamic practice often incorporates these things, but for many Muslims their religion extends further as a way of life, a complete system providing guidance on how a believer should act in the political, social, and economic sectors, although it must be noted that these ideas are also subject to debate and often highly contested amongst Muslims (Lewis 1976; Barkindo 2013; March 2015).

Political Islam has particularly important implications for religious identity and communal solidarity, in the process of civil governance and political authority, and in warfare. While "no single one of Islam's political commitments is unique to Islam," the difference between Islam, especially in its most overt and the Western sense of religion comes from the fact that "no other religious tradition displays all of them together, from political solidarity to a theory of righteous warfare" (March 2015, 17.4). Many Islamists cite the traumas afflicted on the Muslim community through the marginalization of Islam and the oppression of Muslims by Western governments and militaries, "in explaining why Muslims must never accept secularism and the privatization of religion” (March 2015, 17.3-4). As a result, for Islamists, "religion provides both the language of discontent and the logic for political resistance as a moral act" (Last 2012, 32). They subsequently tap into a deep well of historical pain and frustration, just as Mohammed Yusuf tapped into the frustration and alienation of Muslims in northern Nigeria. In doing so, they reinforce the importance of Islamic community and solidarity and provide further proof of the present necessity of Islamic rule in Muslim countries.

On the other hand, there are counterarguments against the importance or validity of political Islam that further cast Islamism and groups like Boko Haram as modernist, even personal, inventions. Some scholars trace the development of the political Islam back to the Medinan Treaty, a pact drawn up by the prophet Mohammed after migrating to Medina because of the persecution he and 
his followers were being subject to in Mecca. The primary aim of the treaty was to guarantee "full autonomy to all tribes and religious groups like the Jews, the Muslims and other pagan tribes," while also stating that "if an outside force attacks Medina all [tribes and religious groups] will defend it together" (Barkindo 2013, 31). What is important to note here, according to this argument, is that the intent behind the Medinan Treaty may not have been the establishment of a political community as the primary governing authority. Instead, Mohammed was seeking the creation of a community that was based in religious faith yet would remain compatible with politics.

The evolution of the Islamic community into one that approached governance and political authority from a religious perspective was incidental rather than imperative. Ultimately, "the fundamental intention of the Prophet was to establish a religious community tolerant of diversity and responsive to political problems, but not a sovereign political authority" (Barkindo 2013, 31-32). In the 1920s, the Islamic scholar Ali Al-Raziq further denied that Mohammed intended for Islam to be a political system as well as a religious one, arguing that the Prophet was the head of "Islam as a religious unit ... and that as head of that unit he preached with word and sword, obtained divine revelation and was aided by divine forces" (ibid 40). But, Al-Raziq would argue, "the utterances of the Prophet made no allusion to an Islamic state or an Arab state," and everything he did was in service to the establishment of Islam as a religion, not as a political structure or system of governance.

Other scholars refute this argument however, countering that the political solidarity of the umma and the shared desire for a governing structure based in Islamic law have been central aspects of Islam from the time of the Prophet through Ibn Taymiyya to the present day. The distinction and the debate on whether or not such a distinction actually exists — between Islam and Islamism is informed by this debate over the importance of politics in Islam. Subscribing to the argument that there was no intention on the part of the prophet Mohammed to instill a political focus within Islam, let alone to create and fight for an Islamic state existing solely under Islamic law, the argument 
follows that Islamism and its extreme political focus is an essentially modern creation. As such, Islamism is — if not wholly separate from Islam — an entirely distinct offshoot, a "cultural-political response to a crisis of failed postcolonial development in Islamic societies under conditions of globalization" (Tibi 2012, 23). Thus Islam is placed within the Western sense of religion mentioned previously, as a private faith, a personal belief in the five pillars and that Allah is the one true god. Islamism, on the other hand, "is about political order, not faith" (ibid 1).

This argument is valid, certainly, in that not all Muslims emphasize the political aspects of the religion as Islamists do; Islam can be a personal and private religion just as it can be a communal and political one. It is also an admirable argument in a way, as it separates the majority of Muslims from those — like Boko Haram — who take an extreme political view. But it is a flawed argument as well, primarily because it is not possible to argue that Islamists are not actually practicing Islam, when they wholeheartedly believe that they are. It also paints Islam as a single entity, a monolith of a belief system with little to no variation worldwide, and it ignores the fact that there have been, at the very least, debates and discussions between Islamic scholars over the political and legal aspects of the religion that date much farther back than the modern Islamist movements (March 2015, 17.6). At the same time, to argue otherwise - to argue that Islamism is Islam in its original and intended form as it was formed thousands of years ago, with an extreme emphasis on political authority — is to risk falling into the realm of a clash of civilizations between Islam and the West, the ancient and the modern, and likewise to risk painting Islam as a monolithic belief system that has marched through the centuries unchanged and unchangeable and in which all Muslims believe in the political authority of Islam and are willing to fight for its implementation.

Unfortunately, a full discussion of political Islam and the distinction between Islam and Islamism is beyond the scope of this project. However, regardless of its exact foundational moment, and regardless of its incidental or essential development into a key aspect of the religion as a whole, 
it is critically important to remember that "Islam does bequeath a powerful political impulse, but this prevents neither Islam itself from changing nor Muslims from assimilating a variety of novel values and desires in politics” (March 2015, 17.4). For some Muslims, Islam has a deep and important political focus. This fact cannot, however, be a justification for further marginalization of Muslims as a whole based on the belief that the existence of political Islam in a world that is largely based in secular democracy means that militant insurgency, like that of Boko Haram, is inevitable. And while it is important to understanding Boko Haram, it is far from being the sole reason for Boko Haram's existence. The debates over political Islam, especially among Islamic scholars, are indicative of the debates that take place around other issues affecting the Islamic community and demonstrate the importance of discourse in shaping the religion.

As has been true throughout the history of Islam around the world, there is a history of opposing discourse among Muslims in northern Nigeria. This often took the form of debate between groups regarding the approach to spreading Islam throughout the region and the legitimization of Islamic authority within or in opposition to the state. Just as there were discussions and debates between Mohammed Yusuf and his one-time mentor, Ja'far Adam, there were debates between Yusuf and Abubakar Shekau when Shekau was one of Yusuf's top deputies. Historical precedent stretched back to the earliest days of the Sokoto caliphate, as "even the founding jihad [of Usman Dan Fodio] had its opponents among the Muslim elite in the Hausa governments of the day and among Muslim scholars who questioned the legitimacy of Muslims fighting Muslims” (Last 2012, 1).

The root issue then, as it is today with Boko Haram targeting Muslims who have committed treason against the umma and betrayed the community, was the question of when it was acceptable to kill a fellow Muslim who has failed or refused to act properly in accordance with Islamic law. Arising out of this particular aspect of the discursive history of Islam in northern Nigeria, "today's 
dissidents, such as the notorious Boko haram, are part of a tradition of dissidence ... neither are they a new phenomenon nor will they be the last of their kind" (ibid, 5).

The tradition of debate, discourse, and dissent in Islam extends throughout the Islamic community and prompts numerous interpretations of various aspects of Islamic law. There is debate, for instance, over whether it is acceptable to rebel against the Islamic authorities in power even when they are considered venal, corrupt, and oppressive. Even sharia, often perceived as a singular set of rules and guidance, has within it four distinct schools of law. And "dissent within Islamic communities depends on what is considered bid'a, innovation," something upon which there is much disagreement among varying Islamic sects or groups (Last 2012, 2). This concept of bid'a or innovation is a significant part of the development of and motivation behind Boko Haram.

Boko Haram's approach to innovation broadly aligns with that of the Islamic communities or groups who refer to themselves as abl al-sunna wa'l-jama'a, evidenced by the fact that Mohammed Yusuf was selected by a group of sheiks to lead a group known as Ablulsunna waljama'ab hijra in 2003. For these groups, even "more mundane aspects of life-such as the use of gadgets like watches or the teaching of modern scientific data (especially where such data are at variance with the knowledge that is given in the Qur'an) - have been regarded ... as wholly unacceptable to any individual or community seriously seeking to replicate in their own lives the lifestyle of the Prophet" (Last 2012, 2). The members of these groups strive for a piety and purity they believe is lacking in modern society. This is why they reject some elements of contemporary daily life and, furthermore, why many of these groups excluded themselves from the rest of society, walling off people and influences from outside their community. Even the governments of secular nation-states are bid'a, innovations with no basis in the Quran or the Sunna, and should hold no power over Muslims.

The Quran strictly forbids bid'a outright, according to members of these abl al-sunna groups. Any compromise or acceptance or tolerance goes against the way set out in the Sunna. It comes as 
something of a surprise then that while Mohammed Yusuf claimed in some of his recorded sermons and lectures that elements of Western education should be forbidden along with certain types of employment within the Nigerian government, his approach was in fact somewhat more nuanced than an outright declaration that bid'a — in particular, Western education, the boko of the Boko Haram name - was forbidden. This is an important distinction to make because generally speaking, descriptions of Boko Haram's ideology often begin and end with its etymology: boko, a Hausa word generally translated as Western education, and haram, an Arabic word meaning sinful or forbidden (Campbell 2013; Adegbulu 2013; Umar 2012; Hansen and Musa 2013; Zenn 2012).

Yusuf regularly claimed that certain elements of Western education were incompatible with Islam, routinely denying the scientific explanation for rain, evolution, the efficacy of modern vaccines, and that the earth is round. But in recorded debates he judged its validity according to "a HadIth that divides Islamic perspectives on any knowledge into three types: 1) knowledge that conforms to the Qur'an and Sunna, which should be accepted; 2) knowledge that contradicts the Qur'an and Sunna, which should be rejected; and 3) knowledge that neither supports nor contradicts the Qur'an and Hadith, which can be accepted or rejected on its own merit or as circumstances dictate" (Umar 2012, 124). Once those elements of Western education that contradicted the Quran and Sunna were removed, the rest of "modern knowledge is perfectly acceptable to his Salafi conception of Islam" (ibid). Accordingly, today the group rarely refers to itself as Boko Haram, preferring instead the name Jama'atu Ablissunnah lidda'awati wal Jihad - "People Committed to the Propagation of the Prophet's Teachings and Jihad" or JAS — or one of several more recent Islamic State-connected names, such Wilayat Gharb Afriqiya or the West African Province (Onuoha 2012, 161; Mainangwa et al 2013, 45). The emphasis on either of these names indicates an ideological scope broader than just a condemnation of Western education. 
Instead, the ideology behind the insurgency is far more political in nature, based in Islamism and the ideas of Ibn Taymiyya, and with one primary goal: the establishment of an Islamic caliphate, separate from the Nigerian state, based on the strict application of sharia law (Adegbulu 2013, 266). Boko Haram's approach to acheiving this goal has largely depended on the individual at the head of the group. But the pursuit of this goal can be seen as an attempt to provide a simple answer to a fundamental question: "If the modern state is unwilling or unable to fulfill its declared functions, what is its purpose, its justification?” (Hansen and Musa 2013, 289-290). For Yusuf and Shekau alike, the answer would seem to be that there is none.

Yusuf demonstrated this in part by establishing social programs and small-scale economic programs to help the poor in Maiduguri. In doing so, he and his followers were "standing in for the secular state and usurping its functions: social services the state was either unwilling or unable to deliver to the impoverished masses" (ibid, 289), a logical first step in making the establishment of an Islamic state seem preferable and desirable. This aligns with the more nuanced approach of some of Yusufs recorded debates in which, much as he argued that Western education may be permissible once the elements which directly contradict the Qur'an and Sunna were removed, he distinguished between employment in sectors of the state government infrastructure which he claims are forbidden to Muslims — in the legislative and judicial branches, and in law enforcement — and those which were permissible, such as in service provision (Umar 2012, 126).

In part, this helped the push for the implementation of Sharia law in twelve northern states in the early 2000s - which Yusuf was directly involved in in Borno - because "among the impoverished and insecure in northern Nigeria whose malnutrition and poverty is amply documented, Sharia promises a popularly legitimated blueprint for a just and secure moral order" (Lubeck, Lipschutz, and Weeks 2003, 19). Being popularly legitimated as it was in the north made Sharia seem to many to be a viable alternative to the secular federal government, the legitimacy of which is often ques- 
tioned, the unpopularity of which is not. It was in this same way that Boko Haram came to be seen by some as a viable alternative, or at least the means to the creation of a viable alternative, to the $\mathrm{Ni}$ gerian state that had consistently failed them. Muhammed Yusuf was able to create an ideological space in which he and his followers could fight for the establishment of an Islamic caliphate by working within the established system, rather than attacking it and attempting to destroy it entirely. That would turn out to be Abubakar Shekau's approach in the years following Yusuf's death.

Underpinned by the political focus of Islamism, the strict prohibition of political innovation characterizing Boko Haram's ideology under Abubakar Shekau returns the discussion to the belief that all "good" Muslims are required to fight: for the implementation of Islamic law, against the oppressive secular government, against erring Muslims and non-believers and pagans (Last 2012, 2-3). There is a sense of rightness or righteousness in the fight against all of these elements of secularism, of bid'a and innovation, that drives the dissidence of Islamic groups in northern Nigeria to pursue their goals through violence even in the face of seemingly overwhelming odds and the ostensibly greater military strength of the state. And when the state uses that military strength in an attempt to suppress or destroy any dissident group, it only fans the flames of the fight, valorizing the Muslims who were killed and vilifying the secular forces bent on destroying the Islamic community.

\section{6-Conclusion}

The leaders and members of Boko Haram were brought up in a region that has a long and complex history, deeply affected by both the religious and political aspects of Islam. There is no shortage of historical parallels between Muslim dissidents of decades and centuries past, and it is crucial that one should draw upon these parallels in order to understand the political-religious milieu of the current insurgency. The introduction of Islam into the region must be acknowledged, for obvious reasons, as the starting point. Ibn Taymiyya's ideas on the nature of Islam and the importance 
of an Islamic authority that would dictate approaches to all facets of life, whether political, cultural, or moral retained their preeminence and influence across centuries and borders until they were taken up again by Mohammed Yusuf. This is fundamental to understanding Boko Haram.

Without the Jihad of Usman Dan Fodio and the establishment of the Sokoto Caliphate as one of the preeminent kingdoms of nineteenth-century Africa, it becomes far more difficult to imagine Boko Haram waging a successful insurgency on the backs of militants painting themselves in Islamic colors. Boko Haram has its place within the broader patterns of Islamic dissent first begun by those who fought against (or distanced themselves from) the Caliphate and other Islamic authority figures, and perhaps more importantly, against the authority of the colonial regime. The increasing importance of religious identities and the efforts of political authorities to create and institutionalize these identities, and to wield them as a form of domination and control, is reflected in the importance that Boko Haram places on its own ideological identity, in the way that its leaders are likewise able to wield that identity as a form of control over the members and foot-soldiers responsible for carrying out the insurgency.

In short, Boko Haram has been deeply affected and influenced — knowingly and intentionally, but also simply by way of existing in a region in which there are larger forces that were set in motion long before the birth Boko Haram — by the historical tactics and strategies of Muslim dissidents, has drawn ideological guidance and strength from medieval and modern scholars, and has been molded by the long-standing importance placed on discourse and debate. There is no denying that Boko Haram has become a major point on the historical timeline of Islam in northern Nigeria. But Boko Haram is not only this history. It is not enough to simply argue that Boko Haram is but a continuation of this history, a present-day manifestation of historical patterns and ancient religious theories or ideologies. Chapter four will further round out the full understanding of Boko Haram and its insurgency that is the goal of this project. Before that, however, the next chapter examines 
the group and the insurgency itself, providing an overview of how — as well as through and against whom - Boko Haram became not only that major point on the timeline of Islam in northern Nigeria but a fundamental turning point in the history of the country as a whole. 


\section{Chapter 3 \\ The explosive contours of Boko Haram}

Unprecedented violence has characterized northern Nigeria for the better part of a decade. Hundreds of thousands of innocent civilians have been swept up in a chaos of bloodshed and terror, entire villages razed to the ground as the numbers of people killed and maimed, wounded physically and psychologically, displaced and desperate continue to rise. Boko Haram has been at the center of it all, though it has not been fully responsible for each and every tragedy. Having established the foundational history of Islam, dissent, political and religious ideology and the importance of religious identity that informs any complete examination of the crisis in northern Nigeria, this chapter continues to construct an understanding of Boko Haram as it developed over the years into a force capable of shaking the foundation of Nigeria as a whole.

Broken down into five sections, this chapter begins with the foundations of Boko Haram, bringing the work of the chapter two into more present times and examining a number of prior insurgencies that took place in the region and the antecedent groups which preceded Boko Haram. In sections two and three, the lives, ideologies, and rhetoric of Boko Haram's two primary leaders Mohammed Yusuf and Abubakar Shekau — provide context for the developments the group and the insurgency occurring under the authority of each man. Though Yusuf and Shekau are primarily responsible for the ideological development and tactical and strategic maneuverings of Boko Haram,

they remain highly dependent upon the group's members and supporters. As such, their recruits and soldiers, the monetary funding and supply of matériel, ties to similar-minded international groups, and varying factions within Boko Haram become the focal point of section four. The actions - major attacks, raids, kidnappings, and assaults along with the increasingly sophisticated tactics they involve - largely set in motion by Yusuf and Shekau and carried out by Boko Haram's soldiers are detailed in the final section. Additionally, this section will examine some of the major acts of vio- 
lence perpetrated by state forces against militants as well as civilians, ending with the current state of Boko Haram and its fight against the Nigerian state.

Through these sections, this chapter builds upon the foundations of an ideology established in chapter two and analyzes how those foundational aspects have come to play out in the present day. The actions of Boko Haram, the scope of its insurgency, and its development from a grassroots organization providing social services in lieu of the state to an exceedingly violent militant campaign entirely unrestrained in its brutality have shaped the reality for hundreds of thousands of people. A full examination of all of these facets is crucial to a complete understanding of Boko Haram and the crisis in northern Nigeria.

\section{1 - Geography, foundations, and antecedent groups}

Nigeria is broadly divided between Islam in the north and Christianity in the south. The two meet in the Middle Belt of Nigeria, a "fault line" that bisects the country roughly equally as it runs east-west (Campbell 2013, 44). And while the country as a whole has weathered conflicts cloaked in terms of religious clashes throughout the years, there is also a significant amount of interfaith cooperation and healthy economic competition within the dominant informal economy, indicating that tensions between Muslims and Christians as a whole are likely not as high as they might seem in light of these religious conflicts (Meager 2013).

For northern Muslims, the northwestern region, formerly ruled by the Sokoto Caliphate until its conquest by the British, is to this day often considered the preeminent base of Islam in Nigeria. Close behind in historical importance is the sultanate of Borno, which was established in the early twentieth century but has roots as far back as the Bornu Empire of the eleventh century. Located opposite Sokoto in Nigeria's northeastern corner, the sultanate remains based in the city of Maiduguri today. With such a rich history of Islamic authority and thought, it makes sense that, according 
to most scholars, Maiduguri was the birthplace of Boko Haram as well (Campbell 2013, 48). And though Maiduguri is still most closely associated with Boko Haram and generally accepted as its original home, Yobe State, situated directly west of Borno, has also been identified as the group's headquarters in years past (Aghedo and Osumah 2014, 5). This may have been true at one point, but the uncertainty is indicative of the loose grasp on who and what specifically constitutes the core faction responsible for most of the violence versus others that fall under a broader umbrella of the Boko Haram name but have split off and eschew violence, especially against other Muslims.

From early 2014 through the end of 2016, Boko Haram established itself in the Sambisa Forest (Kayode 2014; Oladipo 2015; Al Jazeera 2016a). A sixty thousand square kilometer expanse of short trees and thick brush, Sambisa is located roughly sixty kilometers southeast of Maiduguri. Originally marked out as a game reserve by the British colonial authorities, the forest was incorporated as part of the Chad Basin National Park in 1991. While dozens of villages surround the outskirts of the forest, the designation as a game reserve and later as part of a national park has allowed the interior to remain largely untouched and unsettled — in short, an ideal place for Boko Haram to establish a stronghold.

The dense, particularly thorny vegetation makes it difficult for large military forces to traverse on foot or by vehicle while the short, broad trees provide cover from aerial surveillance. Rumors that Boko Haram has constructed "super bunkers" beneath the forest in which to hide out from military advances are almost certainly untrue, but the forest has proved highly useful to the group, a significant factor in the duration of its insurgency. Outside of its stronghold in Sambisa, few reports claim anything regarding a primary base for Boko Haram in late 2016 or early 2017. Boko Haram activity continues in numerous locations around the northeastern region, the most recent of which has been concentrated near the Cameroonian and Chadian borders (Searcey 2017), despite 
President Muhammadu Buhari's assertion in late December 2016 that "the terrorists are on the run, and no longer have a place to hide" (Al Jazeera 2016a).

Regardless of the exact location of its main base of operations, groups identified as or associated with Boko Haram exist in Kano, Kaduna, Zaria, and numerous other towns and cities across northern Nigeria, extending as far as the seat of the federal government in Abuja (Onuoha 2012, 161). In its attacks and raids, detailed in depth in section five, Boko Haram extended its geographical range since 2009, operating not only across northern and north-central Nigeria but transnationally as well, moving into the neighboring nations of Chad, Niger, and Cameroon. Despite attacks in multiple states and the increase in attacks in neighboring countries, through the second quarter of 2016, "nearly three-quarters $(22,928)$ of Boko Haram related deaths [had] occurred in Borno State, which is home to only three percent of Nigeria's population" (Allen 2016).

Boko Haram began gaining widespread notoriety in 2009, but again the history of violent insurgency in Nigeria extends much farther back than the early twenty-first century. Those patterns and expressions of dissent among Muslims traced through the nineteenth and early twentieth centuries gave way to similar actions by both Muslims and Christians, as well as militant groups for which religion had little influence on their grievances, after Nigeria gained its independence. The increasing threat militant groups posed to the stability of the country was recognized by some as early as 1995 , when a prominent member of the northern elite issued a warning, arguing that "If we do not nip this thing in the bud now, we may end up with a revolution which is not just religious, but may be political, social and economic. Symptoms of revolt look large on the horizon today" (Maier 2002, 170). Unfortunately, if this warning was not entirely ignored, it still did little to assist in the state's response to this developing threat.

In part because of this complex history of dissent and militant insurgency, scholarly opinion differs significantly on the precise modern genealogy of Boko Haram and the antecedent groups 
from which it arose. Some scholars trace the ideologies and evolution of Salafist Islam (from which Boko Haram draws much of its religious language, which will be examined more later) to the end of the civil war in 1970, and the influence of more ancient scholars like Ibn Taymiyya has been documented. The more common tendency is to view Boko Haram as an offshoot or outgrowth of the Yan Tatsine, and Islamic sect responsible for the instigation of violent riots in a number of northern cities in 1980 (Agbiboa 2014, 53; Campbell 2013, 54; Onuoha 2012, 162).

Based in Kano, the Yan Tatsine were the followers of Maitatsine, a Cameroonian Muslim scholar who declared Western education, clothing, and so-called innovations such as the bicycle to be forbidden to Muslims (Murtada 2013, 7). Indeed, the uprisings of the Yan Tatsine - commonly known as the Maitatsine riots — share with Boko Haram an ostensible goal of protest against Muslim elites seen as rich, corrupt, and "un-Islamic." In contrast to that of Abubakar Shekau however, there was no state-building element to Maitatsine's rhetoric, and the violent protests of the Yan Tatsine seemed only to be just that. The incorporation of certain aspects of local animist religions into Maitatsine's ideology further distances him and his followers from Boko Haram, and there do not appear to be any known connections that would directly link Maitatsine to Mohammed Yusuf (Campbell 2013, 54).

There may likely be direct connections between Yusuf and Ibrahim Zakzaky (or Zakzaki), however (detailed in section two). A Muslim preacher from the northern city of Zaria, Zakzaky began to rise to prominence around the same time as Maitatsine largely through sermons "known for their emotional rhetoric and enthusiasm against the Nigerian state" (Murtada 2013, 5). Today, Zakzaky is the leader of the Islamic Movement of Nigeria (IMN), a group formerly known as the Mus$\lim$ Brotherhood — though unrelated to the Egyptian political party of the same name — and often referred to simply as Shiites because of the branch of Islam they subscribe to and the fact that the vast majority of Nigerian Muslims are Sunni (ibid; Gaffey 2015). The IMN has similar ideological 
roots as the violent but short-lived Nigerian Taliban and Boko Haram, striving "to ensure more stringent application of Islamic legal and administrative systems... [and] ultimately to create an Islamic state in Nigeria" (ibid).

Among Nigeria's Shi'a minorities, the members of the IMN “appear to be particularly detested by the North's Islamic establishment, not least because of their ability to stir up popular urban unrest" (Campbell 2013, 57). Although Zakzaky was arrested again in December 2015 after clashes between his followers and the Nigerian military — a situation that parallels the events that led to Mohammed Yusuf's death — he continues to publicly reiterate the IMN's commitment to nonviolence (Gaffey 2015), putting him at odds with Boko Haram despite their similar goals of establishing an Islamic state. It is entirely possible that Zakzaky's followers, despite persecution by state forces, have not responded with violence like that of Boko Haram because their leader was not martyred by state forces like Yusuf was, the trigger for Boko Haram's turn towards violence.

Other genealogical examinations trace the group's origins to 1995 , the beginning of what could be called the "latent incubation stage" of Boko Haram (Onuoha 2012, 162). From 1995 to 2002, the Nigerian government monitored an Islamic group commonly known as Ablulsunna wal'jama'ah hijra. When it began gaining traction in Borno State in the latter half of the 1990s, the group "was committed to moderating orthodox Islam, [and] never adopted any form of violent strategy in the propagation of its ideology" (ibid). That changed in 2002, however, when it began to split and splinter into varying factions, a number of which increasingly advocated for the necessity of violence in advanced their agenda.

During the same time period, between 1998 and 2000, twelve northern states officially adopted Sharia law (Campbell 2013, 132-133). However, among many people who had called for a strict application of Sharia, there was growing disillusionment with the local state governments that banned punishments such as stoning and amputations. It was within two years of the implementa- 
tion of this moderated form of sharia that the Nigerian Taliban (which appears not to have any relation to the more well-known Taliban in Afghanistan, beyond the obvious reverence which led to the adoption of the name) emerged in Borno State, again based in an ideology that was Salafist in origin and violent in practice similar to that of the IMN and, later, of Boko Haram. When military forces ultimately suppressed the Nigerian Taliban, many of its members faded back into the general population, a recurring trend that speaks to what may be a sense of popular support for insurgent groups in the region including, in its earlier iterations, Boko Haram.

In the midst of this confluence of the IMN and Shiites, Ablulsunna wal'jama'ah hijra and the Nigerian Taliban, a preacher named Mohammed Yusuf — the first leader of Boko Haram and generally regarded as its founder — began his rise to a prominence.

\section{2 - Boko Haram under Mohammed Yusuf}

Much of the background information commonly used to create a portrait of Mohammed Yusuf - as a human being with an actual past made up of formational experiences and relationships, and not just a preacher who inspired the most devastating militant insurgencies in Nigerian history — is unconfirmed. So much so that even his ethnicity remains in question (Campbell 2013, 133). However, there are a number of assertions that have gained a veneer of fact through repetition. He was born in Yobe State around 1970. He had a lavish lifestyle in Maiduguri, driving around the city in a white Mercedes-Benz despite the vast majority of his followers living in poverty, possibly indicative of connections to and support from certain members of the political and economic elite. And, most importantly, he was a fiery and charismatic preacher capable of commanding the attention of large audiences (Campbell 2013; Onuoha 2012; Umar 2012).

There is still less consensus regarding his educational history. Some reports state that after dropping out of secondary school in Nigeria, he went on to receive an Islamic education in schools 
in Chad and Niger (Onuoha 2012, 163). Others claim that he was "very well-educated in a Western context," having completed graduate-level studies though in what sort of concentration, it is unclear (Boyle 2009). If his own claims are to be believed, he received no formal education whatsoever, not secular or religious, Western or Islamic (Umar 2012, 122).

Perhaps more important than his childhood and family, his formal education or lack thereof, are Mohammed Yusuf's possible — but again unconfirmed — roots within ostensibly non-violent sects. In 1980, he may have joined the ranks of the Shiites, the followers of Ibrahim Zakzaky and his public denunciations of violence (Murtada 2013, 5). In 2003, a committee of sheiks elected Yusuf as the leader of the Ablulsunna wal'jama'ah bijra sect — another sect that, as mentioned previously, had never incorporated violence into its doctrine nor used violence as a strategy (Onuoha 2012, 163). Many other groups, influenced by the same wave of thinking as Zakzaky and Ablulsunna wal'jama'ah bijra, chose to distance themselves from mainstream society and practice quiet piety. Many of these groups were, like Yusuf, based in Maiduguri and it is highly possible there was debate and dialogue between the two (Campbell 2013, 56).

Indeed, with Yusuf's guidance, the Ahlulsunna wal'jama'ah hijra sect "strove for self-exclusion of its members from the mainstream corrupt society by living in areas outside or far away from society" (Onuoha 2012, 163). Between 2002 and 2004, Yusuf split from his mentor Ja'far Adam — leader of the non-violent Izala movement that encouraged Muslims to work for change within the state apparatus rather than outside of it or by overthrowing it - and his influence within Ablulsunna wal'jama'ah hijra continued to grow. It was around this time that members of the sect became more commonly known around Maiduguri as the Yusufiyyah — the followers of Yusuf. And it was the Yusufiyyah that would later become Boko Haram (Mustafa 2014, 12), exchanging their initial avoidance of outright clashes with state forces for unrestrained violence against state forces and civilians alike after Yusuf was killed in police custody. 
Yet again, however, contrasting reports indicate the direct involvement of Yusuf's followers in violent confrontations even prior to being known as Boko Haram. In December 2003, a detachment of police officers was sent to investigate reports of conflict between villagers and a group of Yusufiyyah. But the Yusufiyyah repelled them and one police officer and two villagers were killed. Immediately following this skirmish, Yusufiyyah advanced on the police station, looting weapons and ammunition and burning down the station (Umar 2012, 127). Ties between Yusuf and the violent Nigerian Taliban have also been reported (Onuoha 2012, 163-164), but this may be due to confusion or misidentification of the individuals involved in confrontations with police and the military (Umar 2012, 128). Furthermore, while Yusuf may have believed that preaching and mobilization of people, rather than violence, could lead to the creation of an Islamic state based on sharia, Abubakar Shekau, Yusuf's top deputy at the time, repeatedly argued otherwise, both to Yusuf and to their followers (Campbell 2013, 133).

Shekau's arguments were likely more compelling to some of the Yusufiyyah than those of their leader, and prepped them for violence even while Yusuf himself continued to believe in the possibility of a non-violent solution. However, whether or not Yusuf believed that achieving his goals was possible through non-violence or how strongly he may have held onto this belief is less important than the fact that there was impassioned debate and dialogue between individuals educated in their field - not simply an ideological belief in the necessity of violence. The subsequent turn toward violence was not an inevitability built into the fact that Yusuf and Shekau and their followers were Muslim or Salafist: cloaked in religious language as it was, it was in actuality a calculated response to numerous non-religious factors outside of their religious ideology.

At any rate, apart from isolated skirmishes with police, the Yusufiyyah remained largely nonviolent until the events of July 2009, noted by multiple sources as the tipping point that began the 
transition from Yusufiyyah to Boko Haram (Aghedo and Osumah 2014; Campbell 2013; ICG 2014; Murtada 2013; Onuoha 2012; Osumah 2013; Umar 2012).

In early 2009, the Nigerian government instituted a law requiring helmets to be worn while operating motorcycles, and the governor of Borno state instructed police to enforce the law as part of a project called Operation Flush. On June 11, 2009, a congregation of Yusufiyyah was making their way through Maiduguri to a funeral for one of their members when one of the followers was stopped by security forces for riding a motorcycle without a helmet. There are two accounts of what happened next, from the government's Administrative Committee of Inquiry and from Mohammed Yusuf, both quoted at length by Umar (2012, 128-129).

According to the Administrative Committee, Yusufiyyah approached and surrounded the security forces and attempted to forcibly disarm them. The members of the security forces reacted in self-defense, targeting the legs of Yusuf's followers as they opened fire. In his own recounting of the incident, Yusuf ignored any build-up to the confrontation, claiming that security forces, entirely unprovoked, simply opened fire on his followers. He went on to list the injuries sustained by his followers; to emphasize the randomness of the injuries as indication that security forces were firing indiscriminately into the crowd, even shooting some of his followers in the back as they fled; and to accuse the government of instituting Operation Flush to "create obstacles for our brothers or for our preaching, and to humiliate ordinary people" (ibid, 129).

With brutal harassment of civilians by security forces a common occurrence throughout Nigeria and in northern cities in particular, Yusuf appears to have been rallying popular support to his side and against the state security apparatus. Indeed, Yusuf ended the sermon in which he gave his account of the events with strident claims that he would not accept what had been done to his followers and with a set of instructions for them: "1) prepare to donate money and blood because both would be required to treat the injured, 2) strictly follow any orders even if they will die in obeying, 
and 3) do not do anything unless they have been told to do it, even if they will die" (ibid, 130). Finally, he gave the government 40 days to respond with a resolution; if they did not, he declared that “jihadi operations will begin in the country which only Allah will be able to stop" (Murtada 2013, 8).

Unsurprisingly, then, fighting erupted across five northern states in late July 2009, though it was most heavily concentrated in Bauchi and Borno states. Between 800 and 1100 people were killed including police, military, civilians, and Yusuf's followers (Onuoha 2012, 164; Umar 2012, 128). The military was forced to intervene when the fighting could not be contained by police forces alone; a coordinated military raid on the main Yusufiyyah compound in Maiduguri ended the fighting for the time being (Hansen and Musa 2013, 286). Along with the casualties, more than 3,500 people were displaced and hundreds arrested, including Yusuf (Murtada 2013, 8; Umar 2012, 128).

Yusuf died in police custody. Officially, police reported that Yusuf was shot and killed while attempting escape. However, it is more likely that police killed him in a form of summary justice arising out of frustration with his "apparent immunity" having previously been "arrested numerous times but always released, presumably because of the intervention of his politically powerful friends" (Campbell 2013, 133). Others believe his death was retaliation for the violent attacks attributed, correctly or not, to his followers in the past (Onuoha 2012, 164). Video of Yusuf's death was captured via cell phone and broadcast widely across northern Nigeria, a critical development in the foundation of the insurgency. The footage shows security forces repeatedly discharging their weapons into Yusufs handcuffed corpse, already riddled with bullets by that point, before instructing captured civilians to lie face down on the ground and executing them with gunshots to their heads and backs (Umar 2012, 131; Maiangwa et al 2013, 47).

This is the primary and most obvious example of the state's complicity in sparking the insurgency. It is little wonder that Yusuf's followers were galvanized in their hatred of the police, military, and security forces, all of whom were, to the vast majority of the population, the face of the Nigeri- 
an state and therefore of oppression and violence, or that many of Yusuf's followers threw their support behind the man who had consistently argued for violent response to the state, Abubakar Shekau (Campbell 2013, 133). And it appears that it was at this point that Ablulsunna wal'jama'ab hijra became known officially as Jama'atu Ablissunnah lidda'awati wal Jihad (JAS) — "People Committed to the Propagation of the Prophet's Teachings and Jihad" — and that the Yusufiyyah became commonly known as Boko Haram (Onuoha 2012, 161; Maiangwa et al 2013, 45).

\section{3 - Boko Haram under Abubakar Shekau}

If little is known for certain about Mohammed Yusuf outside of his sermons, lectures, and interviews, even less is known about his successor and the current leader of Boko Haram, Abubakar Shekau. State security forces originally believed that Shekau had been killed during the fighting of July 2009 - until he emerged to appear in a number of videos released several months later in which he reiterated his violent principles and goals (Campbell 2013, 133; Murtada 2013, 10). Though few of the scholarly works reviewed for this paper mention him by name, he is the current leader of the most prominent sect utilizing the Boko Haram moniker and has become the face of Boko Haram, especially in the wake of the April 14, 2014 kidnappings.

According to a report by the ICG (2014), Shekau was born in Yobe State, on the border with Niger from where his parents may have emigrated into Nigeria several decades ago; he is perhaps slightly older than Yusuf, at somewhere between 35 to 44 years of age (Campbell 2013, 132). He is a member of northeastern Nigeria's largest ethnic group, the Kanuri, a connection that, along with long and porous borders, seems to allow him to travel repeatedly between Niger, Cameroon, and Nigeria (ICG 2014). Shekau's education and training background is also based largely on conjecture. In most of his videos, he speaks only Hausa and Arabic, and appears to have little formal education outside of Koranic studies (Campbell 2013, 134); however, he has since begun to include the 
occasional English sentence in videos released to reporters (BBC 2014). In interviews with people who may have known him, some state that he moved in Maiduguri in 1990 where he studied under a traditional cleric before entering Borno State College of Legal and Islamic Studies (BOCOLIS), a prestigious institute of advanced Islamic studies. It was during his time at BOCOLIS that Shekau was befriended by Mamman Nur — whom Nigerian authorities state was the mastermind behind the August 2011 bombings of the UN building in Abuja — who subsequently introduced Shekau to Yusuf (ICG 2014, 19).

Relations between Shekau and Yusuf seem to have been tense. While Yusuf was a charismatic preacher, it has been reported that he was not a strong leader and had trouble keeping his deputies — and especially Shekau — in check. In 2002, Shekau may have "accused Yusuf of being too soft" and led a splinter group of some 200 of Yusuf's followers into Yobe State. Frequent clashes with local villagers forced the group to continually move, however, and Shekau and Yusuf were ultimately reunited (ICG 2014, 9-10). As noted previously, however, the two continued to argue frequently over the use of violence prior to the events of June and July 2009.

While Nur and Shekau both became close with Yusuf and were considered his top deputies, it may in fact have been Nur whom Yusuf would have chosen to lead the group: Nur was seen as "more knowledgeable, mature and level-headed ... but Shekau was chosen [to lead the group] after Yusuf's death because he was more radical and aggressive” (ICG 2014, 19). The misconduct of police forces and their responsibility for Yusuf's violent death foretold the selection of the more radical, aggressive Shekau, making it all but inevitable. Indeed, it was likely his violent rhetoric, bolstered by several narrow escapes from death that contributed to a sort of mythology that surrounded him, which prompted many of the Yusufiyyah to "acknowledge the spiritual primacy of Abubakar Shekau" (Campbell 2013, 131) and to look to him for "spiritual leadership" (Onuoha 2012, 165). 
Under Shekau's leadership the group has “grown more ruthless, violent and destructive and less open to dialogue" (ICG 2014, 19) as he has done away with Yusuf's approach of working within the state when able to do so while still advancing the agenda of Islamic authority. The increasing audacity and violence of the insurgency however, exemplified by the UN bombing of 2011 and the mass abduction of April 2014 appears to have opened schisms within the group. As early as July 2011, one faction of Boko Haram calling itself the Yusufiyyah Islamic Movement (YIM) distributed leaflets to the media, government officials, and throughout Maiduguri attempting to distance themselves from Shekau's version of Boko Haram.

As reported by the Vanguard newspaper in Nigeria, YIM leaders wrote that they were "concerned that some people with evil motives have infiltrated our genuine struggle with a false holy war that is outright un-Islamic," and that they condemned Boko Haram and any "attacks on the civilian population or places of worship" (Idonor and Marama 2011). (It is interesting to note that they did not seem to denounce violence outright, however. Instead, they felt it necessary to distinguish themselves from Boko Haram because of "genuine concern by individuals and groups to the mass suffering of innocent citizens caught in the crossfire between our members and the Nigerian troops." Unlike Boko Haram, the leaders of YIM wrote, "ours is a clear fight for the blood of our founder, Mohammed Yusuf, and other leaders who were slain in cold blood" and as such, they had "resolved to wage a struggle between justice and injustice, between truth and falsehood, right against wrong, in which the sect was sure of victory (ibid)." In other words: Boko Haram is wantonly slaughtering civilians, people are blaming us for it, and we want to set the story straight, because our fight is a just one against the state machinery which executed our leader and other members of our sect. The one concession of the YIM leaders, however: "Finally, we have resolved to temporarily halt our fight against the assassination of our leaders in compliance with the prohibition of fighting in the holy month of Ramadan” [ibid].) 
Further reports indicate some of Yusuf's former followers are growing weary of any bloodshed at all regardless of its direction towards civilians or to those responsible for the death of their former leader, while the April 2014 abductions drew criticism even from the al-Qaeda leadership to which Shekau had hoped to attach himself (ICG 2014, 21; Nossiter and Kirkpatrick 2014). As such, Boko Haram remains diffuse, and has perhaps grown increasingly so as "in the last four years it has split into many factions with varying aims, to the point that some believe it is too fragmented to present a common front for dialogue" (ICG 2014, 22). However, of the main active factions of Boko Haram - which number between two and six, depending on the report — it is Shekau's which remains the largest in number of fighters and has achieved the greatest success as it continues to be responsible for the most audacious and violent actions of the last few years (ibid).

Shekau's tenure as the leader of Boko Haram has seen the group expand its geographical reach across the borders of neighboring countries, gain widespread notoriety including in the United States and Europe (however briefly the attention lasted), and align itself with ISIS and al-Qaeda in the Islamic Maghreb, on top of the loss of lives and livelihoods and homes to the violence of the insurgency. The geographical expansion of the insurgency alone grew Shekau's reputation to grow over the years, but it was further bolstered into somewhat mythic proportions by the number of times he was reported dead only to release a defiant video weeks or months later. Reported dead in July 2009, Shekau released a video in July 2010 in which he admitted that he had in fact been shot in the leg during the clashes that preceded Mohammed Yusuf's death, but that he was most certainly alive and was claiming leadership of Boko Haram from that point on. Shekau was again reported dead in August 2013, September 2014, August 2015, and August 2016, he released videos in the months following each of these reports, defiantly claiming his health and mocking the military's efforts to find and kill him (Akinyelure 2016). 
Despite his video demonstrating proof of life however, it would seem that Shekau's grip on the mantel of authority over Boko Haram may have grown shakier since the most recent report of his death. After Boko Haram's declaration of allegiance to the Islamic State was accepted in March 2015, Shekau tried to bring the two groups closer together. In doing so, however, it would seem that he managed to alienate a number of other high-ranking leaders of Boko Haram who broke away from Shekau with about half of his followers "because they were not happy with the amount of buyin, if you will, from Boko Haram into the ISIL brand” (Gartenstein-Ross and Zenn 2016).

On the other hand, Shekau alienated himself from the Islamic State leadership as well, who declared in August 2016 that the new leader of the Nigerian faction would be Abu Musab alBarnawi - the son of Mohammed Yusuf. In the statement declaring this change in leadership, Shekau was declared to be too "erratic" and his followers too "independent" to be aligned under the banner of the Islamic State. Shekau released a rebuttal shortly afterwards in which he acknowledged the change in leadership, but claimed that he was taking back his role as the leader of the JAS, Boko Haram's original name. He also reiterated his allegiance to the Islamic State and to Abu Bakr alBaghdadi, claiming that al-Barnawi was attempting to undermine the connection between Boko Haram and the Islamic State and was trying to instigate a coup within Boko Haram itself (ibid). In the end, Shekau declared that neither he nor his followers would support al-Barnawi, and it remains "unclear to what extent Shekau or Barnawi has power over Boko Haram militants" (Stanford 2016). In reality, it is likely they both do.

\section{4 - Recruits, Members, Sponsors, and Supporters}

Boko Haram draws most of its recruits and members from amongst the large and quickly growing population of impoverished and unemployed youth in northern Nigeria. While young men and boys have been recruited from across the region, the majority have been drawn into the group 
from Maiduguri, which in addition to being the birthplace and erstwhile headquarters of Boko Haram, "has been well known in the Islamic world for centuries as an education center famed for its madrassahs and Islamic learning" (Hansen and Musa 2013, 289). The number of recruits drawn from Maiduguri is largely because it is common for families across the northern states to send children to the city as almajiri.

The term almajiri was originally used to describe "someone who leaves his or her home in search of knowledge in Islamic religion" (Onuoha 2012, 161), and the almajiri educational system dates back centuries, with variations found throughout the Islamic world, from Nigeria to Pakistan and across Central Asia (Awofeso, Richie, and Degeling 2003). There are a number of reasons that would lead a family to make the decision to send a child away as an almajiri. Maiduguri's reputation for Islamic learning has drawn prospective students for centuries, and for some families an Islamic education may be the only reason to send a child away from the village. For some, it may not be an Islamic education specifically, but any education at all: even in the villages, government schools are often prohibitively expensive and families may only be able to afford schooling for one child, if any. More often than not, however, there are economic and financial reasons as well. Children are sent as almajiri because of the perception that a larger urban center might provide a better opportunity to find a source of income, if not necessarily employment. And fewer children in the village mean fewer mouths to feed at home.

Upon their arrival in Maiduguri, however, almost all of these students - a label which, in many cases, seems to be used in perhaps the most loosely defined sense, as their religious training often consists solely of rote memorization of hundreds of Qur'anic verses at a time while presided over by a mallam or instructor who wields a whip but has little Islamic education of his own — some of whom are as young as four years old, end up in squalor and poverty. When not memorizing verses, they are forced to spend much of their days begging for food for themselves and money to hand 
over to the mallam. At night they sleep on dirt floors in cramped shacks throughout the city. As a result, the term almajiri — once something rather honorable, depicting a scholar in search of knowledge and Islamic growth — has begun to be used simply to describe "street children" (Adegbulu 2013, 266; Taiwo 2014; Economist 2014).

Because of their precarious position, the almajiri are generally described — at times in denigrating language — as particularly malleable to the cause of Boko Haram. A number of reasons are given for this susceptibility. It may be because these children have been "denied parental care" and find some sort of father-figure in the older members of Boko Haram (Onuoha 2012, 161). It may be because they have "no future to speak of" as productive members of society (Hansen and Musa 2013, 289). The ones who join Boko Haram may be "bound together by a common Islamic sensibility, inchoate rage, and the prospect of earning a little money as terrorists" (Campbell 2013, 130). Or, in a more sinister possibility, they may have "been deliberately bred in the Islamic schools, nurtured, sheltered, rendered pliant, obedient to only one line of command, ready to be unleashed at the rest of society" (Mainangwa et al 2013, 45).

Within each of these lines of reasoning, the almajiri are seen not as individual persons, each of whom has a sense of personal agency and a unique background and mindset which would affect their possible susceptibility to the lure of Boko Haram. Rather, they become an archetype through which arguments regarding relative deprivation and frustration-aggression theories may be made real. It is true that former almajiri make up much of the ranks of Boko Haram, but it is unfortunate that because of this, almajiri as a whole are reduced to broad sketches of future religious extremists, children and young adults hailing from across northern Nigeria stripped of any sort of individual historical context or personality or humanity.

A life spent in flux, sent away from one's family and home only to wind up begging on the streets certainly has major psychological consequences and in many cases makes almajiri more likely 
to join Boko Haram. But there is far more nuance and humanity to their lives and personalities than blanket explanations of common Islamic sensibilities, as though all northern Nigerian Muslims would respond to circumstances in the same way, or the use of animalistic terminology that has children being deliberately bred before they are unleashed at the rest of society. There is nothing to be gained through these sorts of descriptions that firmly establish Boko Haram members — and almajiri in general — as somehow both typically Muslim and something less than human.

Instead perhaps a greater sense of nuance and complex humanity can be gleaned from recognizing the extent to which Boko Haram members have been "unmoored from virtually any certainty about themselves or their world [and] the extent to which all aspects of their lives were made available to forces larger than themselves" (Hoffman 2011, 106). Rather than circumscribed objects whose actions are a result of a common religious rage or years of breeding, almajiri are more likely to be malleable to the rhetoric of Boko Haram because of that lack of certainty. That sense of instability has arisen from and is perpetuated by complicated historical and political contexts. The members of Boko Haram should be understood within this search for certainty and stability, a way to anchor oneself in the world and to establish personal spheres of influence amidst the chaos set in motion by those larger forces. The susceptibility to Boko Haram of many almajiri likewise should be understood as an outgrowth of "the creative potential (as well as devastation) that this deterritorialization of life itself unleashed" (ibid). In short, Boko Haram's ideology provides a cognitive map for those in desperate need of one.

Ultimately however, regardless of the language used to describe the almajiri and the lenses through which their circumstances are viewed, the fact remains that Boko Haram has found a fertile recruiting ground among the young and marginalized of northern Nigeria, almajiri or otherwise. In 2012, some reports put the group's total membership at some 280,000 (Adegbulu 2013, 266; Onuoha 2012, 161). In 2013, the US Department of State listed membership in the range of hundreds to 
thousands (essentially somewhere less than ten thousand), while in 2014, the Combating Terrorism Center at West Point listed between fifteen to twenty thousand (Stanford 2017). The true number is likely unverifiable and hard statistics are difficult to pin down because of the nature of the conflict, the group's ability to attack and then disappear back into Sambisa Forest, and the recurring theme of possibly innocent individuals being labeled — and often arrested and imprisoned — as members Boko Haram without evidence. The number of Boko Haram members does not necessarily equate with the number of Boko Haram soldiers, and the splinter groups and varying factions that exist underneath the Boko Haram name likely also accounts for some of the variation in these numbers.

Additionally, the various numbers of Boko Haram members that have been reported do not necessarily equate to the number of soldiers carrying out — or even being actively willing to carry out — attacks, raids, and assaults. This is an important distinction, especially in examining Boko Haram's earlier years prior to Shekau's turning the group toward indiscriminate violence, because at one point, Boko Haram did in fact enjoy a certain measure of popular support. Various scholars, analysts, and media outlets argue that despite, or perhaps because of, its violent clashes with military and police forces, Boko Haram under Mohammed Yusuf had a rather strong base of popular support among Northern Nigerians. That support may have been engendered by Boko Haram's ability to "[tap] into the very real governance, corruption, and underdevelopment grievances shared by most people in northern Nigeria, create a vicious circle whereby violence and destruction create additional unemployment and, thereby, new recruits" (Looney 2014).

The extremely heavy-handed violence of the Nigerian military and police forces would also help create a base of support for those who would stand in opposition. Many people in the north view these government personnel as "being just as predatory and disrespectful of their civil liberties as Boko Haram has been," and there is a "deep disaffection underpinning support for Boko Haram which began as an anti-government movement focused on anger over poverty and corruption" 
(McGreal 2014). And there may be additional evidence for the popular support of Boko Haram in the ability of some Boko Haram members to carry out attacks and then seemingly disappear back into society undetected by — or hidden from — security forces (Campbell 2013, 133-135; Hansen and Musa 2013, 290).

More recently, however, whatever popular support Boko Haram may have had under Mohammed Yusuf and during its initial campaigns against government forces beginning in 2009 appears to have largely if not entirely dissipated in the years since. This is primarily because of the direction in which Abubakar Shekau has taken the insurgency, with attacks directed at the general population and recruitment strategies that have changed from voluntary enlistment to kidnapping or forced conscription. The number of individuals being recruited willingly into Boko Haram has tapered off significantly since the insurgency's violence has increased, and the majority of new members the group has gained in recent years have been forced to join through the threat of violence and death. In June 2013 for example, residents of Bama village in Borno state fled amid threats that Boko Haram would behead anyone who refused to join (ICG 2014, 17).

Abducted women and girls have become "brides" or sex slaves for Boko Haram members, and are increasingly being used as suicide bombers. A girl as young as ten years old was used as a suicide bomber in a January 2015 attack that killed more than twenty people in a market in Maiduguri (Nossiter 2015). The mass abduction of secondary school girls in Chibok in 2014 was widely condemned around the world and even by members of al-Qaeda (Nossiter and Kirkpatrick 2014). The most striking evidence of the loss of popular support for Boko Haram — as well as a powerful indictment of the failure of the military and police response to the crisis - comes in the form of the vigilante groups which have banded together to fight Boko Haram and protect civilians.

The most visible and most organized of these groups formed in Maiduguri in June 2013. The Civilian Joint Task Force (JTF), backed by the governor of Borno, has thousands of volunteers, 
mostly young men in their late teens and early twenties. Armed with machetes, a smattering of guns, and homemade weapons, JTF members man roadblocks and checkpoints in and around Maiduguri, stopping vehicles and searching them for guns and explosives. They solicit reports of Boko Haram activities and track down and apprehend suspected Boko Haram members in Maiduguri and as far afield as Abuja. While they often heed the instructions of JTF commanders and turn the suspects over to the police for detainment and questioning, the vigilantes have been known to take on the roles of judge and jury on their own, as well as that of executioner (Preston 2014; Okeowo 2014). Overall however, the Civilian JTF and other vigilante groups seem to be performing a necessary service the state has been unable to provide.

What remains to be seen is whether they can be kept in check, kept from becoming hired thugs for local politicians or from becoming yet another threat to the security and stability of the region. Equally as important, it remains to be seen what employment or educational opportunities can be presented to them should the crisis be brought to an end and their services no longer necessary. As Kashim Shettima, the governor of Borno and a vocal supporter of the Civilian JTF, said in a 2014 interview, "It is a wonderful thing to see: young boys with sticks chasing Boko Haram members armed with AK-47s," but in the end, "after this euphoria is over ... if we don't [create jobs for JTF members], we will have created a Frankenstein's monster" (Preston 2014). Having the governor of Borno act in support of civilians standing in opposition to Boko Haram is an encouraging step. Unfortunately, in years past a number of politicians and elites have done the opposite.

While the ranks of Boko Haram's foot soldiers have been filled with almajiri, the group has counted a number of northern elites, politicians, and academics as members and, more importantly, as financial supporters. Much of Boko Haram's operational funding (as well as their matériel) likely comes from criminal activities including more than a dozen bank robberies between 2011 and 2013, from looting police stations and armories, and from kidnapping and holding hostages for ransom 
(Campbell 2013, 138; Umar 2012, 127; Zenn 2012, 5). It has also been collected through "taxes" from civilians in more rural areas, through strong networks of paternalism that allow elite patrons to call upon their clients for financial donations, and possibly through daily membership dues (Onuoha 2012, 161). (In this instance it is unclear, however, how individual Boko Haram members gather their own funds with which to pay dues collected on a daily basis nor how leaders keep track of dues paid or not paid). Perhaps more importantly, the funding from those sources is heavily augmented by financial donations from wealthy elites who likely initially supported Muhammed Yusuf and his followers out of a shared ideology and may have continued to support the group after Yusuf's death because of the insurgency's ability to upset the power structures in place at the time (ibid; Campbell 2013; Umar 2012; Zenn 2012).

In contrast to current governor Shettima's vehemently anti-Boko Haram stance and vocal support of the Civilian JTF, his predecessor Ali Modu Sheriff has had to continually deny allegations that he provided funding to Boko Haram. The religious affairs commissioner under Sheriff, Buji Foi, was a known disciple of Mohammed Yusuf and was well known as the group's primary financier prior to Yusuf's extrajudicial execution at the hands of police following the events of July 2009. The funds supplied by Foi allowed Yusuf to establish microcredit schemes for his followers, the profits from which were subsequently used to amass arms and ammunition (ICG 2014, 12).

Former Chief of Army Staff Azubuike Iherijirika has been linked with Sheriff and accusations of supporting Boko Haram as well, primarily by Stephen Davis, an Australian who worked with the Nigerian government in attempts to negotiate with Boko Haram for the release of the Chibok schoolgirls (Tukur 2014). While Davis has maintained the veracity of his accusations towards Iherijirika, his evidence for the accusation was not entirely clear and an investigation by the State Security Service found no evidence that Iherijirika had financed or sympathized with Boko Haram or Muhammed Yusuf (Odunsi 2014). The allegations leveled against Iherijirika, whether the 
truth lies with Davis's accusations or the lack of evidence for them found by the security services, demonstrate how accusations of collusion with Boko Haram could easily be wielded by one member of the elite to tarnish a reputation or undermine a sense of authority of another.

It is possible that the elites and government or military officials provide financial support for Boko Haram because they share an ideological vision with the leaders of Boko Haram or because they believe in the group's stated goals and objectives. What is equally likely, however, is that the shadow Boko Haram casts across northern Nigeria — the instability, the insecurity, the rapidly diminishing collective faith in the federal government and its military and police forces - can be particularly useful even to those who do not necessarily agree with the ideology or have personal experience with the grievances behind the campaign. The potential usefulness of Boko Haram to certain members of the elite is detailed in greater depth in the following chapter, but what remains important here is that accusations of providing support for Boko Haram can be an effective tool for those who would seek to disrupt the authority of others. Similarly, despite the fact that Boko Haram regularly issues videos and statements claiming responsibility for its attacks, there has been consistent misattribution to the group of events for which it may not be responsible. This misattribution may be intentional as often as it is done out of misunderstanding or confusion.

To many the name Boko Haram "appeared to cover political opportunists and criminals as well as radical Islamists," and the name itself may in fact have been first adopted by the government and the media, who "applied it to virtually all antigovernment activity in the North, thereby imposing undue coherence on a diffuse, often localized revolt" (Campbell 2013, 129-131). The intentionality of these misattributions may go even further as "Nigerian authorities try to blame everything from global warming and HIV/AIDS to bank robberies, kidnappings and squabbles between neighbors, to post-election violence on Boko Haram — anything to deflect scrutiny from their own malfeasance, culpability and venality" (Hansen and Musa 2013, 290). This may sound hyperbolic but 
there is ample evidence that the shadow of Boko Haram has been used as cover for a wide variety of criminal activity, including politicians sanctioning the murder of their rivals ostensibly because those rivals were connected to Boko Haram, regardless of the existence of any hard evidence (Campbell 2013, 136). This intentional misattribution, along with the military's continual difficulties eliminating or even moderating the violence perpetrated by Boko Haram, suggests that for many of those in power or seeking to gain power — politicians who stand to gain from a lack of popular trust in the governmental leaders or from the inability of those leaders to effectively combat Boko Haram, for example - Boko Haram is as useful as it is dangerous.

A final source of support for Boko Haram may come from connections to various other insurgent groups across Africa and the Middle East, although it is difficult to verify how far this support actually extends beyond the verbal support exchanged by Boko Haram leaders and the leaders of other insurgent groups. In 2003, when Osama bin Laden singled out Nigerian Muslims, exhorting them to "incite and mobilize the Islamic nation ... to break free from the slavery of those regimes who are slaves of America," the call was ignored the vast majority of Nigeria's Muslim population (Campbell 2013, 55). Before his death, Mohammed Yusuf was arrested and charged a number of times with receiving undisclosed sums of money from al-Qaeda, although he was subsequently released each time (Onuoha 2012, 161). International connections appear to have grown stronger since the mantle of leadership passed to Abubakar Shekau, who has been known to move across the borders between Nigeria, Chad, and Niger with some regularity.

There is evidence of growing connections between Boko Haram and various other groups associated with al-Qaeda. This includes al-Shabaab, which has been active in Somalia, Kenya, and Uganda, and al-Qaeda in the Islamic Maghreb (AQIM), operating largely in Mali, Chad, Niger, and Algeria (Aghedo and Osumah 2013; Campbell 2013; ICG 2014; Onuoha 2012; Zenn 2012). The increase in suicide bombing attacks carried out by Boko Haram since 2009 may be a reflection of al- 
Qaeda's growing tactical influence, and leaders of Boko Haram, al-Shabaab, and AQIM have expressed deepening support for and desire to collaborate with each other in recent years.

After a June, 2011 suicide bombing attack on the police headquarters in Abuja, Boko Haram released a statement claiming that, "Our jihadists have arrived in Nigeria from Somalia where they received real training on warfare from our brethren who made that country ungovernable" (Pham 2012, 3). After the August 2011 attack on the UN office in Abuja, a statement was issued by Abdelmalek Droukdel, the leader of AQIM, in which he stated that his "group would provide Boko Haram with weapons, training, and other support in order to expand its own reach into Sub-Saharan Africa not only to gain 'strategic depth,' but also to defend Muslims in Nigeria and stop the advance of a minority of Crusaders" (ibid). Additionally, Shekau has released videos in which he verbally attacks and links together US President Barack Obama and Nigerian President Goodluck Jonathan, a transnational departure from the group's previously domestic focus and further indication of a potential strengthening of international connections (Campbell 2013, 140).

Again, however, it is unclear whether these are concrete connections or simple lip-service based in a desire by each group to conflate their own standing in the eyes of the rest of the world by combining their collective strength. The connection between Boko Haram and the al-Qaeda affiliates was likely more "an alliance of convenience" in which each group benefited from "the propaganda value of association with each other's deadly exploits," while actual training or collaboration has probably only occurred in very limited instances (Nossiter and Kirkpatrick 2014). What is presently more concerning then is the way in which al-Qaeda has begun to distance itself from Boko Haram for largely the same reasons that al-Qaeda split with the Islamic State (variously also referred to as IS, ISIS, or ISIL): because Boko Haram's and the Islamic State's "reputation[s] for the mass murder of innocent civilians is strikingly inconsistent with a current push by al-Qaeda's leaders to avoid 
such deaths for fear of alienating potential supporters" (ibid). It is little wonder then that Abubakar Shekau declared Boko Haram’s support for the Islamic State in July 2014.

Boko Haram's movements to align itself under the Islamic State have produced much more visible and compelling evidence of cooperation than did their previous connections to any of the African al-Qaeda affiliates. As such, the connection between Boko Haram and the Islamic State is more troubling than any of its previous attempts at international partnerships and is a far stronger indication of the importance of broader international forces - in this case, the development of technologies that facilitate transnational connections and relationships - to the development and longevity of Boko Haram's insurgency. Almukhtar (2015) provides a detailed timeline of the developing relationship between Boko Haram and the Islamic State which demonstrates that evidence of the partnership is found primarily in the development of Boko Haram's propaganda and social media presence. Since late 2014 the production quality of its propaganda videos has increased dramatically with special effects and French and English translations, suggesting that Islamic State media producers were providing substantial technical assistance. Boko Haram has since also created its own media outlet and delved into social media via its first Twitter account, allowing for a more regular release of content, much of which has subsequently been reposted by various other Twitter accounts known to belong to members of the Islamic State. On these various social media platforms Boko Haram, which had up to this point still officially been calling itself Jama'atu Ablissunnah lidda'awati wal Jihad, began to be referred to on Islamic State-linked social media accounts as ISWAP — the Islamic State's West African Province (Oladipo 2015).

Indeed, during this initial period that appears as to have been a sort of ramping up of relations between the two groups, "United States officials confirmed that the Islamic State was likely to have sent representatives to Nigeria [in February 2015] to negotiate its relationship with Boko Haram" (Almukhtar 2015). In a recorded statement released the following month, Abubakar Shekau 
reiterated Boko Haram's allegiance with a message that seemed to use the same script as other groups that had been accepted into the Islamic State. Within a week, Shekau's declaration was formally accepted by Abu Bakr al-Baghdadi, the Islamic State's caliph, and “other ISIS affiliates released celebratory videos to welcome the 'Nigerian mujahedeen”” (ibid).

In more recent developments noted in the previous section however, it would seem that Boko Haram's, or at least Abubakar Shekau's, relationship with the Islamic State may be short-lived. What this means for Nigeria, the people of the northern region, and Boko Haram itself remains to be seen, but there is a possibility for a realignment with al-Qaeda. Among Boko Haram's leaders who disagreed with Shekau's push to align the group with the Islamic State, there was a sense that "had it remained a part of al-Qaeda, which has a far stronger African network, Boko Haram would almost certainly be a more potent organization today" (Gartenstein-Ross and Zenn 2016).

Based on access to financial and military resources alone, this seems like it may in fact be the case. With the Islamic State's established presence in Libya, it seems the intention was to be able to supply Boko Haram with munitions and weaponry, but there do not appear to have been any such transactions or large movements of arms from Libya into Nigeria (ibid). Whether the Islamic State's Libyan factions are unable or unwilling to share resources with Boko Haram, if it continues it could further push Boko Haram back towards an affiliation with al-Qaeda. Because it has affiliates "waging an increasingly powerful insurgency in nearby Mali” (ibid), the thought process is the same as with the Islamic State in Libya - Boko Haram has to hope that proximity will prompt a redistribution of resources. Because as it stands now, Boko Haram's fighters are starving, stretched thinly across international borders and divided between factions, and its insurgency increasingly dependent on women and children with explosive devices. And yet it continues largely as it has for seven years. 


\section{5 - Tactics, Attacks, and Confrontations}

Fully chronicling every attack carried out by Boko Haram is important work and a necessary contribution to raising awareness of the crisis and giving validation to the more than twenty thousand people killed by Boko Haram and over two million displaced by its insurgency as of January 2017 (CFR 2017). While a full chronicle is too lengthy for this project, Appendix A provides a timeline of major attacks and developments in

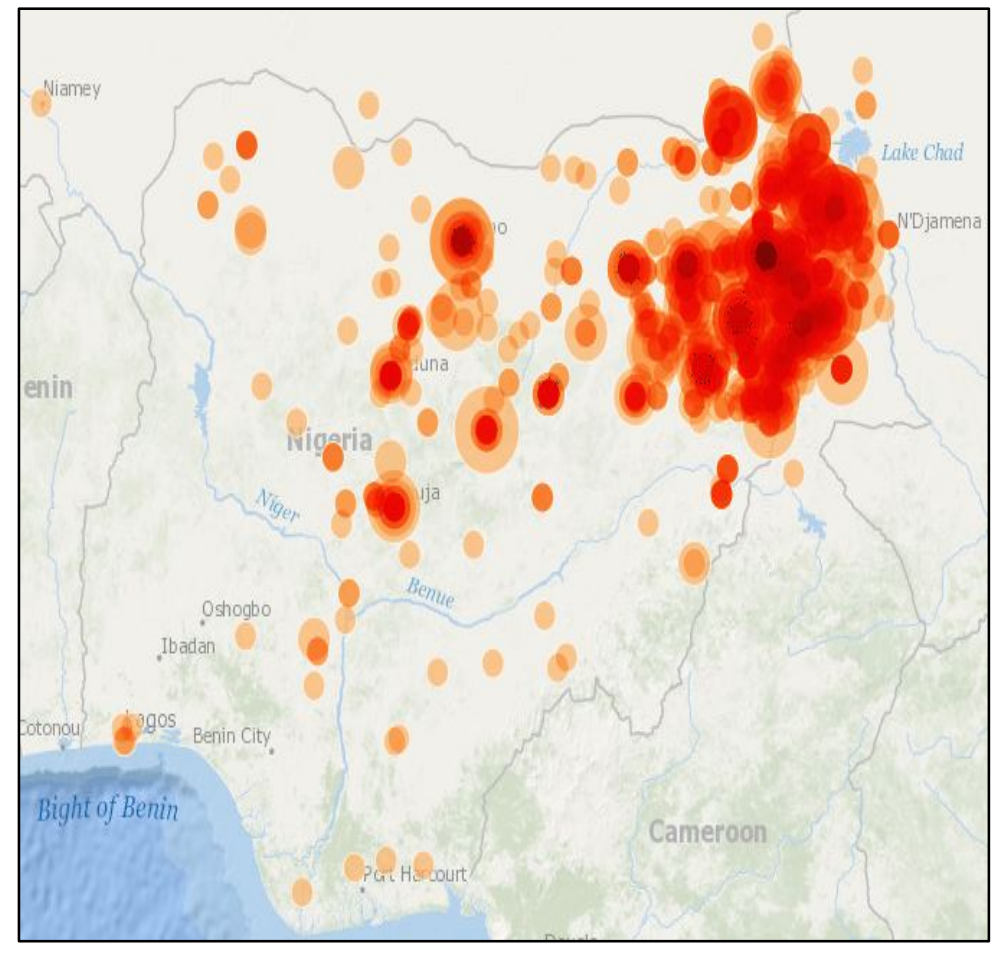

Figure 1: Boko Haram Attacks, 2009-2016 (Source: Ali 2017)

the insurgency. This section details, year by year, Boko Haram's major attacks, raids, and kidnappings through which the increasing sophistication and variety of its tactics can be seen. This also shows the changes in Boko Haram's geographical range: both the expansion of its reach and the corners it has seemingly been beaten into since Mohammed Yusuf's death. And included in the overview of each year are the major instances in which military and police forces attacked and killed civilians, intentionally or otherwise. The purpose of this section is to give weight to the assertions made about the devastation and chaos caused by the insurgency. It is not enough to look at theories and contexts. Boko Haram's actions must be understood as well.

As in the running gun battle that proceeded Yusuf's arrest and extrajudicial execution, Boko Haram's early insurgency was characterized by low-level guerrilla warfare and attacks on police stations, the targeted assassinations of community leaders and Islamic leaders deemed too moderate by 
Boko Haram leadership, drive-by shootings, and "poorly planned, open confrontation with state security forces" all of which were largely confined within Borno state (Onuoha 2012, 165; Brock 2011). The increasing sophistication and geographical range of its attacks became clear over the next two years, however.

The inauguration of Goodluck Jonathan in May 2010 was marked by a coordinated series of bombings in Abuja, Bauchi, and Maiduguri, killing sixteen people. Boko Haram subsequently claimed responsibility, and did so again a month later for an explosion at the police headquarters in Abuja which killed six people — including the man who detonated the bomb in his car, potentially making it the first suicide bombing in Nigerian history, the man described in the Boko Haram statement as "a martyr who sacrificed his life for the sake of Allah" (Brock 2011). Despite the blast and the death toll, however, it appears that the bombing was a failure in that it missed its intended target, Police Inspector-General Hafiz Ringim, who had vowed to defeat Boko Haram in a speech given in Maiduguri the day before the bombing (BBC 2011; Brock 2011). The next major attack was arguably Boko Haram's most successful up to that point and has remained one of its most highprofile: the bombing of the United Nations building in Abuja, a suicide attack which killed at least 21 and left over 70 wounded; the scale of the target and the death toll seemed to signal a shift in an insurgency that had suddenly become much more threatening (Nossiter 2011).

The following description of the development of the insurgency from 2011 onward draws from timelines produced by the Council on Foreign Relations' (CFR) regularly updated "Nigeria Security Tracker" (2017), Locke et al (2016), Stanford (2016), and Nigerian newspaper The Nation (2014), among others cited where appropriate.

The attack on the UN building raised concerns among the global community that Boko Haram was developing grander international ambitions and aligning itself more closely with al-Qaeda. The reality, however, turned out to be largely the opposite: rather than continuing to target large 
state and international institutions, the major offensives of the insurgency turned inward, directed at civilians, churches, and local police forces. By the end of 2011, the use of explosives had become a mainstay of Boko Haram attacks, and was increasingly complimented by mass shootings and raids by armed gunmen. Attacks on Christmas Day 2011 targeted churches in four cities across the northern and central regions, killing at least 41; this appears to essentially have inaugurated a campaign that would characterized the entirety of 2012, which saw at least six churches attacked with explosives and firearms over the course of the year, more than 790 casualties reported in Borno state alone, and an additional 200 people killed in a series of attacks in Kano.

While 2012 seems to have been a year of attacks on churches and their congregations, in 2013, Boko Haram appears to have dropped any pretense of having a specific enemy, expanding the scope of its violence to utterly indiscriminate levels. The expansion of the scope of Boko Haram targets to include mosques and Muslims demonstrates the development of the aspects of their ideology which saw "erring" Muslims as betrayers of the community, and is an indication of the threat that these other Muslims and their ostensible innovations - bid'a - posed to the authority of Shekau's ideology.

The year saw the first attacks directed at primary and secondary schools, colleges, students and their teachers. A mosque in Maiduguri was the scene of 56 deaths claimed by Boko Haram. Other targets included polio vaccinators in Kano, bus parks and markets, entire villages. A single attack on the town of Benisheik in Borno left 161 dead, while another in Damaturu, the capital of Yobe, resulted in 128 deaths. Despite all of this, Boko Haram may not have carried out the most devastating attack of 2013 at all, according to a 2013 report by Nigeria's National Human Rights Commission. Over 200 civilians died in a massacre in the village of Baga on the shores of Lake Chad. Hundreds more were wounded. Over 2,200 homes and businesses were destroyed in fires and five city wards completely razed to the ground. 
This loss of lives and livelihoods aside, the Baga massacre is important because police and military forces were the primary instigators, not Boko Haram, and were responsible for most of the atrocities committed that day. To highlight this as another instance of state failure exacerbating the crisis is an understatement. Police and military forces raided the village, firing indiscriminately, dousing buildings in gasoline and gunning down people as they fled the flames. That state forces killed people as they fled explains why a majority of the casualties were children or the elderly, unable to quickly escape. With entire villages being targeted by Boko Haram and by the police and military forces sent to combat them, 2013 became the deadliest year of the insurgency to that point.

Even compared to the previous year, the scale of the attacks carried out in 2014 reached unprecedented levels. Over the course of the year, Boko Haram claimed responsibility for seven attacks that claimed between 50 and 100 lives. Eight other attacks each resulted in over one hundred civilian deaths, including more than 300 killed on May 5 in the town of Gamboru Ngala near the Cameroonian border and an estimated 400 to 500 killed between June 3 and 4 in Gwoza District, Borno. For the year, the CFR's Nigeria Security Tracker lists over 4,600 people killed by Boko Haram and an additional 6,238 killed in clashes between Boko Haram and state forces - a death toll combining militants, state actors, and civilians. The violence and death was compounded by a significant increase in the number of kidnappings.

Over 300 girls aged sixteen to eighteen were kidnapped from their secondary school late on the night of April 14-15, an incident that gained widespread international coverage. While a number of the girls were able to escape or were rescued, in November 2014 Abubakar Shekau issued a statement saying that the girls had been converted to Islam and given as wives to Boko Haram soldiers. By the end of 2016, a reported 197 girls from Chibok remained in captivity, although Boko Haram has apparently indicated a willingness to negotiate the release of 83 (Sesay and Busari, 2016). While the Chibok kidnappings gained the most notoriety, 91 women and children were kidnapped in 
June, and in July the wife of Cameroon's Deputy Prime Minister was kidnapped by Boko Haram soldiers in an attack in northern Cameroon. While she and 27 others kidnapped by the group were released in October, another 185 were taken two months later. Once again, however, Boko Haram was not the sole perpetrator of violence. According to Amnesty International, on March 14, after Boko Haram members attacked the Giwa military barracks and freed a number of their comrades, the military recaptured and executed over 600 unarmed detainees (Amnesty International 2016).

In 2015 , the crisis continued, though not entirely unabated. Over 4,400 people were killed by Boko Haram, an additional 3,970 died in clashes between Boko Haram and state forces. January saw the worst single attack in the entire insurgency. In a four-day assault, the town of Baga — where military and police forces massacred civilians in 2013 - and sixteen surrounding villages fell under siege. In the end, there were an estimated 2,000 dead and between 10,000 and 35,000 displaced from their homes. There was a measure of hope in the following two months, however, as the West Africa Allied Forces made significant territorial gains. Made up of soldiers from Nigeria, Chad, Cameroon, and Niger, the combined forces retook large swathes of territory that included the sites of earlier massacres such as Baga, Gwoza, and Gamboru Ngala. During an offensive into Sambisa Forest, 450 kidnapped women and girls were rescued. These victories were followed by optimistic reports of Boko Haram's imminent decline (Corones 2015). But those reports would prove to be premature.

July began with raids on three villages in Borno that left 145 dead, and was punctuated by deadly explosions in a number of mosques in Borno, in a church in Yobe, and two more in the central city of Jos. The year also saw Boko Haram carry out its first attack in the Chadian capital of N'Djamena, along with the increasing use of women and girls as suicide bombers, and the declaration of allegiance to the Islamic State. Presidential elections in April were largely peaceful, and with his victory, Muhammadu Buhari vowed to end the insurgency and "appealed to Western partners to step up assistance to his country and visited Cameroon, Chad and Niger to strengthen cooperation 
for a regional fight" (Locke et al, 2016). Not long after he took office, however, 150 people died either drowning in a river or being shot as they fled Boko Haram soldiers during an attack in Yobe, and the year ended with at least six suicide bombings between August and December. At the end of the year, Boko Haram had gained a new level of infamy by becoming the deadliest terrorist organization in the world (Allen 2016).

While the insurgency continued throughout 2016, the Nigerian military was finally able to make a number of advances against Boko Haram at the end of the year. Prior to that, however, the year opened with a particularly horrific attack on January 30 in the village of Dalori, four kilometers outside of Maiduguri. At least 86 people were killed and dozens more injured in an attack that lasted more than four hours and by some estimates involved over 100 Boko Haram soldiers who opened fire on civilians and burned children alive while suicide bombers targeted crowds of people (Al Jazeera 2016b; Economist 2016). On February 9, two female suicide bombers disguised as disabled victims of the insurgency detonated explosives in a camp for displaced persons in Kano, killing 58 and wounding nearly 80 more. The number of casualties could have been even higher, however, but a third bomber allegedly realized that her family had fled to the camp as well and refused to set off her explosives (Abubakar, Melvin, and Busari 2016). By April, it was estimated that at least 105 women and girls had carried out suicide attacks for Boko Haram since June 2014 (Searcey 2016a).

The use of women and girls as suicide bombers raises important questions regarding how they come to agree to carry out attacks. Some women who have escaped Boko Haram describe how, after they were kidnapped by Boko Haram soldiers, women were put through several months of daily education and training courses that included Islamic teachings and instructions on how to build and detonate explosives. Promises of eternal life are often supplemented with food deprivation. Over the course of the training, some of the women come to accept Boko Haram's ideology and the goals of the insurgency, becoming enthusiastic about carrying out attacks. Others, however, have 
suspected that Boko Haram drugs the women's food in order to make them more agreeable to instruction, or that the explosives they carry are sometimes detonated remotely (ibid). The gender component of the insurgency requires more space than is allowed in this project in order to be fully understood, but the reality is that just as with the men in Boko Haram, the women take part in attacks for a number of different reasons, many unwillingly but some with enthusiasm.

Boko Haram continued its attacks on civilians in villages and camps throughout 2016, while also stepping up the number of attacks on soldiers in convoys and military outposts, with dozens of military personnel killed in each of a number of attacks, indicative of the split between Shekau's faction and its civilian targets, and al-Barnawi's faction focusing attacks on state forces and military installations. Compounding the physical toll and loss of life directly caused by Boko Haram is a food shortage developing as farmers have been forced to flee their fields and villages, trade has declined rapidly, and markets ceased operating (Searcey 2016b). By the end of the year, at least 1.8 million people in the region were at risk of starvation and in November, representatives from the humanitarian group Doctors Without Borders stated that up to $50 \%$ of children under five in Borno are acutely malnourished (Liu and Roberts 2016).

In the latest and possibly most disturbing development of Boko Haram's tactics, on November 28, a woman approached a Civilian JTF checkpoint in Maiduguri with an infant on her back. While many of the details seem unclear, the JTF members shot the woman, detonating the explosive she had been carrying (Abdulrahim and Faul 2016; Obaji 2017). While Boko Haram had already established a pattern of using women and children as suicide bombers, it appears this was the first instance in which a bomber attempted to deflect attention away from herself and her explosive device by cloaking herself in the guise of motherhood. The suicide bombing attacks continued as the year ended, including one in the town of Madagali on December 9 in which two bombers, both reported- 
ly school-aged girls, killed nearly 60 people in a marketplace. In the end however, despite all of this, 2016 saw fewer people killed by Boko Haram than in any year since 2012 (Allen 2016).

The decline in casualties can be partially explained by the food crisis, as a number of recently captured Boko Haram soldiers have been gaunt and on the verge of starvation. The release of 21 of the Chibok schoolgirls in October further indicates that Boko Haram is struggling to feed its soldiers, let alone the kidnapping victims being held hostage. The food shortage is likely also at least partially responsible for pushing Boko Haram deeper into Cameroon as its soldiers hunt for some way to feed themselves (Searcey 2016b). An additional factor is the split, mentioned in the previous section, between the faction of Boko Haram still referring to itself as JAS and led by Abubakar Shekau and the faction that remains aligned with the Islamic State and led by Abu Musab alBarnawi, the son of Muhammed Yusuf. Not only was each faction left each with fewer soldiers and supplies than before, but there have been reports of in-fighting between the groups that has further weakened the insurgency (Withnall 2016).

While Shekau and his followers continue to primarily focus their attacks on civilians, alBarnawi's faction has reportedly "pledged to focus on Western and strategic military targets," (Searcey and Schmitt 2016) as evidenced by the increase in attacks on military personnel. The fracturing of the group, the difference in target populations between Shekau's and al-Barnawi's soldiers, and the ongoing food shortage may be stretching both factions too thinly across state and international borders to be as effective as their combined efforts had been in previous years. The continued vigilance of the Civilian JTF has been crucial to slowing Boko Haram in recent months along with improved counterinsurgency efforts by a multinational force of soldiers from Nigeria, Niger, Chad, and Cameroon.

The Nigerian military's offer of amnesty to Boko Haram soldiers who agree to take part in a deradicalization program appears to have enticed a number of soldiers to leave the group and turn 
themselves in. And yet, as with almost every aspect of this crisis, the reality is not so simple and the state is failing in its execution yet again. While the military is offering amnesty to those soldiers who turn themselves in and undergo the deradicalization program, many more people who were kidnapped by Boko Haram and escaped or were released are being detained indefinitely in military barracks, including women, children, and babies. Over 150 people died in Giwa barracks, being used as a detention center, in 2016 and Cameroon has reportedly also had suspected Boko Haram supporters die in custody while awaiting any sort of trial or investigation (Searcey 2016c). Even a number of the 21 girls from Chibok who were released by Boko Haram in October were detained by military forces and it was not until Borno governor Kashim Shettima intervened that they were allowed to return to their families (Sesay and Busari 2016). In spite of these mistakes, the multinational forces made significant progress to end the year — if President Buhari is to be believed.

In a statement released on December 24, Buhari declared that Boko Haram was "on the run," as military forces had succeeded in "crushing the remnants of the Boko Haram insurgents at 'Camp Zero,' which is located deep within the heart of Sambisa Forest”' (BBC 2016). The statement likely inspired little confidence, however, as it was released exactly a year after Buhari claimed that Boko Haram was “technically defeated” (BBC 2015). And just a few days after Buhari's most recent statement, Abubakar Shekau released one of his own in which he chastised Buhari for lying to the Nigerian people, claimed that the war was not over, and swore that there would be no respite from Boko Haram's attacks (VOA 2016).

On January 17, a Nigerian fighter jet mistakenly attacked a refugee camp near the borders of Chad and Cameroon, dropping multiple bombs and killing at least 236 people who had fled Boko Haram. Buhari called the attack a "regrettable operational mistake" that occurred during Air Force attempts to "mop up" Boko Haram soldiers (Searcey, 2017), an indication that he is standing by his earlier assertion that Boko Haram members are on the run and the insurgency in its last days. Just 
two days after the bombing by the Air Force however, an estimated 100 Boko Haram soldiers launched their own attack on the camp likely because of the opportunity afforded by the lingering chaos of the bombings, though as of this writing the army has refused to release a complete count of the number killed (Lanre 2017).

The end of the rainy season — during which dirt roads often become impassable — has allowed Boko Haram to increase its attacks toward the end of December and through January. The first month of 2017 ended with a spate of suicide bombings. Three girls detonated explosives near a checkpoint in Madagali, two outside of it, the third just inside, having been allowed to pass because of the infant she carried on her back in what could be an indication of an alarming new pattern (Obaji 2017). Another attack — carried out in part by a seven-year-old boy — killed two during morning prayers in the mosque at the University of Maiduguri. And on a single day less than a week later, three more attacks took place elsewhere in the city (AP 2017). At the beginning of 2017, it would seem that Shekau, not Buhari, was telling the truth in his most recent statement. Boko Haram was not crushed; the war would continue.

\section{$3.6-$ Conclusion}

Based on the last half of 2016 through the first month of 2017, it's fully clear that Boko Haram as a group is undergoing dramatic changes, which are reflected in its members, supporters, and tactics. There are certain encouraging aspects that indicate that Boko Haram's grasp on the region is growing increasingly tenuous. The physical health of some of the soldiers captured by, or turning themselves in to, the military indicate that the food crisis is taking an equally heavy toll on the insurgents as on civilians. The full effects of the in-fighting and fracturing into JAS and ISWAP remain to be seen, but it could result in two weaker groups, possibly increasing the chances of defeat for one or both at the hands of the multinational combined forces. 
The fracturing could reduce the number of civilian casualties at the very least, as al-Barnawi's followers focus on Western and military targets. The popular support Boko Haram once enjoyed in Borno has fully dissipated because of the delegitimation of the group resulting from its attacks on civilians, and has been replaced by vigilante groups willing to fight back. And the stark increase in suicide bombings carried out by women and children could indicate that Shekau's faction of Boko Haram is running out of soldiers, arms, will, or a combination of the three.

At the same time however, each of these instances in which there can be found some form of encouragement if one seeks it out, is also an indicator either that the crisis will not end even if Boko Haram itself does or that, ironically, Boko Haram in a weakened and fractured state could be more difficult to defeat than ever. Military forces will likely have to split time and effort fighting two separate insurgent groups, which could increase the likelihood that the broader insurgency as a whole will carry on much longer than otherwise. That the crisis will not end even if Boko Haram both of the main factions — is wiped out is proven by the 1.8 million people on the brink of starvation, the half a million displaced from the homes, and the ongoing economic damage as a result. There is the concern that members of vigilante groups will be difficult to control if they have no enemy left to fight and no jobs to return to. And the consequences of the increasing use of suicide bombings, particularly by women and children, could increase deaths of innocent civilians at the hands of military, police, and vigilante forces as it becomes more and more difficult to tell who may be an insurgent attacker. It could also prolong the insurgency as Boko Haram could continue carrying out isolated bombings until every captive woman or child has been sent out on an attack or rescued by military forces. Or both instances could happen.

At present, only two things seem certain. The end of Boko Haram, if it comes, will come slowly; the insurgency will drag on, carried out by one faction or the other. And that the effects of the crisis will reverberate for years to come. Fundamental changes have occurred in recent months, 
and could likely be signaling a shift in the trajectory of the insurgency. What has not changed, however, neither recently nor for years, are the socioeconomic and political conditions that facilitated Boko Haram's establishment in northern Nigeria in the first place. The next chapter will lay out these conditions, along with others including religion, ideology and the political geography of the region, to complete the understanding of this crisis. 


\section{Chapter 4}

State failure and the geographic, political, socioeconomic, and transnational factors involved in the insurgency

While the historical religious precedents established by the introduction of Islam into the region, the Jihad of Usman Dan Fodio, and the patterns and expressions of dissent and discourse among Muslims in northern Nigeria provide a partial answer to the question of why Boko Haram came to establish itself in the region, it is equally important to understand the more recent historical and current socioeconomic and political contexts. These contexts further flesh out the answer to the central questions of this chapter: why here, and why now? In short, it is not only that Boko Haram came into being in a heavily Muslim region with a rich history of both Islamic authority and dissent against that authority. The existence of that history, along with the importance of religion and religious identity, gives guidance to understanding the ideology behind the insurgency. But it is the political and socioeconomic conditions created within the last century, and particularly since Nigeria gained its independence in 1960, that have not only motivated Boko Haram to carry out its campaign against the state and the people of the region, but that have also created the ideological and physical space that have allowed for its success.

Each of the four sections of this chapter analyze a distinct factor that has played a large role in allowing Boko Haram to come into existence where and when it did. The first section returns to the colonial period briefly touched on previously, specifically examining how the differing approaches taken by the colonial authorities towards the northern and southern halves of the colony continue to have socioeconomic effects that reverberate through the present day. This section also includes a discussion of the political geography that has assisted the rise of Boko Haram. This includes the prevalence of rural-to-urban migration, as well as the socioeconomic disparities that exist between rural and urban areas of the northern region, between the northern and southern regions as a whole, and as a result, between Christians and Muslims. 
Section two examines the effects of the relationship between religion, politics, and power that has developed since Nigeria's independence. Section three extends this discussion into a broader examination of the failures of the Nigerian state, including an inability to provide basic services to all of its citizens and an inability to make sustained progress against Boko Haram or to do so without the loss of civilian lives as collateral damage. The state's failures are seen not only in the loss of civilian lives, homes, and civilians but also in promoting a willingness or desire to rebel against an ineffective political structure without the level of education that would be necessary to enact peaceful change or a nonviolent and politically-motivated transition of power.

The failures of religious leaders — likely more egregious to the leaders and members of Boko Haram than those of the state — that Boko Haram sees as corrupt or un-Islamic or backsliding, are also important as they have created a void into which Boko Haram has been able to insert itself and its ideology. As Boko Haram has filled that void, it has done so with the assistance physical, financial, or simply ideological — of similarly-minded groups. While this has been discussed in part already, this section extends that examination into one of the globality of Islam or Islamism and the importance of the idea of religious community to Boko Haram's ideological underpinnings. Furthermore, the presence of and connection to other ideologically-similar groups may have hardened Boko Haram's resolve, its member's sense of righteousness and rightness, energizing the insurgency and motivating the soldiers to continuously take the fight to the state and its civilians.

The globality of Islamism and the increasingly transnational scope of the crisis - through attacks into Niger, Chad, and Cameroon and, perhaps more importantly, through the developing food crisis that has spread across the region — are not the only ways that the development of Boko Haram and the trajectory of its insurgency have been affected by global political and economic forces having little to do with northern Nigeria on the surface. Section four provides a discussion of globalization and its effects on Boko Haram. In doing so, Nigeria's oil economy provides a thorough 
example of one way in which the insurgency has been affected by powerful global forces seemingly beyond the scope of the crisis. It is critical to ensure that the full understanding of Boko Haram that is the aim of this project is situated within the increasing globalization that has defined the world over the last two decades through technological advances that have facilitated the speed at which ideas, capital, and even people can move. The insurgency of Boko Haram is a product of its regional history and its religious foundations, but it is also a product of the world as a whole.

\section{1 - The continuing effects of the colonial policy of indirect rule}

The vestiges of the Sokoto caliphate provided the British with a preexisting structure of governance through which to rule the northern half of the colony, in exchange for allowing the continued institutionalization and rationalization of Islamic law in the region. The southern region, on the other hand, lacked similarly strong overarching structures that had been in effect prior to colonization. Previous incursions of Anglican and Roman Catholic missionaries into the southern region, however, meant that much of the southern population and many of its leaders were generally more open to Western thought and influence than their northern counterparts. As a result, the colonial administration established its own strongly centralized institutions and systems of governance through which they could rule as they did through the remains of the caliphate in the north (Campbell 2013, 2). As these institutions were being established, European missionaries were setting up schools that would provide Western-style education to the local population.

There was a caveat to gaining access to this education, however, and enrollment in the missionary schools was available only to those who would convert to Christianity. Newly converted and newly educated Christians were then able to "acquire occupational skills [that allowed them] to dominate the public service" for years to come (Onapajo 2012, 50). Their presence in the public service sector was parlayed into a relationship in which Western nations would provide extensive monetary 
support to southern, Christian institutions, furthering their domination of the educational and economic sectors. Thus was the system of indirect rule implemented in the south. Though the structures of governance were conceived of and implemented almost entirely by the colonial administration, they were run largely by local leaders from the area, new Christians converted and educated by European missionaries (Hill 2012, 47).

In effect, the colonial administration had created a northern Muslim state that continued to exist under the auspices of Islamic law much as it had before the conquest of the Sokoto Caliphate, and a southern Christian state ruled through British-style government institutions. The southern Christians used their Western educations to gain access to positions within the civil service sector that would ultimately become the foundation of the post-independence government. Meanwhile Muslim leaders in the north were encouraged to believe that if their people were allowed access to this Christian-sponsored schooling, they would mobilize against the Islamic authorities, ultimately unseating them from power in favor of secular forms of government. The indirect rule that allowed the emirate structure to retain its traditional authority and to rule the northern region in a manner largely separate from the established colonial government structures in the south precluded extensive commingling between Christians and Muslims.

This likely allowed for stronger and more orthodox forms of Islam to retain their influence in the region as compared to the more moderated forms that would become common in southern regions as a result of regular and consistent interactions between Muslims and Christians, often within the same family as people converted between the two major religions with little social consequence (Last 2012, 23-24). When Nigeria gained its independence in 1960, all of this was confined within a single border. Two major religions promoting two different education systems under the auspices of two different forms of centralized governance all forced to try to move forward as one. In this way, these historical factors that laid the foundation of possibility for Boko Haram's exist- 
ence in northern Nigeria also helped create or deepen the geographical factors that have facilitated the northern insurgency.

The British establishment of governing structures in the southern half of the colony as opposed to the continued existence and authority, moderated though it was, of the emirate structures in the north has had consequences that have lasted until the present day, affecting the geographic, demographic, and urbanization patterns of the country as a whole. All of this has a played a significant role in allowing for Boko Haram's foundation in the northeast. The ostensibly secular governing structures in the south meant that the colonial government, as well as the post-independent federal government, spent significantly more money to build up urban infrastructure in the southwestern region than elsewhere in the country. Additional funding came from Western governments and

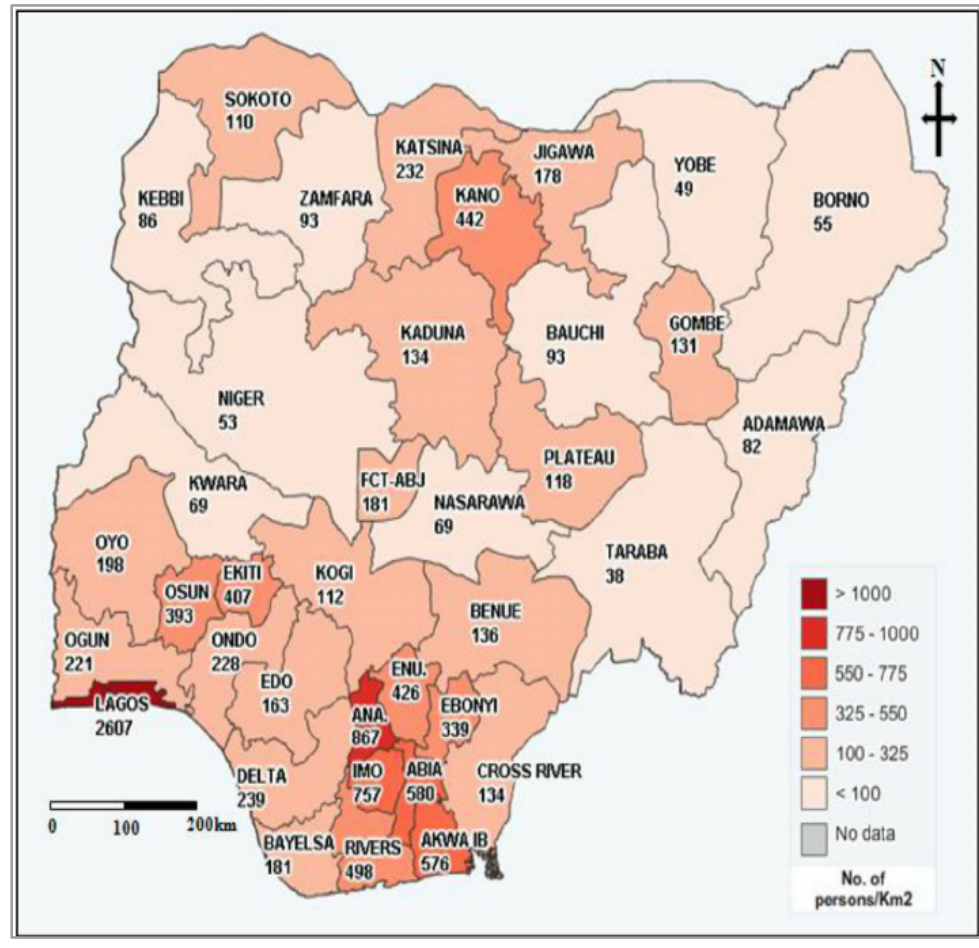

Figure 2: Population Density by State, 2013 (Source: Akpan 2015) organizations that partnered with

Christians in the south. As the southern cities were built up, the urban population increased accordingly in total size as well as density. Today the south-south and south-west geopolitical zones, along with the city of Lagos in the south-east zone, are the most highly urbanized and densely populated regions in Nigeria. Kano is the only northern state to match those in the south in terms of population density Yobe and Borno states, the birthplace and home of Boko Haram, have the lowest population densi- 
ty in the country outside of their singular urban centers. Based on the most recent data available, Figure 2 shows population densities by state for 2013 .

As in the specific case of its encampments in Sambisa Forest, these large swathes of rural and undeveloped areas allow Boko Haram the physical space to gather, set up encampments, train its foot soldiers, and hide its captives away from those urban centers. Indeed, Boko Haram has been able to prolong its existence by remaining outside of cities and towns - except when carrying out attacks — where police forces, military barracks, vigilante groups like the Civilian JTF, and ordinary civilians are willing to stand in opposition to Boko Haram's ideologies and tactics and physically oppose the insurgency as needed. Additionally, while the northern region does not have many major urban centers with the size and population density to match those in the south, there has been a similar trend of rural-to-urban migration. This was also to the advantage of Boko Haram at least in the early years of the insurgency, particularly in regards to the almajiri moving into Maiduguri.

In fact, the rural-to-urban migrations of the almajiri reflect recent trends in the prominent geographical locations of Islamic dissent. In recent years, the most decisive act of Muslim dissidence in northern Nigeria has seemingly ceased to be the removal of oneself and one's community from urban centers under the control of the state and under the auspices of mainstream Muslim leaders. Maitatsine established himself and his followers in Birin Kano around 1979, and Mohammed Yusuf did the same in Maiduguri years later, making them the first "radically Islamic groups" to reverse the historical pattern of urban-to-rural migration undertaken by dissidents in years past. "Part of their rationale was no doubt easier access to funds, but another part ... was to attract and keep still more adherents of a certain sort — the disengaged, excluded young in search of a cause” (Last 2012, 26). Indeed, modern rates of urbanization and rural-to-urban population shifts mean that "today the new site for dissent is primarily urban, not rural ... [and] in a sense, then, cities are where a vibrant religious culture is to be found - and the variety of practice includes different strands of dissent" 
(ibid). This new reality of urban centers as centers of dissent has facilitated the growth and success of the Boko Haram insurgency in three major ways.

The first, already mentioned, was the easier access to funds, whether through donations or looting and bank robberies, and the sponsorship of the group by local politicians and elites. The second is that increasing pool of potential recruits, the boys and young men migrating from areas where dogmatic, orthodox forms of Islam had been normalized over the years, often arriving in Maiduguri alone and susceptible to the guidance of their mallams and the new Islamic authority figures in their lives: the leaders of Boko Haram. The third, equally important to the ability of Boko Haram to have such devastating success in terms of territory gained and civilians killed or displaced, has arisen in recent years as the trend of rural-to-urban migration met with Boko Haram being forced out of Maiduguri and, in a sense, back once again into the historical migratory patterns of Muslim dissidents. The migration of boys and young men from rural villages to urban centers has ended up "leaving the countryside remarkably short of young men" (Last 2012, 29).

While women have physically turned back Boko Haram attacks in a number of instances in recent years, much of Boko Haram's potential opposition has left for the cities, leaving rural women and girls increasingly vulnerable to kidnapping, forced marriages, and rape. Urbanization, migratory patterns, and the decreasing density of the rural populations gave Boko Haram a distinct advantage as its insurgency developed. (It is worth repeating, however, that these factors have more recently seemed to be leading Boko Haram towards an eventual end as it stretches itself thinly across these rural areas, struggling for sustenance in the ongoing food crisis it helped create as it forced farmers from their fields, shuttered markets, and slowed trade in the region.) 
The divisions between northern and southern Nigeria, entrenched by the colonial authorities and continually being represented by differences in religious makeup and attitudes towards tolerance and dissent, are today manifested in socioeconomic disparities as well. While economic indicators show rising poverty levels across the country, increasing income inequality is equally devastating. The most blatant inequality is obviously

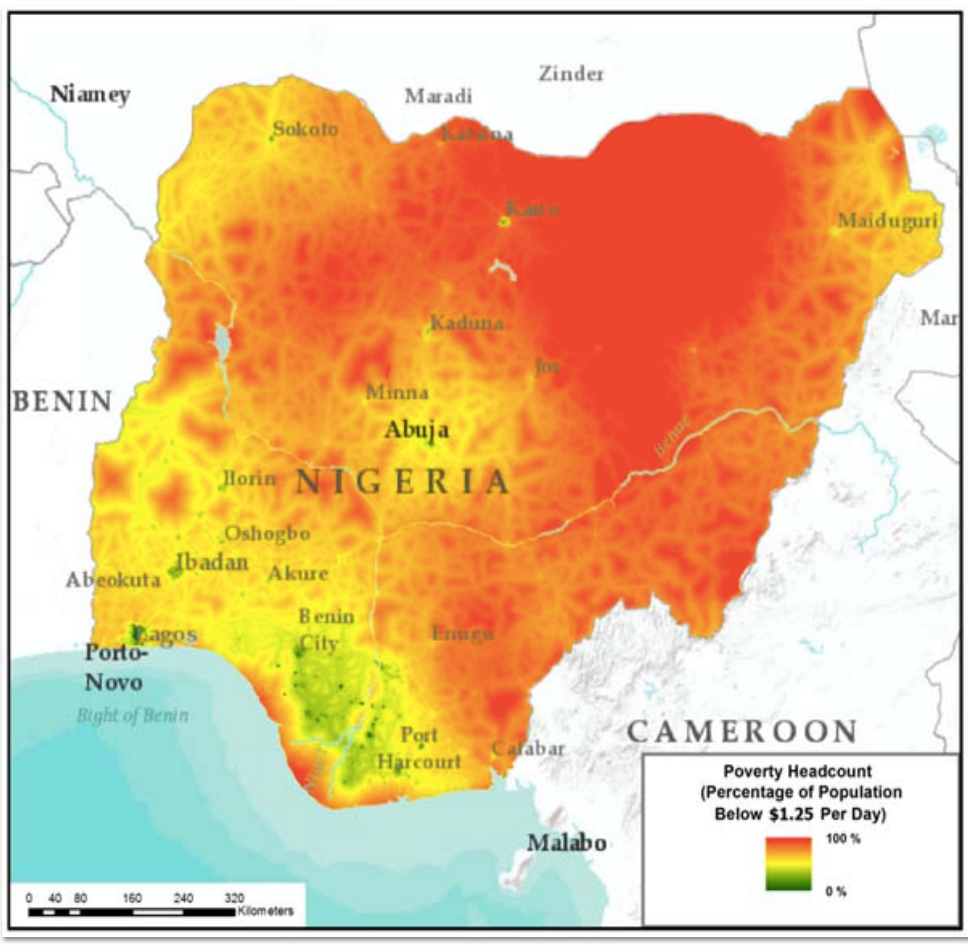

Figure 3: Population Living on less than \$1.25/day (\%) 2013 (Source: WorldPop 2013) between the general population and the wealthy elites of both the political and private sectors, but as seen in Figure 3, the depth of poverty in the north is much greater than in the south, and in particular in the northeastern states where Boko Haram has been most active.

This regional disparity is often perceived as a religious one as well, seen by many as being between Muslim and Christian. Deeply entrenched patronage networks extending throughout the country run along religious lines as often as ethnic ones and as a result the majority of the revenue produced by the oil industry in the Niger Delta stays in the South (Campbell 2013, 63). Likewise, “because of intense competition among Nigeria's 300 ethnic groups for access to state-controlled petroleum rents, the Islamic/Christian division often overlays sharp regional and ethnic divisions, thus sharpening the communal competition for the distribution rents generated by the export of petroleum and natural gas" (Lubeck, Lipschutz, and Weeks 2003, 5). Far from being only a northsouth disparity, however, there is also a distinct inequality between Nigeria's rural and urban popula- 
tions throughout the country (UNDP 2015). It is this reality that has prompted the movements of almajiri into Maiduguri and that has been fully taken advantage of by the leaders of Boko Haram.

Directly tied into these economic factors are human development indicators such as infant mortality, life expectancy, literacy and education levels especially among girls, and access to potable water among others. In these areas the effects of the colonial administration's warning of Muslim leaders against Western education and its banning of missionaries from establishing schools and hospitals continue to affect millions of Nigerians as the northern region continues to perform much worse than the south (Hill 2012, 23-24). And keeping in line with the marginalization of the north that began with the colonial era, the Nigerian government continues to be at fault for much of the northern region's performance on these indicators.

As of 2013, the south-south and south-west geopolitical zones commanded nearly half of all national spending on health, education, and public administration despite combining for roughly thirty-five percent of the national population. This leaves the north-west and north-east zones, home to roughly forty percent of Nigerians, with barely over a quarter of the national expenditures on

\begin{tabular}{|c|c|c|c|c|c|}
\hline \multicolumn{6}{|c|}{$\begin{array}{l}\text { Table 2: Human Development Indicators } \\
\text { (Source: UNDP 2015; NPC 2014) }\end{array}$} \\
\hline $\begin{array}{l}\text { Geopolitical } \\
\text { Zone }\end{array}$ & $\begin{array}{c}\text { Under-five } \\
\text { mortality } \\
\text { rate (per } \\
1,000 \text { live } \\
\text { births) }\end{array}$ & $\begin{array}{c}\text { Women } \\
\text { with access } \\
\text { to antenatal } \\
\text { care }(\%)\end{array}$ & $\begin{array}{c}\text { Population } \\
\text { with access } \\
\text { to drinking } \\
\text { water }(\%)\end{array}$ & $\begin{array}{l}\text { Children 12- } \\
23 \text { months } \\
\text { fully vac- } \\
\text { cinated }(\%)\end{array}$ & $\begin{array}{c}\text { Women } \\
\text { aged 15-19 } \\
\text { who are } \\
\text { mothers }(\%)\end{array}$ \\
\hline $\begin{array}{l}\text { North- } \\
\text { Central }\end{array}$ & 100 & 67 & 49.7 & 27 & 19 \\
\hline North-East & 160 & 49.3 & 37.9 & 14 & 32 \\
\hline North-West & 185 & 45.6 & 50.4 & 10 & 36 \\
\hline South-East & 131 & 95.8 & 71.4 & 52 & 8 \\
\hline South-South & 91 & 79.4 & 67.4 & 52 & 12 \\
\hline South-West & 90 & 94.3 & 69.6 & 41 & 8 \\
\hline
\end{tabular}

health, education, and public administration (UNDP 2015). As a result, the percentage of both boys and girls attending school in the north is much lower than in the south, a harsh reality that is compounded by the fact that, as shown in Table 2 , northern children under five years of age have a significantly higher mor- 
tality rate than their southern counterparts while pregnant women are much less likely to receive antenatal care if they live in the north than if they were to live in the south.

Furthermore, whether they are able to complete secondary school or not, a staggering unemployment rate - coupled with the fact that merely four percent of women in the north-east and north-west zones are in wage-earning positions outside of the agricultural sector — prevents many people, especially young people, from achieving any sort of economic self-improvement that could narrow the income inequality gaps. Each one of these facts points to a state and a federal government that, although it is failing the majority of its people across the country, is failing certain segments of society — northern more than southern, rural more than urban, Muslim more than Christian — to a much greater degree. And in a society like Nigeria's, where the segmentation runs deep and is regularly acknowledged, that can only lead to unrest.

While improving performance on all of these socioeconomic and human development indicators is critical, three have been particularly important to Boko Haram's existence in northern Nigeria: income inequality, unemployment, and education, all of which are highly interrelated. The levels of income inequality between rural and urban areas increases the number of boys and young men, almajiri or otherwise, being sent from the deep rural villages into urban centers like Maiduguri or

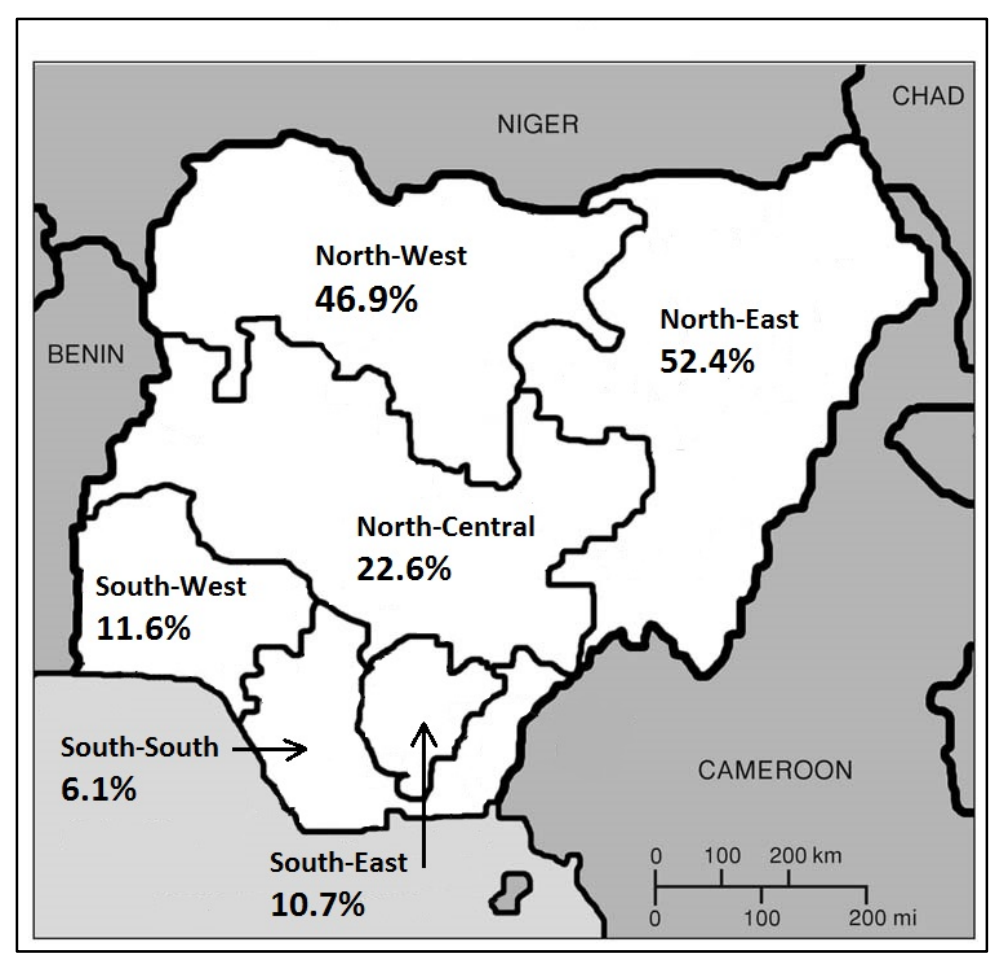

Figure 4: Males with No Formal Education by Geopolitical Zone (\%) (Source: Afri-Dev Info 2015) 
Kano in hopes, realistic or not, of finding a viable source of income in the cities.

However, as shown in Figure 4 and Figure 5, 52 percent of males in the north-east zone and 47 percent of males in the north-west zone have never received formal education. Education is even less common for females: 61 and 63 percent of women and girls in the north-east and north-west respectively have never received formal schooling. Among the northern Nigerians, both male and female, who have been fortunate enough to receive some formal education, less than half made it into secondary school. Expectedly, school attendance and literacy rates are much lower in rural areas than in urban. Rural populations are deeper in poverty to begin with, increasing the numbers of urban migrants. And because they are less likely to have formal education, the likelihood of gainful employment upon migrating to the urban areas is even more remote than it is on average. At the same time, even those who have finished secondary school or university face staggering levels of unemployment. Ultimately, this lack of opportunity feeds into frustration and disillusionment with the state and exacerbates feelings of marginalization. For some, the result is an increased susceptibility to the rhetoric of religious leaders, like the leaders of Boko Haram, who would recruit them to act against a state that has failed to provide them with education or employment opportunities or both. Once recruited into Boko Haram's ranks in order to fight state forces, these young men and women

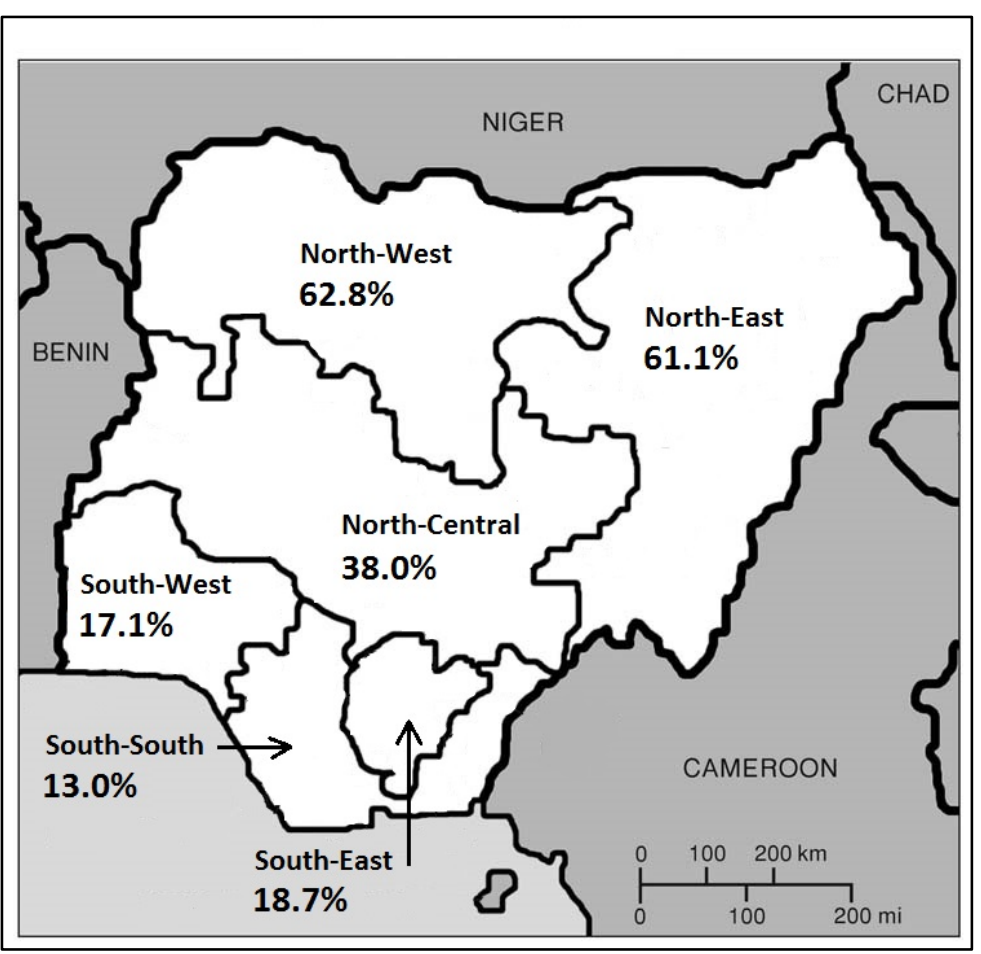

Figure 5: Females with No Formal Education by Geopolitical Zone (\%) (Source: Afri-Dev Info 2015) 
would have undergone the education and training courses described earlier in order to convince them to expand the targets of their attacks to include civilians and other Muslims as well.

Because of the high unemployment rate and low levels of schooling among young people, these socioeconomic factors have a generational component to them as well. In fact, "generational experiences are critical for understanding the discursive shift to Islamism" that has been taking place in northern Nigeria since the turn of the century (Lubeck, Lipschutz, and Weeks 2003, 5). Despite the fact that half of all northern men and almost two-thirds of all northern women have received no formal education, the younger generations, including those in their late teens or early twenties, are much better educated than their parents and grandparents. This has done comparatively little to improve their quality of life over that of previous generations, however, and now entering adulthood, they have "only experienced economic decline, institutional decay, authoritarianism, and rising poverty" (ibid). Most of them have never known a state that feels popularly legitimated in the way that Sharia has been described, nor have they been citizens of a nation that provides a sense of belonging and security like that which can be found in religion. Instead, they have known only a state characterized by "economic decline, ruthless authoritarian rulers, endemic corruption and widespread personal and social insecurity" (ibid, 17). It is little wonder, then, that young people are angry and disillusioned, seeking alternatives to the Nigerian state, and able, some of them, to be molded into soldiers of Boko Haram.

Ultimately, what is perhaps most important to recognize — alongside all of the ways that the socioeconomic situation in Nigeria, presently and as a result of its historical foundations, has opened within the state and the community and in the lives of unemployment, undereducated, impoverished people a void, a space in which the seeds of Boko Haram could flourish — is that these feelings of frustration and this sense of marginalization are entirely understandable. The anger and disillusionment is wholly warranted. There will never be justification for what Boko Haram has done to the 
Nigerian people (as well as those in Niger, Chad, and Cameroon), and yet it must be noted that “these 'extreme' movements of protest (even Boko Haram) articulate real concerns, even ideals, at the grass-roots that are unwise to ignore" (Last 2012, 1). And yet the various governments of Nigeria, both colonial and independent, have ignored these concerns for too long. In many cases, one or more of the different iterations of the Nigerian government is the root cause of these concerns. Because the responsibility for the difficult socioeconomic reality can, in large part, be assigned to the state and its failure to provide basic services and employment opportunities, these factors must necessarily be examined alongside a number of political factors going as far back as when Nigeria gained its independence more than half a century ago.

\section{2 - Religion, politics, and power in Nigeria since 1960 and its effect on Boko Haram}

When Nigeria gained its independence in 1960, it was a nation already affected by deep divisions within its society, between north and south, Muslim and Christian, as well as tribal, ethnic, and linguistic divisions that would challenge the cohesion of the state. With a government and civil service that had, during the colonial period, given preference in filling its ranks to southern Christians with Western-style education, Nigeria's first independent government inherited a citizenry that, in the northern regions, already felt a sense of disenfranchisement and alienation. This was a fractious beginning for the country that would lead to a decades-long period of unrest and instability within the government until military regimes finally gave way to a democratically elected (though no more stable and no less corrupt) political leadership. Since independence, Nigeria's political structures have continuously affected, and been affected by, the country's religious divisions.

Religious identities and ideologies have driven a number of attempts to gain political and military power since 1960. Successful military coups toppled the central government in 1966 and 1985, and two more attempts were narrowly rebuffed in 1990 and 2009 (Campbell 2013, 35; Ona- 
pajo 2012,49). Military officers of one religious identity engineered each of these coups in attempt to overthrow a government ruled by members of the other. Christian or Muslim, the officers behind the coups were "motivated by the conviction that the distribution of political power and resources in Nigeria is heavily weighted against" whichever religious group is not in power at the time, and "by a desire to correct the perceived imbalance" (Ibrahim 1991, 135). Even after the transition from military to democratic rule in 1999, it would seem little has changed.

Immediately upon taking office, Olusegun Obasanjo, Nigeria’s first democratically elected president, began restructuring key positions in the government, military, and police and security agencies so that Muslim cabinet members and political officers were replaced with Christians who were more religiously aligned with the president (Onapajo 2012, 53). In addition, he "introduced a new civil service regulation that limited promotion of employees who did not possess a university degree," a ruling that seemed to many Muslims to be directly favoring Christians with far greater access to Western-style education (Umar 2012, 134-135).

As the second term of his presidency was drawing to a close, Obasanjo attempted to change the constitution to allow for a third term. Though he failed, he managed to handpick his successors: Umar Musa Yar'Adua, a Muslim, as president and Goodluck Jonathan, a Christian, as vice president. On the surface, installing a Muslim in the presidency appeared to be a power-sharing concession, but the reality was yet another instance of religiously-based political manipulation. Yar'Adua was in poor health even prior to his inauguration, suffering from a persistent (and ultimately fatal) heart condition. Well aware of this, Obasanjo's plan was to remain behind the scenes, effectively continuing his rule alongside his fellow Christian Jonathan. When Yaradua's health deteriorated to the point of being unable to govern, Obasanjo’s “extra-constitutional” machinations gave Jonathan an interim presidency in 2010 without having to go through the election process (Campbell 2013, xxii). 
Until this point, an unofficial pact known as a zoning agreement had been in place in order to rotate the presidency between a Northerner and a Southerner, in effect alternating the presidency between a Muslim and a Christian. Because Obasanjo had served two consecutive terms from 1999 to 2007, the 2011 elections should have brought a Northerner to the presidency. Instead Jonathan unilaterally ended the agreement and retained the presidency, a move that deeply alienated the Northern Muslim establishment (Hill 2012, 59; Onapajo 2012, 54). The majority of voters in both the 2007 and 2011 elections cast their ballots along strict religious lines, encouraged to do so by many of Nigeria's leaders, both political and religious, Muslim and Christian (Campbell 2013, 63; Umar 2012, 134).

The weakness of the administration of Goodluck Jonathan and its inability to bring the insurgency to an end or even to quell the violence provided ample opportunity for opposing politicians to criticize those in power and to burnish their own reputations in comparison. This is especially true in the case of certain northern politicians — Ali Modu Sheriff and Buji Foi being the most notable examples — who provided financial support to Mohammed Yusuf and the early iterations of Boko Haram. While it is possible this support came from a sense of ideological alignment, it is more than likely it was simply an attempt to further erode the power and authority, both perceived and actual, of the southern Christian leaders in power. Because the political maneuvering and machinations of those in power or who would seek to gain power occurred largely along religious and north/south lines — with significant emphasis on religious identity — religion, politics, and power in Nigeria have become undeniably and possibly irreversibly interconnected.

\section{3 - State failures, corrupt and un-Islamic leaders, and the void filled by Boko Haram}

The fact that there was little socioeconomic improvement after the transition from military to democratic rule and the persistence of "dire economic stress, the greed, corruption, unemploy- 
ment, naked poverty all combined into a living testimony of the failure of the modern statecraft in northern Nigeria" (Barkindo 2013, 37). This failure created a "political and moral vacuum" which in turn "opened up great political opportunities that were seized by the Islamists, who established a social base by offering social services that the various states have failed to provide ... [and] linked the corruption, authoritarianism, human rights abuses and moral degeneracy (associated with the importation of Western cultural commodities such as television serials) of the existing state elites to their inability to provide adequate social services and economic opportunities for new entrants into the labor force" (Lubeck 1999, 13).

It becomes obvious, then, that that instability provided the opportunity for certain members of the northern Islamic leadership, including Mohammed Yusuf, to step in where the state had left a void and to begin developing their antiestablishment platforms. The perception that the newly democratic government was a tool of southern Christians acting in their best interest to the detriment of northern Muslims furthered northerners' turn towards religion and religious institutions since, “when repressed by authoritarian regimes, Islam's civil society organizations form a parallel organizational alternative to the state" (ibid, 14). As a result, "Boko Haram seemingly became an attractive platform for a political opposition experiencing fears of arrest, harassment or intimidation" (Barkindo 2013, 37).

On a general level, that Boko Haram was established and developed within — and as a result of — such a complex, religiously-infected political climate can be understood though the "political process model" as articulated by Lubeck $(1999,8-9)$. The political process model involves six essential factors that, in combination, allow for the development and success of an insurgent group opposing the existing governmental authority. First is the existence of broad socioeconomic and political changes that "create social instability, disrupt existing power arrangements, create status inconsistencies and thus offer opportunities for new actors desiring to restructure existing power rela- 
tions." This leads into the second factor, the new and expanding political opportunities, created by that instability and disruption, that begin opening up to members of an aggrieved or oppositional group. The third factor of the political process model is the oppositional group's dependence on the strength of local and indigenous organizations or community groups. In the Islamic-majority northern region of Nigeria, this would be the ability to mobilize "the vast networks of mosques, schools, teachers and 'pious foundations' (waqf) to heighten communal solidarity, to provide welfare services and to support the Islamist political program.”

Fourth, the oppositional group must tap into the resources these indigenous community organizations can provide, thereby connecting them to the growing insurgent movement. In doing so, the oppositional group gains both a "membership base" and, perhaps more importantly, a "veneer of legitimate cover." The fifth factor involves what can be called the cognitive liberation of the community within which the insurgent movement is growing. The successful growth and continued implementation of the insurgency is dependent upon the construction of "an oppositional, insurgent consciousness, one that can be reinvented as a meaningful oppositional culture liberated from the constraints imposed by the ongoing institutionalized discourse" through which the leaders of the insurgency become able to "convince members to believe that, if they act collectively, they can create, to some degree, highly desired outcomes." In the end however, the sixth factor determining the success of the oppositional group is the response of the institutional authorities against which the insurgency is directed.

More specifically, the success of the insurgency is highly dependent upon "the capacity of the now threatened institutionalized groups (i.e. secular elites, the post-colonial state, the Western powers) to respond effectively either by concession or repression to the demands of the insurgents." In this area the Nigerian state has failed almost completely. The military and police forces have consistently demonstrating their inability to defeat Boko Haram and to protect civilians — in fact, even 
to simply not kill innocent civilians — while the government continues failing to provide to its citizens the exact same services and opportunities that first fostered the development of Boko Haram.

The violence with which the state has attempted to quell the insurgency of Boko Haram and the failure of these actions — also has historical parallels from the early nineteenth century. Again according to Last $(2013,15)$, authorities attempted to suppress through violent military campaigns the strains of dissent taking hold. This only served to exacerbate the issues, however: "An outright military attack on the dissidents did not work for the authorities as they expected. The dissidents had enough local support at the grass-roots to survive for several months not just attacks but also famine. Second, by attacking the dissidents, the authorities altered the overall character of the dissenters, who attracted to their cause otherwise jobless men who law in the fighting the chance to loot ... Thus war transformed dissent—and created acute dissent among the dissenters themselves ... It is as if dissent had been put out to franchise, with some dissidents less idealistic, more violent than others. The problem is that the more violent are apt to be the more successful politically, and it is they who spark off both antagonism from overt enemies and despair among their original colleagues." Though recounting events that took place two centuries ago, this could just as easily be an account of the early clashes between the Yusufiyyah or Boko Haram and the Nigerian military and police forces.

That the more violent dissidents were more likely to find greater success in their campaigns than their erstwhile colleagues and supporters, and that they were the ones inviting the violent state responses - though not always or not necessarily the ones incurring the violence - was also repeated in the current crisis. In cracking down on the Yusufiyyah, the state only deepened the sentiments that led to the dissent in the first place, hastening the transformation of dissent into insurgency while failing to address the root causes of socioeconomic despair and religious divisions. The state was further separating itself from the Muslim community, becoming "an over-powerful, alien 
layer which individual pious Muslims could properly resent" (ibid 26). Furthermore, "in today's Nigeria, when the politicians who run the 'state' are considered corrupt, the alienation from the Nigerian 'state' can be both deep-seated and widespread: a group like Boko Haram are thus able to tap into a rich stratum of dissent" (ibid).

The insurgency of Boko Haram is far from the only dissident uprising that the Nigerian state has had to combat since its independence. Other internal, regional conflicts have also played a large part in the near-failure of the Nigerian state (Hill 2012). As Campbell (2013, 46-47) notes, nonreligious conflicts in Nigeria are often assigned religious labels in order to increase their perceived importance or to shift blame to a certain religious group. In this same way the blame for some skirmishes, attacks, and criminal activities has been assigned to Boko Haram even in instances where there is neither evidence nor direct claims of responsibility from Boko Haram leaders connecting them to those events.

The state's responses to the two major internal conflicts of the 21 st century — the insurgency of the Niger Delta region in the South and that of Boko Haram in the North — highlight the harmful effect of describing complex conflicts in strictly religious language while avoiding the political currents that play a significant role. Military, police, and security forces responded to both insurgencies with overwhelmingly violent crackdowns. But the conflict in the Niger Delta region, seen as an economic and political one, largely ended when the state set up development boards and patronage and employment schemes for militia fighters from the region, although there has been a reemergence of conflict in the area in recent years. The political and economic factors in the conflict with Boko Haram have been ignored by the state however, and it is generally cast as a fight between secular modernism and religious extremism. It is, again, through this sort of "culture talk" that certain perspectives actively avoid political, economic, and historical factors, placing the responsibility for the violence on culture and religion. 
The state's response to Boko Haram has been violence followed by violence, justified by the supposed understanding that these religious extremists are outside the realm of logic and impossible to be reasoned with, that their violence can only be met in kind. The amnesty programs the military has offered for former Boko Haram soldiers who undergo deradicalization programs have been countered by the extrajudicial arrest and detainment — arrests that are often made without evidence, detainment in squalid and ultimately deadly conditions — of people suspected of sympathizing with or having connections to Boko Haram. And sexual and physical abuse is rampant in the camps set up for internally displaced persons (IDP) and staffed by soldiers, police, and members of vigilante groups (Matfess 2017). Despite a few recent military successes, the state's actions as a whole have served only to further alienate much of the northern population who saw in the response to the insurgency indiscriminate attacks on Muslim civilians by Christian-majority state forces (Aghedo and Osumah 2014; Hill 2012, 26-32; Umar 2012). The state's failures have furthered the spread of the rich stratum of dissent taken advantage of by Boko Haram.

The dissidence of many Muslims in northern Nigeria is expressed in a number of different ways, with Boko Haram being only the most visible and destructive. The state's initial violence towards the Yusufiyyah, prior to the group becoming the version of Boko Haram today, and the fact that the violence caught thousands of civilians in its crossfire, that large numbers of citizens have been arrested and are being kept in custody indeterminately as alleged suspects or supporters of Boko Haram, often with little evidence, that the government bulldozed the houses of Boko Haram members and those of their families, has only deepened the despair and alienation of northern Nigerians. As a result, even people who would not support or join Boko Haram outright have come to engage in a form of "“petty dissent' ... [that] nonetheless can be transformed into something much more dangerous by, for example, offering over time tacit support to more overt dissidents in the neighborhood" (Last 2012, 24). 
Sympathy for Boko Haram, or at the very least an understanding of the issues and frustrations that set off the initial dissent that blossomed into the insurgency, may lead people to refuse assistance to police forces searching the cities and villages for Boko Haram members, for example. In other words, there has been established something of a vicious cycle in which the state's unsuccessful, violent crackdowns deepen a common sense of disillusionment which prompts further dissidence and more ways of expressing that dissidence, which in turn prompts further violence from state forces, and so on. In recent years, this may be of less significance as the common support for Boko Haram has waned almost entirely in the face of their wholly indiscriminate violence and as the state forces have at the very least made some attempts to avoid civilian deaths and the extra-judicial killing of suspected insurgents while in custody. What remains to be seen is whether or not the Islamic State-aligned faction of Boko Haram led by Abu Musab al-Barnawi can regain any popular support by focusing its attacks on Western and military targets. After so many years of death and displacement however, this may be unlikely.

Ultimately, despite the attempts by state to contain the violence of Boko Haram and its own forces, the result of the military campaigns has been an exacerbation of some of the issues - social, economic, and political — that sparked the dissent at the root of the insurgency in the first place. In the fight against Boko Haram, just as it was in the early 1800s, "the use of force to stamp out overt discontent has never been wholly successful: the nodal points around which discontent reconstitutes itself as violent protest can (sometimes) be eliminated, but the aftermath is usually the dispersal of the dissidents who re-group for self-righteous revenge" (Last 2012, 32). In this case, that nodal point was Mohammed Yusuf, eliminated by security forces while in custody. The aftermath was the disappearance from public view of many of his followers, only to reemerge as Boko Haram. Under the leadership of Abubakar Shekau, the group was dedicated initially to self-righteous revenge, but has 
since dedicated itself only to violence and the destruction of the Nigerian state, of Christians and Muslims, and everything else that might stand in its way.

When the government is failing its citizens, and failing certain groups of them more so than others, those citizens are forced to look for some other existing structure or entity to take the place of the state, or to seek to create a new apparatus through which services could be provided, either by working within the state structure as it exists or by attempting to tear down or overthrow the current structures and replace them with something new. In Nigeria — as, arguably, in most countries around the world — people have most often exercised this first option, turning towards religion for support, for guidance, for solidarity and community, for reason and a lens through which to make sense of the world. This was where Mohammed Yusuf stepped in and found space in which to gain power and influence. But when Abubakar Shekau took over, it was with the intention, at least initially, of overthrowing the state and replacing it with something new.

Mohammed Yusuf was aware of the need for some sort of structure to take the place of the governing structures of the state, perhaps not in a formal legal or political way but certainly in a de facto sense in the eyes of his followers. And, importantly, he was also aware of the need for the provision of actual social services, a responsibility that belonged to the state and, because it belonged to the state, went unfulfilled. Before coming to be known as Boko Haram, as noted previously, Mohammed Yusuf and his followers from the group Ablulsunna waljama'ah hijra, commonly known as the Yusufiyyah, began providing some of the social services not being provided by the state, along with small-scale economic programs to assist the poor in Maiduguri (Hansen and Musa 2013, 289). This had the effect of increasing the standing of Yusuf and his followers within the community while also seeming to justify the perception that the state's failure to provide to its northern citizens in equal measure as it did for those in the south was in fact a religiously-motivated intentional dis- 
parity. Frustration with the state solidified as non-governmental Islamic leaders stepped in to the void left by government.

Yusufs direct participation in the implementation of Sharia law with the Borno State government is important to note because of the effect that movement had on the religious and political climate of northern Nigeria and, as a result, in the establishment and success of Boko Haram. Initially, the success in getting state governments to formally adopt a version of Sharia law likely may have empowered more orthodox Islamist groups and individuals through the sense that they were making strides towards a more Islamic form of government. This was for many, it seemed, a major step forwards, away from the failures of the secular democratic state.

It legitimized certain Islamic efforts at self-determination and at regional and judicial autonomy, such as had been allowed through the indirect rule of the colonial period. As such, the implementation of Sharia was defined by its proponents as a "restoration," which situated the movement within the anti-imperialist, nationalist discourse of Islam and in opposition to the discredited secular nationalist legal system introduced by British imperialism (Lubeck, Lipschutz, and Weeks, 2003). The sense of self-determination that Sharia allowed was critical for many Islamists because "it is the secular state's aspiration to total social control that shapes the Islamists' political imagination, partly because even their cultural activism tends to come up against state regulation” (March 2015, 17.9). Tied into the state's construction and manipulation of religious identities as this aspiration is, it is little wonder then that the dissident response would involve a desire for self-determination.

Yusuf's involvement in the implementation of Sharia would have had the added benefit, for him, of providing him with legitimacy as a politically and socially active religious leader. This would subsequently increase his ability to attract and retain followers who believed that he could help them achieve their goals, or who believed his alternative to the government would be a viable one. To some extent, his involvement with Islamists and the implementation of Sharia may have elevated his 
reputation further. Islamist movements seem to be most active when it comes to the opposition of social control by the state, which is indeed what the push for Sharia in northern Nigeria was. On a global level, "by seizing the mantle of anti-imperialist nationalism, a discourse formerly controlled exclusively by nationalist and leftist movements, Islamism has become the world's most extensive and militant anti-systemic social movement ... [and] Islamists have become the best organized political force in an urban milieu marked by declining state capacity to deliver services and/or any other alternative developmental model" (Lubeck 1999, 16).

By involving himself with Islamist groups and working publicly towards the implementation of Sharia, Mohammed Yusuf began establishing himself as an agent of change and a potential leader of an alternative governing structure. As the implementation of Sharia law progressed, however, some more staunchly orthodox Nigerian Muslims felt that the form of Sharia being implemented was largely moderated from what they would consider "true" Sharia. They were left disappointed, doubting the commitment Muslim political leaders felt toward the idea of a true Islamic government, believing their lack of commitment made them un-Islamic, and hardening their own beliefs in response. Here again, it appears that Mohammed Yusuf came out as a leader. Despite having worked within the establishment to help implement Sharia and despite appearing to have aligned himself with a broader Islamist movement, he later had a falling out with the political leadership.

After that falling out, Yusuf began to preach "a return to the original sources in Islam and called for the rejection of all currents from abroad," disputing the religious commitment of Islamic political leaders and railing against the state of which the "moderated" form of Sharia that he helped usher in was a part (Barkindo 2013, 36). In short, it was at this point that Yusuf started becoming more strictly orthodox and solidifying his ideologies into what would become those of Boko Haram. His reputation, which had been growing in certain circles due to his involvement with the political 
Islamic leadership, continued to grow within other circles when he ceased being part of the establishment and turned against it and painted it as un-Islamic.

Alongside the importance Islamists place on political Islam is the importance of community and a solidarity amongst believers. As a total way of life and system of behavioral guidance, "Islamism reinterprets and elaborates on already existing discursive practices integral to the everyday life of Muslims." In doing so, “it captures and mobilizes for essentially modern ends a deeply felt desire to belong to a transcendental community-the global umma" (Lubeck 1999, 16). Indeed, the importance of the umma plays a large role in the intolerance that groups like Boko Haram have towards Muslims they see as being un-Islamic. Boko Haram initially limited, to an extent, its targets to non-believers, infidels, military and police forces, and the political and economic elites they see as responsible for the socioeconomic distress of northern Nigerians. But in recent years, as its attacks have been equally directed at other Muslims, the rhetoric of its leaders has likewise focused on castigating Muslims who do not support the insurgency.

In light of the importance of community and solidarity, an inevitable question would arise of how Boko Haram could justify, within their ideological construct of Islam, killing other Muslims. It is possible that part of the answer to this question lies with the modern technology and instruments of insurgent warfare, "that the use of guns and bombs (while clearly not considered 'boko') raises fewer problems: very little exertion is involved, so mature adults can kill easily without a struggle, and in any case mature adults can always order their juniors to use the revolvers or AK-47s or set off the bombs" (Last 2012, 33). The ease with which one can take a life, or in fact dozens of lives at once, may have simplified warfare sufficiently enough for the members of Boko Haram so that it is "somehow no longer improper for an almajiri to kill a Muslim in this modern, calm manner." While it is almost certain that the available military technology plays a role, what is more important in justi- 
fying violence against other Muslims is the way that Boko Haram portrays the relationship between non-member Muslims and the broader Islamic community.

In certain respects, it is these "erring Muslims," rather than Christians or non-believers, who seem particularly odious to the members and leaders of Boko Haram. Not being born into Islam, or being raised in or a member of a different religious tradition, is unacceptable, but to fail or refuse to conform to the guiding tenets of behavior set out within Islamic doctrine is far worse. Those Muslims that Boko Haram sees as "erring," as un-Islamic or as backsliders, are worse than non-believers because they are not being loyal to the umma, the global Islamic community, nor to the local Islamic community, the jam'a. To break away from the community, or Boko Haram's conception of the community, “is 'treason', betrayal, a breach of trust” (Last 2012, 23).

The Islamic community, the umma as well as the jam'a, "is all-important—it brought you into being and brought you up, it sustains you through life and prays for you in death; it is the basis of your humanity ... [and] to leave it, even symbolically, through misbehavior or, worse still, through conversion is wholly unacceptable." The members of Boko Haram have thus been betrayed — not only by a secular government that has marginalized and disenfranchised them but by their fellow Muslims who they believe have abandoned them, deserted the Islamic community, and discarded the solidarity that is expected to go with it. In doing so, the Muslims who eschew Boko Haram's ideology and its idea of the Islamic community become far more threatening to that ideology and community and to the authority of those, like Abubakar Shekau, who represent them. This is another connection between religion and power that informs the insurgency and the threat to power helps explain the willingness of Boko Haram to target and attack other Muslims.

That threat and the sense of betrayal felt by members of Boko Haram has likely also affected the group's perception of itself. With other Muslims seen to be abandoning the umma, backsliding into un-Islamic lives, Boko Haram becomes more hardened ideologically, believing more strongly 
that they are true Muslims, and that there is no room for compromise with innovations outside of their reading of Islam. There is no need for members of Boko Haram to try to reconcile their ideology with that of the majority of Muslims around the world who have room within their systems of belief for tolerance and diversity. For everyone else however, it is important to be reminded that "it is not self-evident that those most vehement against non-believers are the most deeply committed to religious practice: intolerance need not be a reflection of a person being any more God-fearing than others. Indeed ... it has been the most 'spiritual' Muslims who are the most tolerant of other faiths, in part because they seemed so utterly secure in their Islamic faith: nothing from outside could possibly disrupt that faith" (Last 2012, 23). The members of Boko Haram may believe they are better Muslims than those they have killed, but as with so much of Islam, that is the subject of debate.

\section{4 - Situating Boko Haram within an increasingly interconnected world}

In the end, it is important to briefly recognize that while Boko Haram is a product of regionally-specific contexts and histories, and while its insurgency remains highly localized, it is also a product of broader global forces in motion around the world. Each of the factors mentioned previously — religious, political, historical, geographical, and socioeconomic — can also be situated within the wider, global arena. Certainly there is the spread of Islam from the Middle East across north Africa, and the colonization by British imperialists that brought Western structures of governance into another part of the world. There are also Boko Haram's movements into Chad, Niger, and Cameroon and its alignment with the Islamic State and other groups in Africa and the Middle East. Beyond this, however, are global factors that would appear to have little to do with Boko Haram at all, arising out of the global interconnectedness that has been growing exponentially over the last few decades. 
This trend towards globalization has brought new economic and market forces into northern Nigeria, has facilitated communications networks among Islamist groups around the world, and ultimately has helped weaken the Nigerian state's authority at home as it seeks to make a more prominent place for itself in the international community. Each of these aspects has been touched on in the previous sections and chapters, but it is important to recognize that they are all products of modern globalization. In exploring these connections, it becomes clear that Boko Haram's existence and the violence and terror it has sown across northern Nigeria should be considered a global problem — or globalization problem — almost as much as a local one.

For its understanding within the scope of this project, a useful definition of globalization is as "a set of interrelated processes that extend, deepen, and speed up the 'interconnectedness' of spatial organizations, social relations, and transaction flows (economic, cultural, social) across increasingly porous national borders ... [that] promotes flexible economic, social, material, and cultural networks within and around the territorially-embedded bureaucratic national state ... [and] is embedded as both cause and effect in the rise of competitive free market policies — often called 'neoliberalism"' (Lubeck, Lipschutz, and Weeks 2003, 7-8). In other words, there are political, economic, social, and — most importantly — technological developments and systems which, working with and through each other, make it far easier for people and systems around the world to connect with each other in order to share information, to debate and discuss, to engage in financial and cultural exchange. Because of the ease with which one can connect transnationally, the networks created through these exchanges circumvent the nation state and at times even undermine its authority and, especially in regards to the effect of global market forces, its ability to provide services to its citizens and encourage economic growth.

The fundamental problems embedded in and arising from Nigeria's oil industry are among the primary examples of the ways in which globalization has allowed for the rise of Boko Haram. In 
2013, Nigeria was the world's eighth-largest oil producer, and petroleum and petroleum products accounted for 95 percent of the nation's export earnings, along with 80 percent of its budgetary revenue. Because of the importance of the oil industry to Nigeria's overall economic growth, it has been heavily reliant on making itself a part of the larger global economy. Indeed, a fifth of the United States' oil imports originate in Nigeria (Oshikoya 2008, 41), and oil accounts for 90\% of Nigeria's exports to China (Kashi 2013). Thus, "instability in world oil supplies and the critical link of oil to the international economy has made Nigerian - and more generally African - oil to be more strategic" (Ikelegbe 2006, 24). While its rich natural resources have helped the Nigerian economy grow rapidly overall, the over-dependence on oil puts it in a precarious position.

The Nigerian and the global economies have been shaken numerous times before by oil price shocks, and a failure to diversify could lead to an economic crisis for the country. The volatility of oil prices in 2008 alone provides an excellent example of how quickly economic fortunes can change. Throughout the year, the price of oil changed almost weekly; at the beginning of the year it was slightly less than $\$ 100$ per barrel, by the middle of the year it had risen to $\$ 140$ per barrel, and by the end of the year it had crashed below $\$ 40$ per barrel (Umar and Abdulhakeem 2010, 40). When an economy is as dependent on oil as Nigeria's however, it does not take such wild variations to cause massive effects: "For instance a US\$1 increase in the oil price in the early 1990s increased Nigeria's foreign exchange earnings by about US $\$ 650$ million (2 percent of GDP) and its public revenues by US\$320 million a year" (ibid, 39). Equally as important is the corruption and economic inequality that the oil industry has bred over the years as detailed in chapter one.

That deep corruption and venality, the theft of revenue that could be used for the benefit of the Nigerian population across the country, the strong patronage networks that keep much of the remaining revenue in the southern region, and the deepening inequality that results all have to be factored into a broader understanding of the development of Boko Haram. More importantly for 
this section, however, are the global connections that Nigeria's oil industry has fostered. Oil price shocks are triggered by situations far removed from Borno and the members of Boko Haram, but nonetheless feed back to underpin its insurgency by damaging the economy as a whole. Boko Haram's hatred of Western or un-Islamic thought and structures of authority is at odds with the Nigerian government's ties to the United States, its European trading partners, even China, and those ties erase Nigeria's legitimacy in the eyes of Boko Haram even further. If movements towards sustainable energy decrease the need for oil, or if China's economic growth slows and, with it, its need for Nigerian oil, Boko Haram could be strengthened — ideologically if not physically — by the economic damage that would follow.

There are numerous other examples of ways that the rise of Boko Haram has been, or could continue to be, affected by globalization and international forces beyond the scope of the insurgency itself. Most of those examples are, regrettably, beyond the scope of this project as well, however. But the impact of globalization is a thread that can — and should — be seen woven throughout the previous sections and chapters. The ease and speed with which people can travel has allowed Boko Haram to adjust and improve its tactics, sending members to train with other groups outside of $\mathrm{Ni}$ geria. Technological advances need to be recognized for the ways in which they can allow, for example, for the Islamic State to communicate instantaneously with Boko Haram via the internet, social media, video, or cell phone. Even with Muhammed Yusuf's death, the dissemination of a video taken on a cell phone hastened the outrage and sparked the quest for revenge that marked the beginning of Boko Haram under Abubakar Shekau. The list goes on.

It should be noted that this section is not meant to be any sort of indictment against technological advances or the increasing interconnectedness that has come to define globalization at the beginning of the twenty-first century (although the Nigerian economy must continue to be diversified away from its dependence on oil if it is going to continue to grow). Nor should this section be 
read as advocating for any sort of isolationism. Globalization and all the different facets that surround it have arguably resulted in more positive developments than negative. If engaged in fairly, international connections between states and individuals alike can be beneficial for everyone involved. Rather, the recognition of the effects of globalization on Boko Haram and its insurgency is critical because it should serve as a reminder that Boko Haram is not simply a Nigerian or a West African problem.

The foundational aspects of the crisis extend far beyond the region in which it is taking place. Most of the responsibility for the devastation that has taken place lies, as it should, with the leaders of Boko Haram. Some of the responsibility lies with the members of Boko Haram, though one could argue that for many of them, the blame should be largely absolved in consideration of the fact that their entire lives have been fluctuations of uncertainty, affected by numerous forces beyond their control. Much of the responsibility lies with the Nigerian state - all colonial, post-colonial, and democratic versions - for its myriad failures. But the effect of global forces that were largely set in motion by the economic and military powers of the United States and Europe means that they must bear some of the responsibility as well. Boko Haram - the insurgency, the violence and displacement, the food shortage and starvation — is a global problem.

\section{5 - Conclusion}

Three fundamental questions need to be answered in order to understand Boko Haram. As simply as possible, these questions are: why are they doing this? Why is this happening here? And why is it happening now? The present conditions laid out in this chapter provide a comprehensive — if unfortunately not entirely exhaustive — context in which to the last two of these questions. The conditions in Borno and in the region as a whole, including the areas of Niger, Chad, and Cam- 
eroon in which Boko Haram has operated, represent a combination of factors set in motion years ago that have coalesced at just the right time.

The region has been marginalized by its own government for years, while it was part of the colony and as part of an independent nation. It received neither the attention nor the funding that the southern regions did, not the hospitals or schools or revenues from the oil industry. Religious divisions and identities were institutionalized, and the region remained heavily Muslim, steeped in a history of Islamic education, scholarship, authority, and dissent. The state failed to provide basic services, became defined by corruption and incompetence, and its leaders manipulated and took advantage of its citizens. The number of people living in abject poverty in the region increased dramatically, both objectively and in terms of the economic inequality they faced in relation to the elites. Unemployment rose, and more than half of the population never received any formal education. Families from rural areas sent children to cities as almajiri, young men were sent to find income or came of their own volition. Frustration and unrest were inevitable. And in the midst of all of this, a charismatic preacher named Muhammed Yusuf was increasing his standing amongst the Islamic communities of Maiduguri, while Abubakar Shekau waited for his turn.

It came when Yusuf was illegally killed by police forces, the point in time at which everything seemed to turn. The state had failed its citizens before the insurgency, and it would fail again in its earliest days, bolstering popular support for the militant group that was fighting back against an oppressive political structure. By the time Boko Haram turned against ordinary civilians, including other Muslims, it was far too late for the state to possibly address the myriad conditions that had allowed the physical and ideology space for the insurgency. And it was clearly far too late — and the state far too incompetent — for Boko Haram to be contained.

In the end, just as these factors facilitated Boko Haram's establishment and the beginnings of its insurgency, so did they allow for its duration, coming up on a decade of violence and destruc- 
tion. It is impossible to understand Boko Haram if any one of the factors analyzed in this chapter along with the historical precedents and religious or ideological contexts outlined in chapter two is not taken into account. Examining every facet of the situation, complex and convoluted and messy as any conflict in the world at the moment, is the only way to gain a full understanding of Boko Haram. And only with a full understanding of Boko Haram can its insurgency and the crisis it has caused possibly be brought to an end. 


\section{Conclusion The fight for the future}

This project has sought to demonstrate that no single factor, variable, or theory can be used independently to fully explain the rise of Boko Haram and the motivations behind its insurgency. To focus too closely on ideas of ideology, Islamic extremism, and religious violence is to ignore the fact that the members of Boko Haram have been driven to act upon their ideology by socioeconomic desperation, poverty and inequality, and very valid senses of disillusionment, marginalization, frustration, and anger. Focusing on these socioeconomic factors necessitates an examination of the geographic and political contexts, historically and in the present reality, and within this examination the failures of the state become clear. These are failures of military and political nature, including the atrocities committed against civilians and the political manipulation of religion, and of a socioeconomic nature, including the failure to provide citizens - particularly in the northern regions - with access to education and health care, employment and social services.

The colonial authorities set in motion a chain of events that has reverberated to the present day in the marginalization of northern Nigerians and the institutionalization and normalization of Islamic authority in the northern regions. The independent military and democratic Nigerian governments have perpetuated the disillusionment of their citizens through corruption and poor governance, prompting initial popular support for Boko Haram. Coming full circle, the socioeconomic realities and the failures of the state have hardened the ideological righteousness of Boko Haram, reinforcing the religious core of its insurgency. Each of these factors is an individual thread, all of which have been braided together into the rope that is Boko Haram and the crisis in northern Nigeria. It is possible to pull out an individual thread to examine it more closely, but it will still be fully entwined with each of the others and each one is ultimately insufficient on its own. If Nigeria is to 
defeat Boko Haram and to keep from failing entirely, it must address each thread that woven throughout the insurgency.

For most of the first decade of the twenty-first century, Nigeria was a nation on the rise, increasing its standing on the global stage on the basis of the rapid growth of its economy spurred by the oil industry, the rapid growth of its already-massive population, the popularity of its films. Its elections were largely peaceful, if not transparent and fair. It had arguably surpassed South Africa as the continent's giant. Since then, Boko Haram has destroyed a massive part of the country, further shaken the public's belief in the efficacy and legitimacy of its government and military, and damaged the reputation of the Nigerian state on the global stage. Subsequently the value of the naira fell fifty percent compared to the dollar between 2015 and 2016 (Wallace and Onu 2016), and the Nigerian economy entered a deep recession (Page 2016). In January 2017, eight years into the insurgency, arguing that the very existence of the Nigerian state depends on stopping Boko Haram does not seem to be an overstatement.

President Muhammadu Buhari campaigned and won the election in May 2015 largely on a promise to eradicate Boko Haram and end the crisis. Since then, he has claimed twice that the militants were on the run, defeated, crushed. In neither instance has that been true. It's unclear if Buhari believed what he was saying or was lying, was intentionally misinformed by military advisors, or if indeed they were convinced that the war was essentially won. If Buhari's statements do in fact reflect what his administration and advisors believe to be the case, they should reevaluate the metrics used to judge their success against the insurgency.

Each of Buhari's statements came as the military was taking back significant amounts of territory that had been under Boko Haram control, as in Sambisa Forest. But the majority of the attacks in the weeks before and the month after Buhari's December 2016 statement were suicide bombings, a tactic which requires little to no territory to be held by the insurgents. Whatever the 
case may be, if the state is to regain a sense of legitimacy, a good first step would be to stop claiming victory prematurely. For a state that has significantly exacerbated the crisis on its own, having its declarations of Boko Haram's defeat repeatedly followed by attacks and video statements proving the opposite does little to repair its standing in the eyes of its citizens or the world. More importantly, this repeated tendency to underestimate Boko Haram will only prolong the insurgency further.

The Nigerian state also needs to reevaluate its tactical approach to actually fighting against the insurgency. With 236 civilians killed in a "regrettable operational mistake" where fighter jets dropped multiple bombs on an internal refugee camp mistaken for an insurgent enclave, while most of the actual insurgency was being carried out by individuals or in groups of two or three, there is a rather alarming disconnect between the war Boko Haram is fighting and the one the military is fighting. One would hope the tragedy in the refugee camp, if it were to benefit anyone, would upend a pending sale of United States fighter jets to the Nigerian Air Force that would reportedly cost $\$ 500$ million, about half of Nigeria's total defense budget for 2016 (Page 2016). With over two million people displaced from their homes and 1.8 million at risk of starvation - a number that could rise to 5.1 million in 2017 (UN 2016) - there is no doubt that $\$ 500$ million would be better spent on humanitarian relief or compensation that could allow people to return to their homes. Such relief efforts should arguably be the centerpiece of the fight against Boko Haram as the number of civilians at risk of dying from starvation is exponentially higher than the number at risk of being killed by insurgent attacks. Food relief in particular must be well guarded against theft by Boko Haram (or anyone else), however.

The bombing of the internal refugee camp also highlights the critical need for increased training and logistical support not only for the Nigerian Air Force but for the rest of the multinational military coalition as well. Reforms within the military must include an examination of top leadership on down. There must be improved oversight and reevaluation of training programs. The 
state must ensure the proper use of funding, including paying soldiers salaries on time and providing them with proper supplies, arms, and ammunition. There must be legal prosecution in fair trials of soldiers involved in sexual or physical assault especially within internal refugee camps. And there must be a demand for greater professionalism for all members of the military. Furthermore, there must be an end to the arrests and detainment without proper evidence of civilians suspected of sympathizing with or supporting Boko Haram. Conditions in the barracks used as detainment centers must be improved so that children are not dying while in military custody. And the amnesty and deradicalization programs should be strengthened and extended so that all former members of Boko Haram — captured or voluntarily surrendered — can be processed and entered into the program as efficiently as possible without lengthy stays in squalid detainment centers.

To address the underlying causes of the insurgency, the state should provide job skills training programs, particularly directed towards women and teenage girls. Microfinance loan programs have been shown to be effective in helping individuals invest a small amount of money into a sustainable income-generating activity. Again, these programs have been shown to be most effective when implemented by women. The state must increase the density and capacity of hospitals and clinics in the northern region, and must provide security support to vaccination campaigns that have been targeted by Boko Haram in recent months. Likewise, the state must increase the density and capacity of schools in the northern region, and primary education at the very lease should be free for all children. And corruption and malfeasance should be rooted out at all levels of governance.

Nigeria may be on the verge of collapse, and Boko Haram's insurgency has created a humanitarian disaster on top of the lives and livelihoods already lost. The way forward will be long and chaotic and messy. And while it should not be impossible, it also does not seem unreasonable to think that Boko Haram itself will not be completely wiped out. Instead, it and the insurgency could very likely follow a similar trajectory to that of the Lord's Resistance Army in Uganda, where the 
military never fully defeated the insurgents, but pushed them increasingly further from mainstream society as their numbers dwindled along with the number of their attacks. Joseph Kony has yet to be captured but for all intents and purposes, that war has been won. Abubakar Shekau may disappear into the forest, but the war with Boko Haram could still be won.

It is easier to write recommendations in a project like this than it is to get them implemented, and the aim of this project was not policy recommendations but a fuller understanding of Boko Haram as a whole. There remains ample opportunity for further valuable research on other aspects of the crisis, specifically with a more narrowed focus as on the effect of the insurgency on women and women's effect on the insurgency, the specific conditions in the internal refugee camps including an examination of the sexual and physical assault carried out by camp guards, further analyses of the efficacy of amnesty and deradicalization programs, among other focal areas. For this project however, the hope is that some of the challenging complexities and contexts were made clearer in the development of a holistic understanding of Boko Haram. 


\section{Appendix A}

Timeline of major events involving and related to Boko Haram and its insurgency, 1968-2017

c. 1968 - 1973: Abubakar Shekau is born in Yobe State

1970: Mohammed Yusuf is born in Yobe State

1980: Maitatsine Riots in Maiduguri, Kano, and several other northern cities, and the subsequent suppression of the riots by the Nigerian military

c. 1980: Rise to prominence of Ibrahim Zakzaki whose followers were known as "Shiites" and who was known for his enthusiastic opposition to the state despite public denunciations of violence.

1980: Yusuf joins the Shiites and begins studying under Zakzaki

c. 1980 - 2002: Yusuf continues education and training under Zakzaki and later as a member of the non-violent Izala movement led by Ja'far Adam

c. 1990: Abubakar Shekau is said to have moved to Maiduguri to pursue Islamic studies

Mid-1990s: Shekau attends Borno State College of Legal and Islamic Studies where he meets Mamman Nur who would then introduce Shekau to Mohammed Yusuf

1995: Nigerian government begins monitoring activities of religious group known as Ablulsunna wal'jama'ah hijra in Borno State

c. 1997 - 2000: Shekau gains influence within the Yusufiyyah, becomes one of Yusuf's top deputies

1998 - 2000: Twelve northern states officially adopt moderated forms of Sharia law

2002: Ablulsunna wal'jama'ah hijra begins to fracture into multiple factions, a number of which increasingly call for violence against the state

Early to mid-2000s: Relations between Yusuf and Shekau become increasingly tense, characterized by ongoing debates on the use and value of violence

2002 - 2004: Growing rift and ultimate split between Yusuf and Adam

2003: Committee of sheiks elects Yusuf to lead Ablulsunna waljama'ah hijra and because of his growing influence the group becomes commonly known as Yusufiyyah

2003: Emergence of the Nigerian Taliban, a violent insurgent group subsequently suppressed by the Nigerian military

December 23-31 2003: First major instance of violent skirmishes between Yusufiyyah and police forces leave three dead and is followed by Yusufiyyah raiding and looting two police stations in Yobe

2004 - May 2009: Intermittent skirmishes between Yusufiyyah and police forces as Yusufs influence 
grows in Maiduguri and across the region

June 11 2009: Clash between Yusufiyyah and police forces resulting from enforcement of motorcycle helmet law; Yusuf pledges retaliation if the government does not respond with a solution within 40 days

July 26-30 2009: Fighting erupts in five northern states leaving between 800 and 1100 dead, 3500 displaced from their homes, and hundreds arrested including Yusuf as a military raid on the main Yusufiyyah compound in Maiduguri ends the fighting

July 31 2009: Mohammed Yusuf dies while in police custody

August 1 2009: Cell phone video of Yusuf's death and the execution of a number of civilians is posted online and spread widely across the country

Late 2009: Shekau's radical and aggressive ideologies lead him to be chosen to lead the Yusufiyyah after Yusuf's death and the group becomes commonly known as Boko Haram

December 2010: Boko Haram reemerges for the first time since Yusuf's death as gunmen raid a prison in Bauchi on December 7, freeing over 100 Boko Haram members, and 86 people are killed in a series of attacks between December 24-27 in Maiduguri and Jos

January - May 2011: Low-level guerilla warfare and sporadic attacks by Boko Haram, including drive-by shootings and targeted assassinations

May 29 2011: First evidence of increasing sophistication and capability of Boko Haram as the inauguration of President Goodluck Jonathan is marked by coordinated series of bombings in Abuja, Bauchi, and Maiduguri

June 16 2011: Boko Haram claims responsibility for an explosion at police headquarters in Abuja, the insurgency's first instance of suicide bombing, and states that the bomber was trained in Somali, the first evidence of possible international connections

August 3 2011: Government rejects possibility of negotiations with Boko Haram leaders

August 26 2011: Boko Haram carries out its most high-profile attack to date in suicide bombing at UN building in Abuja that kills 21 and marks the first attack with an international target

August 26 2011: Following bombing at UN building, the leader of al-Qaeda in the Islamic Maghreb releases statement of support for Boko Haram

November 4 2011: Coordinated series of bombings target the motorcade of the Borno State governor, two police stations in Yobe State, and the headquarters of the military's Joint Task Force in Maiduguri

December 25 2011: Coordinated attacks on churches in four northern states kill at least 41 civilians

2012: Boko Haram continues targeting churches and their congregations - at least six churches at- 
tacked over the course of the year, leaving 790 dead in Borno State alone with 200 more killed in a series of attacks in Kano

2013: Boko Haram becomes increasingly indiscriminate with the targets of its attacks

Feb 8 2013: Polio vaccinators attacked by Boko Haram gunmen, nine killed

April 16 2013: The worst massacre of the insurgency to date is carried out by police and military forces in the village of Baga - over 200 civilians killed, hundreds more wounded, and thousands of homes and buildings destroyed

June - July 2013: First instances of schools and students attacked by Boko Haram

September 19 2013: 161 civilians killed in Benishek

October 29 2013: 128 civilians killed in Damaturu

January 26 2014: 138 civilians killed in coordinated series of attacks in several cities

February 14 2014: 121 civilians killed in Konduga

February 15 2014: 106 civilians killed in Izghe

March 14 2014: Military forces execute more than 600 unarmed detainees suspected but not proven to have ties to Boko Haram

April 15 2014: 276 girls kidnapped from their secondary school in Chibok

May 5 2014: More than 300 civilians killed in Gamboru Ngala

May 20 2014: More than 120 civilians killed by car bombs in Jos

June 2 2014: More than 200 civilians killed in Gwoza

June 20-23 2014: 71 civilians killed and 91 women and children kidnapped in several villages in Borno State

June 23-25 2014: More than 170 civilians killed in series of coordinated attacks across the central region of the country, Boko Haram's most significant attacks to date carried out outside of the north

July 2014: Boko Haram leaders declared support for ISIS

November 28 2014: More than 120 Muslims killed by suicide bomber in Kano

December 1 2014: Attack in Maiduguri marks first reported instance of an attack carried out by female suicide bomber

December 13 2014: 185 civilians kidnapped in Borno State 
December 28-29 2014: First attack carried out by Boko Haram in Cameroon

January 3-7 2014: Entire village of Baga is destroyed, more than two thousand civilians killed, between ten and 35 thousand displaced from their homes

January 10-11 2015: Three suicide bombings carried out by girls suspected to be around ten years old, the first instances of children being used in attacks by Boko Haram

January 25 and February 1 2015: Boko Haram launches two failed attempts to take control of the entire city of Maiduguri in its boldest attempt to date at controlling territory

February 2015: Nigerian military is joined in a coalition by soldiers from Chad, Niger, and Cameroon and the African Union pledges 7500 additional troops

February 6 2015: First attack carried out by Boko Haram in Niger

February 13 2015: First attack carried out by Boko Haram in Chad

June 16 2015: Boko Haram claims responsibility for two suicide bombings in N'djamena, the first instance of this type of attack in the Chadian capital

June 22 2015: Start of Ramadan marked by suicide bombing in Maiduguri, the fourth suicide bombing in the city that month

July 1-2 2015: Series of mosques bombed in several northern cities

July 4-7 2015: More than 200 civilians killed in series of attacks in Chad and Nigeria

October 1-2 2015: Four suicide bombings in Maiduguri, two in Abuja

October 10 2015: Five suicide bombings in N'djamena

October 15 2015: Three suicide bombings in Maiduguri push the death toll over one thousand since the inauguration of President Muhammadu Buhari in May, 2015

October 23, November 17-18 2015: Continued series of suicide bombings across a number of northern cities

January 31 2016: Three female suicide bombers kill 86 outside Maiduguri

February 11 2016: First instance of Boko Haram targeting refugees as two suicide bombers attack refugee camp near Maiduguri

February 11 2016: Nigerian officials announce the first arrest of an ISIS recruiter in the country and the separate arrest of several members of the Nigerian army suspected of smuggling arms to Boko Haram members

May 2016: At least 150 individuals detained by military forces die in custody at Giwa barracks 
Mid-to-late 2016: Food crisis begins in earnest as markets shut down, trade in the region stalls, and farmers are forced to flee their fields; by the end of the year, 1.8 million people are threatened with starvation

August 3 2016: ISIS publication declares that Abubakar Shekau is no longer the leader of Boko Haram and has been replaced by Abu Musab al-Barnawi, the son of Muhammed Yusuf; days later, Shekau released a video confirming this change but reaffirming his role as the head of JAS

September-December 2016: Scope of the insurgency changes as Shekau's faction continues to attack civilians while al-Barnawi's focuses on Western and strategic military targets

October 13 2016: 21 girls kidnapped from the secondary school in Chibok are released to state authorities after lengthy negotiations

November 28 2016: First instance of a female suicide bomber attempting to sneak past a security checkpoint by disguising the explosive device on her back with an infant

December 24 2016: President Buhari releases statement declaring that Boko Haram is on the run, having been ousted from its last stronghold in Sambisa Forest; days later, Shekau releases a video calling Buhari a liar and declaring that the war is not over

January 17 2017: Nigerian Air Force fighter jet mistakenly bombs camp for displaced persons near the Cameroonian border, killing at least 236; two days later, Boko Haram soldiers attack the same camp 


\section{Bibliography}

Abubakar, Aminu, Don Melvin, and Stephanie Busari. 2016. "Female Suicide Bombers Kill 58 in a Nigerian Camp Meant to be a Haven.” CNN, February 11. http://www.cnn.com/2016/02/ 11 /africa/nigeria-suicide-bombing-boko-haram.

Abudulrahim, Ismail Alfa, and Michelle Faul. 2016. "2 Girl Suicide Bombers Die in Blasts Near Market in Nigeria." AP News, December 11. http://bigstory.ap.org/article/a495e2250c754 9e0b2ef0dc9742702a4/twin-bomb-blasts-near-market-northeast-nigerian-city.

Adegbulu, Femi. 2013. "Boko Haram: the emergence of a terrorist sect in Nigeria 2009-2013." African Identities 11, 3: 260-273.

Afri-Dev Info. 2015. "Education.” Lagos: Africa Health, Human, and Social Development Information Service. Last accessed February 17, 2017. http://www.afri-dev.info/.

Agbiboa, Daniel Egiegba. 2014. "Peace at Daggers Drawn? Boko Haram and the State of Emergency in Nigeria." Studies in Conflict \& Terrorism 37: 41-67.

Agbiboa, Daniel Egiegba. 2013. "No Retreat, No Surrender: Understanding the Religious Terrorism of Boko Haram in Nigeria." African Study Monographs 34, 2: 65-84.

Agbiboa, Daniel Egiegba. 2012. "Between Corruption and Development: The Political Economy of State Robbery in Nigeria." Journal of Business Ethics 108: 325-345.

Agbiboa, Daniel Egiegba, and Benjamin Maiangwa. 2013. "Boko Haram, Religious Violence, and the Crisis of National Identity in Nigeria Towards a Non-killing Approach."Journal of Developing Societies 29, 4: 379-403.

Aghedo, Iro, and Oarhe Osumah. 2014. "Insurgency in Nigeria: A Comparative Study of Niger Delta and Boko Haram Uprisings." Journal of Asian and African Studies: 1-15.

Aigbokan, Ben E. 2008. "Growth, Inequality and Poverty in Nigeria." Economic Commission for Africa Discussion Papers: no. 3.

Akinyelure, Didi. 2016. “The Six Lives of Boko Haram's Abubakar Shekau.” British Broadcasting Company, September 27. http://www.bbc.com/news/world-africa-37476453.

Akpan, Uduak. 2015. "Technology Options for Increasing Electricity Access in Areas with Low Electricity Access Rate in Nigeria." Socio-Economic Planning Sciences 51: 1-30. Last accessed February 17, 2017. doi: 10.1016/j.seps.2015.05.001.

Al Jazeera. 2016a. "Buhari: Last Boko Haram base taken in Sambisa Forest.” December 24. http://www.aljazeera.com/news/2016/12/buhari-boko-haram-base-retaken-sambisa-forest161224125809113.html. 
Al Jazeera. 2016b. "Boko Haram Attack: Children Burned Alive in Nigeria.” February 1. http://www.aljazeera.com/news/2016/01/boko-haram-blast-kills-scores-nigeriamaiduguri-160131140615844.html.

Ali, Mohsin. 2017. “Boko Haram Attacks.” Al Jazeera, January 16. http://www.aljazeera.com/ in depth/interactive/2017/01/map-boko-haram-attacks-170116191820253.html.

Allen, Nathaniel. 2016. “Charting Boko Haram's Rapid Decline.” War on the Rocks, September 22. https://warontherocks.com/2016/09/charting-boko-harams-rapid-decline.

Almukhtar, Sarah. 2015. "How Boko Haram Courted and Joined the Islamic State." New York Times, June 10 .

Amnesty International. 2014. "Nigeria: Government Knew of Planned Boko Haram Kidnapping but Failed to Act.” Last modified May 9. https://www.amnesty.org.uk/press-releases/nigeriagovernment-knew-planned-boko-haram-kidnapping-failed-act.

Amnesty International. 2016. "Nigeria: No Justice for the 640 Men and Boys Slain by Military Following Giwa Barracks Attack Two Years Ago.” Last modified March 14. https://www.amnesty.org/en/press-releases/2016/03/nigeria-no-justice-for-the640-men-and-boys-slain-by-military-following-giwa-barracks-attack-two-years-ago.

AP. 2017. "At Least 4 Killed in Trio of Suicide Attacks in Nigeria." New York Times, January 25. Last Accessed January 30, 2017. https://www.nytimes.com/aponline/2017/01/25/world/Africa /ap-af-nigeria-suicide-bombings.html.

Asad, Talal. 2007. On Suicide Bombing. New York: Columbia University Press.

Awofeso, Niyi, Jan Ritchie, and Pieter Degeling. 2003. "The Almajiri Heritage and the Threat of Non-State Terrorism in Northern Nigeria: Lessons from Central Asia and Pakistan." Studies in Conflict and Terrorism 26, 4: 311-325.

Babalola, Oluwatosin. 2013. "Combating Violent-Extremism and Insurgency in Nigeria: A Case Study of the Boko Haram Scourge.” PhD Diss., University of Kansas.

Barkindo, Atta. 2013. "Join the Caravan: The Ideology of Political Authority in Islam from Ibn Taymiyya to Boko Haram in North-Eastern Nigeria." Perspectives on Terrorism 7, 3: 30-43.

BBC. 2012. "Nigeria's President Jonathan 'Must Act Over Fuel Scam.” British Broadcasting Company, May 29. http://www.bbc.com/news/world-africa-18238973.

BBC. 2014. "Nigeria's Boko Haram leader Abubakar Shekau in profile.” British Broadcasting Company, May 9. http://www.bbc.com/news/world-africa-18020349.

BBC. 2011. "Nigeria’s Boko Haram Islamists 'Bombed Abuja Police HQ."' British Broadcasting Company, June 17. http://www.bbc.com/news/world-africa-13805688. 
BBC. 2016. "Boko Haram 'Ousted From Sambisa Forest Bastion." British Broadcasting Company, December 24. http://www.bbc.com/news/world-africa-38427462.

BBC. 2015. “Nigeria Boko Haram: Militants 'Technically Defeated' - Buhari.” British Broadcasting Company, December 24. http://www.bbc.com/news/world-africa-35173618.

Bourne, Richard. 2015. Nigeria: A New History of a Turbulent Century. London: Zed Books.

Boyle, Joe. 2009. “Nigeria’s ‘Taliban’ Enigma.” British Broadcasting Company, July 31. http://news.bbc.co.uk/2/hi/africa/8172270.stm.

Brock, Joe. 2011. "Nigerian Islamist Sect Claims Bomb Attack.” Reuters, June 17. http://af.reuters.com/article/topNews/idAFJOE75G0BF20110617?sp=true.

Butler, Judith. 1992. "Contingent Foundations: Feminism and the Question of 'Postmodernism."' In Feminsits Theorize the Political, edited by J. Butler and J. Scott, 3-21. London and New YorkRoutledge.

Campbell, John. 2013. Nigeria: Dancing on the Brink. Lanham: Rowman and Littlefield.

Cavanaugh, William. 2009. The Myth of Religious Violence. New York: Oxford University Press.

CFR (Council on Foreign Relations). 2017. "Nigeria Security Tracker: Mapping Violence in Nigeria." Last modified February 12. http://www.cfr.org/nigeria/nigeria-securitytracker/p29483.

CIA. 2017. "World Factbook: Nigeria." Central Intelligence Agency. Last updated January 12, 2017. https://www.cia.gov/library/publications/the-world-factbook/geos/ni.html.

Corones, Mike. 2015. “Mapping Boko Haram’s Decline in Nigeria.” Reuters, May 5. http://blogs.reuters.com/data-dive/2015/05/05/mapping-boko-harams-decline-in-nigeria.

Douglas, Mary. 2002. Purity and Danger. London and New York: Routledge.

Economist. 2014. "Education in Nigeria: Mixing the Modern and Traditional." July 26. http://www.economist.com/news/middle-east-and-africa/21608809-trying-teach-childrennot-be-extremists-mixing-modern-and.

Economist. 2016. "Another Brutal Attack by Boko Haram Highlights the Weakness of Nigeria's Military." February 5. http://www.economist.com/news/middle-east-and-africa/21690136recent-attack-reflects-badly-military-reforms-boko-back.

Forest, James J.F. 2012. Confronting the Terrorism of Boko Haram in Nigeria. MacDill AFB, Florida: Joint Special Operations University Press.

Gaffey, Conor. 2015. “Who is Sheikh Zakzaky, Nigeria’s Most Powerful Shiite Muslim?” Newsweek, December 16. 
Gartenstein-Ross, Daveed, and Jacob Zenn. 2016. “Boko Haram's Doomed Marriage to the Islamic State." War on the Rocks, August 26. https://warontherocks.com/2016/08/boko-haramsdoomed-marriage-to-the-islamic-state.

Gurr, Ted Robert. 1970. Why Men Rebel. Princeton: Princeton University Press.

Hansen, William, and Umma Aliyu Musa. 2013. "Fanon, the Wretched and Boko Haram." Journal of Asian and African Studies 48, 3: 281-296.

Hill, J.N.C. 2012. Nigeria Since Independence: Forever Fragile? London: Palgrave Macmillan.

Hoffman, Danny. 2011. The War Machines: Young Men and Violence in Sierra Leone and Liberia. Durham: Duke University Press.

Huntington, Samuel P. 1993. “The Clash of Civilizations?” Foreign Affairs 72, 3: 22-49.

Ibrahim, Jibrin. 1991. "Religion and Political Turbulence in Nigeria." The Journal of Modern African Studies 29, 1: 115-136.

ICG (International Crisis Group). 2014. Curbing Violence in Nigeria (II): The Boko Haram Insurgency. Brussels: International Crisis Group. http://www.crisisgroup.org/ /media/Files/africa/ west-africa/nigeria/216-curbing-violence-in-nigeria-ii-the-boko-haram-insurgency.

Idonor, Daniel, and Ndahi Marama. 2011. "Boko Haram Sect Splits.” Vanguard, July 21. http:/ /www.vanguardngr.com/2011/07/boko-haram-sect-splits/

Ikelegbe, Augustine. 2006. "The Economy of Conflict in the Oil Rich Niger Delta Region of Nigeria." African and Asian Studies 5: 23-55.

Ikerionwu, Ikechukwu Daniel. 2014. "The Islamic Resurgence and Boko Haram Insurgency in Nigeria." PhD Diss., University of Massachusetts.

Kashi, David. 2013. "China is Looking to Nigeria for Crude Oil and Has Been Trying to Win Favor With the Nation by Investing in the West African Country." International Business Times, July 12. http:/ / www.ibtimes.com/china-looking-nigeria-crude-oil-has-been-trying-win-favornation-investing-west-african-country.

Kayode, Bodunrin. 2014. "Inside Nigeria’s Sambisa Forest, the Boko Haram Hideout Where Kidnapped Schoolgirls are Believed to be Held." The Guardian, April 29. https://www.theguardian.com/world/2014/apr/29/nigeria-sambisa-forest-boko-haramhideout-kidnapped-school-girls-believed-to-be-held.

Last, Murray. 2012. "From Dissent to Dissidence: The Genesis and Development of Reformist Islamic groups in Northern Nigeria.” NRN Working Paper: no. 5.

Last, Murray. 2005. “Towards a Political History of Youth in Northern Nigeria, 1750-2000.” In Vanguard or V andals: Youth, Politics and Conflict in Africa, edited by Jon Abbink and Ineke van Kessel, 37-54. Leiden: Brill. 
Lanre, Ola. 2017. "Boko Haram Attacks Town Previously Bombed by Nigerian Air Force.” Reuters, January 21. http://www.reuters.com/article/us-nigeria-security-idUSKBN1550RU.

Lewis, Bernard. 1976. "The Return of Islam.” Commentary 61, 1: 39-49.

Liu, Joanne, and Natalie Roberts. 2016. "Why the Children of Nigeria’s Borno State Are Missing." Time. November 7.

Locke, Callum, and Caroline Nevitt, Robin Kwong, Aleksandra Wisniewska, Steve Bernard, Aimee Keane, William Wallis, and Maggie Fick. 2016. “Timeline: Boko Haram's Deadly Evolution.” Financial Times. Last updated January 28. http://ig.ft.com/sites/2015/boko-haram-timeline.

Looney, Robert. 2014. “The Boko Haram Economy.” Foreign Policy, July 15.

Lubeck, Paul. 1999. "The Islamic Revival: Antinomies of Islamic Movements Under Globalization." Center for Global International \& Regional Studies Working Paper Series: WP No. 99-1.

Lubeck, Paul. 2011. “Nigeria: Mapping a Shari’a Restoration Movement.” In Shari'a Politics: Islamic Law and Society in the Modern World, edited by Robert Hefner, 244-279. Bloomington: Indiana University Press.

Lubeck, Paul, Ronnie Lipschutz, and Erik Weeks. 2003. "The Globality of Islam: Sharia as a Nigerian 'Self-Determination' Movement.” Paper presented at the Conference on Globalisation and Self-Determination, London, April 4.

Maiangwa, Benjamin, Ufo Okeke Uzodike, Ayo Whetho, and Hakeem Onapajo. 2012. "Baptism by Fire: Boko Haram and the Reign of Terror in Nigeria." Africa Today 59, 2: 40-57.

Maier, Karl. 2002. This House has Fallen: Nigeria in Crisis. Boulder: Westview Press.

Mamdani, Mahmood. 2005. Good Muslim, Bad Muslim: America, the Cold War, and the Roots of Terror. New York: Random House.

March, Andrew F. 2015. "Political Islam: Theory." Annual Review of Political Science 18: 17.1-17.21. doi: 10.1146/annurev-polisci-082112-141250.

Matfess, Hilary. 2017. “Nigeria’s Suffering Civilians.” Foreign Affairs, January 30.

McGreal, Chris. 2014. "Nigeria Kidnapping: Why Boko Haram is a Top Security Priority for the US." The Guardian, May 9.

Meagher, Kate. 2013. "Informality, Religious Conflict, and Governance in Northern Nigeria: Economic Inclusion in Divided Societies." African Studies Review 56, 3: 209-234.

Murtada, Ahmad. 2013. Boko Haram: Its Beginnings, Principles, and Activities in Nigeria. Kano, Nigeria: Salafimanajh. 
Mustapha, Abdul Raufu. 2014. "Interpreting Islam: Sufis, Salafists, Shi'ites \& Islamists in Northern Nigeria," in Sects and Social Disorder: Muslim Identities \& Conflict in Northern Nigeria, edited by Abdul Raufu Mustapha, 1-17. Suffolk: James Currey.

Nation. 2014. “Timeline of Boko Haram Attacks.” July 24. http:/ / thenationonlineng.net/timelineof-boko-haram-attacks.

NBS. 2012. "Nigeria Poverty Profile 2010.” Abuja: National Bureau of Statistics.

Niworu, Salihu Mohammed. (2013) "Boko Haram Sect: Terrorists Or a Manifestation of the Failed Nigerian State." Journal of Politics and Law 6, 2: 245-250.

Nossiter, Adam. 2014. "Tales of Escapees in Nigeria Add to Worries About Other Kidnapped Girls," New York Times, May 14.

Nossiter, Adam. 2015. "In Nigeria, New Boko Haram Suicide Bomber Tactic: 'It's a Little Girl.”' New York Times, January 10.

Nossiter, Adam. 2011. "Nigerian Group Escalates Violence with Church Attacks.” New York Times, December 25.

Nossiter, Adam and David D. Kirkpatrick. 2014. "Abduction of Girls an Act Not Even Al Qaeda Can Condone.” New York Times, May 7.

NPC (National Population Commission [Nigeria]). 2014. Nigeria Demographic and Health Survey 2013. Rockville, Maryland: National Population Commission and ICF International.

Obaji Jr., Philip. 2017. "Boko Haram Suicide Squads Include Little Boys, Girls, and Now Babies.” The Daily Beast, January 25. http://www.thedailybeast.com/articles/2017/01/25/bokoharam-suicide-squads-include-little-boys-girls-and-now-babies.html.

Odunsi, Wale. 2014. "Former Army Chief Ihejirika is not Boko Haram Sponsor - SSS." Daily Post (Nigeria), September 5. http://dailypost.ng/2014/09/05/former-army-chief-ihejirika-bokoharam-sponsor-sss.

Office of the United States Trade Representative. 2013. "Nigeria." Last accessed June 5, 2015. http://www.ustr.gov/countries-regions/africa/west-africa/nigeria.

Okeowo, Alexis. 2014. "Inside the Vigilante Fight Against Boko Haram.” New York Times, November 5.

Oladipo, Tomi. 2015. “Analysis: Islamic State Strengthens Ties with Boko Haram.” British Broadcasting Company, April 24. http://www.bbc.com/news/world-africa-32435614.

Onapajo, Hakeem. 2012. "Politics for God: Religion, Politics and Conflict in Democratic Nigeria." The Journal of Pan African Studies 4, no. 9 (2012). Pp. 42-59. 
Onuoha, Freedom. 2012. “From Ahlulsunna wal'jama'ah hipa to Jama'atu Ahlissunnah lidda'awati wai Jihad: The Evolutionary Phases of the Boko Haram Sect in Nigeria." Africa Insight 41, 4: 159-175.

Oshikoya, Temitope. 2008. "Nigeria in the Global Economy." Business Economics 43: 31-43.

Osumah, Oarhe. 2013. "Boko Haram Insurgency in Northern Nigeria and the Vicious Cycle of Internal Insecurity.” Small W ars \& Insurgencies 24, 3: 536-561.

Paden, John N. 2005. Muslim Civic Cultures and Conflict Resolution: The Challenge of Democratic Federalism in Nigeria. Washington DC: Brookings Institution Press.

Page, Matthew. 2016. "Five Reasons Washington Should Rethink Selling Warplanes to Nigeria." War on the Rocks, November 8. https://warontherocks.com/2016/11/five-reasonswashington-should-rethink-selling-warplanes-to-nigeria.

Pham, Peter. 2012. “Boko Haram's Evolving Threat.” Africa's Security Brief 30: 1-8.

Preston, Alex. 2014. “Boko Haram: Sons of Anarchy.” GQ, February 4.

Rana, Junaid. 2007. "The Story of Islamophobia." Souls 9, 2: 148-161.

Rufai, Saheed. 2011. "The Interplay of Power and Religion in Nigeria from Colonization to Democratization." World Journal of Islamic History and Civilization 1, 3: 168-177.

Sampson, Isaac Terwase. "Religious Violence in Nigeria: Causal Diagnoses and Strategic Recommendations to the State and Religious Communities." African Journal on Conflict Resolution 12, 1: 103-134.

Searcey, Dionne. 2017. “Nigerian Jet Mistakenly Bombs Refugee Camp, Killing Scores.” New York Times, January 17.

Searcey, Dionne. 2016a. "Boko Haram Turns Female Captives Into Terrorists.” New York Times, April 7.

Searcey, Dionne. 2016b. "Boko Haram Falls Victim to a Food Crisis it Created." New York Times, March 4.

Searcey, Dionne. 2016c. "Nigeria is Freeing Children From Boko Haram, Then Locking Them Up." New York Times, August 18.

Searcey, Dionne, and Eric Schmitt. 2016. "Boko Haram May Have a New Leader, ISIS Magazine Suggests." New York Times, August 3.

Sesay, Isha, and Stephanie Busari. 2016. "Freed Chibok Girls Return Home for Joyful Christmas." CNN, December 28. http://www.cnn.com/2016/12/26/africa/chibok-girls-nigeriajourney. 
Sharma, Ruchir. 2012. Breakout Nations. New York: Norton.

Smith, J.Z. 1978. Map is Not Territory: Studies in the Histories of Religions. Chicago: University of Chicago Press.

Stanford University. 2016. "Mapping Militant Organizations: Boko Haram.” Last modified August 26. http://web.stanford.edu/group/mappingmilitants/cgi-bin/groups/view/ 553?highlight=boko+haram.

Taiwo, Fowoyo Joseph. 2014. "Transforming the Almajiri Education for the Benefit of the Nigerian Society.” International Letters of Social and Humanistic Sciences 08: 244-251.

Tibi, Bassam. 2012. Islamism and Islam. New Haven: Yale University Press.

Topol, Sarah A. 2014. "If We Run and They Kill Us So Be It. But We Have to Run Now.” Medium, October 14. https://medium.com/matter/if-we-run-and-they-kill-us-so-be-it-but-we-haveto-run-now-ad48d0b28994\#.bz2zuutm2.

Tukur, Sani. 2014. "Ex-gov Sheriff, Accused of Sponsoring Boko Haram, Ready to Face Justice." Premium Times, September 3. https://www.premiumtimesng.com/headlines/167706-ex-govsheriff-accused-of-sponsoring-boko-haram-ready-to-face-justice.html.

Umar, Gunu, and Kilishi A. Abdulhakeem. 2010. "Oil Price Shocks and the Nigeria Economy." International Journal of Business and Management 5: 39-49.

Umar, Muhammad Sani. 2012. "The Popular Discourses of Salafi Radicalism and Salafi CounterRadicalism in Nigeria: A Case Study of Boko Haram." Journal of Religion in Africa 42, 2: 118144.

UN. 2016. “Nigeria’s Humanitarian Crisis 'Can No Longer Be Ignored,' UN Says, Launching \$1 Billion Appeal.” UN News Centre, December 2. http://www.un.org/apps/news/story.asp? NewsID=55702\#.WKhz97YrJE6.

UNDP. 2013. "The Rise of the South: Human Progress in a Diverse World." Human Development Report. Last accessed January 27, 2014. http://hdrstats.undp.org/images/explanations/ NGA.pdf.

UNDP. 2015. Millennium Development Goals End-Point Report. Abuja: OSSAP-MDGs.

VOA. 2016. "New Video: Boko Haram Leader Says Group is 'Safe' and 'Not Crushed." Voice of America, December 29. http://www.voanews.com/a/video-boko-haram-leader-says-groupsafe-not-crushed/3655690.html.

Wakili, Haruna. 2009. "Islam and the Political Arena in Nigeria: The Ulama and the 2007 Elections." Institute for the Study of Islamic Thought in Africa (ISITA) Working Paper Series: WP no. 09-004. 
Wallace, Paul, and Emele Onu. 2016. "Free-Float Flounders as Nigerian Naira Hits Black Market Low.” Bloomberg Markets, October 6. https://www.bloomberg.com/news/articles/2016-1006/free-float-flounders-as-nigeria-s-naira-hits-black-market-record.

Withnall, Adam. 2016. "Boko Haram Descends Into In-Fighting as Reports Emerge of Deadly Clashes Between Rival Islamist Factions." The Independent. Accessed February 17, 2017. http://www.independent.co.uk/news/world/africa/boko-haram-descends-into-in-fightingas-reports-emerge-of-deadly-clashes-between-rival-islamist-a $7231726 . h t m l$.

World DataBank. 2014. http://www.worldbank.org/en/country. Last accessed September 23, 2016.

WorldPop. 2013. “Mapping Poverty.” Last accessed February 17, 2017. http://www.worldpop.org.uk/resources/images/pov2.jpg.

Zenn, Jacob. 2012. Northern Nigeria's Boko Haram: The Prize in al-Qaeda's African Strategy. Washington DC: The Jamestown Foundation. 